Historic, Archive Document

Do not assume content reflects current scientific knowledge, policies, or practices. 
$-$ 


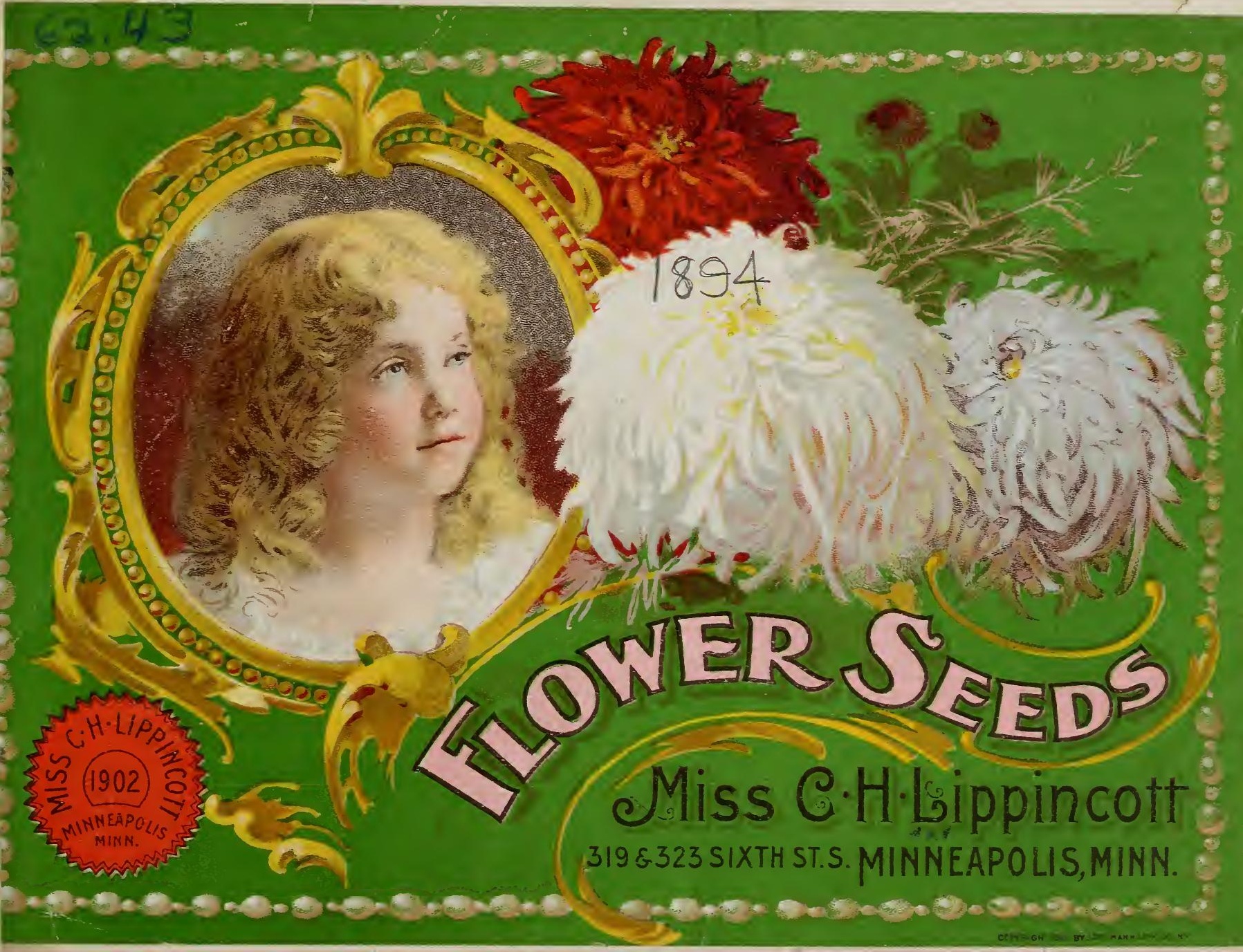


THE LARGEST EXCLUSIVE FLOWER AND SEED HOUSE IN THE WORLD.
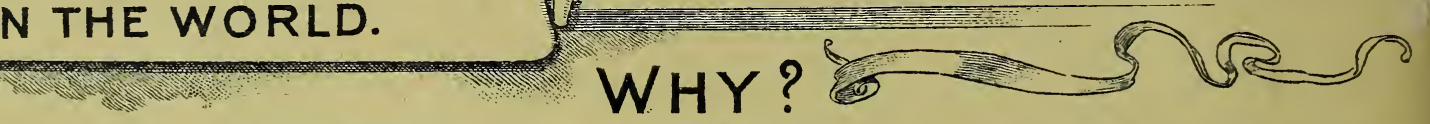

TEN YEARS SUCCESSFUL BUSINE!

Because my Flower Seeds are fresh, strictly pure and of the finest quality; Such as will produce the most perfect flowers and give satisfaction to my patrons so they will remain permanent customers.

THOSE who receive a copy of this book have either sent an order the past season for my flower seeds, or their names have been sen me by some friend who said they were interested in beautiful flowers. If you wish copies sent to friends who have never plant my seeds, I will do so with pleasure, on receipt of their address, FREE of charge.

FREE PREPIUN 30 CENTS' worth of seeds extra allowed on all orders amo.nting to ONE DOLLAR; i5 CENTS' worth selected all orders amounting to 50 CENTS. This liberal premium is the same as 30 per cent. discount, but must This Premium is allowed on seeds in packets and ounce only.

HOW TO REPHT MONEY Always send money by one of the following methods : Post Office Order, Express Mone safe-I especially Order, Registered Letter or Draft, providing to remit money in this way, and I will allow you to select seeds.to the cost of the Money way of remitting amount; and when you do, two-cent denomination preferred. And Register them. If money is sent any other wa' than specified above it is at the risk of the sender. Our Canadian patrons need have no hesitancy about remitting Canadian stam! as we receive them the same as cash - at full face value.

DSTP ID All seeds sent postpaid and safe arrival guarantoed; all orders received to the amount of $\$ 1.50$ and upwards w PO IP ID. be forwarded by Registered Mail to purchaser's address, which costs me 8 . cents extra, but insures the safe arri of your seeds. Please sign your name and full address on each and every letter you send.

Quantity of Seed in a Packet. Customers will please note I state number of seeds in a packet, which will enat number of packages required. Full Count Guaranteed. No less quantity than a package can be sold.

FLORAL CULTURE. Containing full cultural directions and points how to grow flowers from seeds, mailed free with ever PLEASE - Do not forget to sign your

I DO NOT DEAL IN PLANTS, BULBS OR VEGETABLE SEEDS OF ANY் DESCRIPTION.

All orders for Flower Seeds should be addressed to

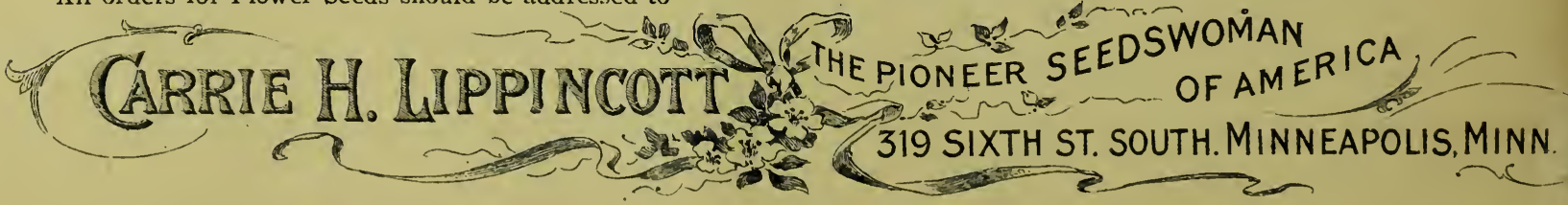




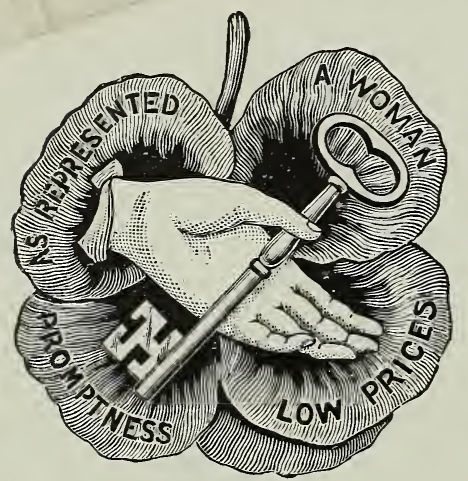

\section{Nothing Succeeds Like Success!}

Over Seventy Thousand (70,000) customers the past season (actual cash buyers). WHY? Because the people have confidence in me. They like the way I do business. They like my unique catalogue, devoted exclusively to Flower seeds. They like prompt service. They like the best seeds. They love beautiful flowers, and last, but not least, they like reasonable prices by a woman.

This is the Key to My Success: Sound Reasons, Progressive Institutions Bear Abundant Fruit.
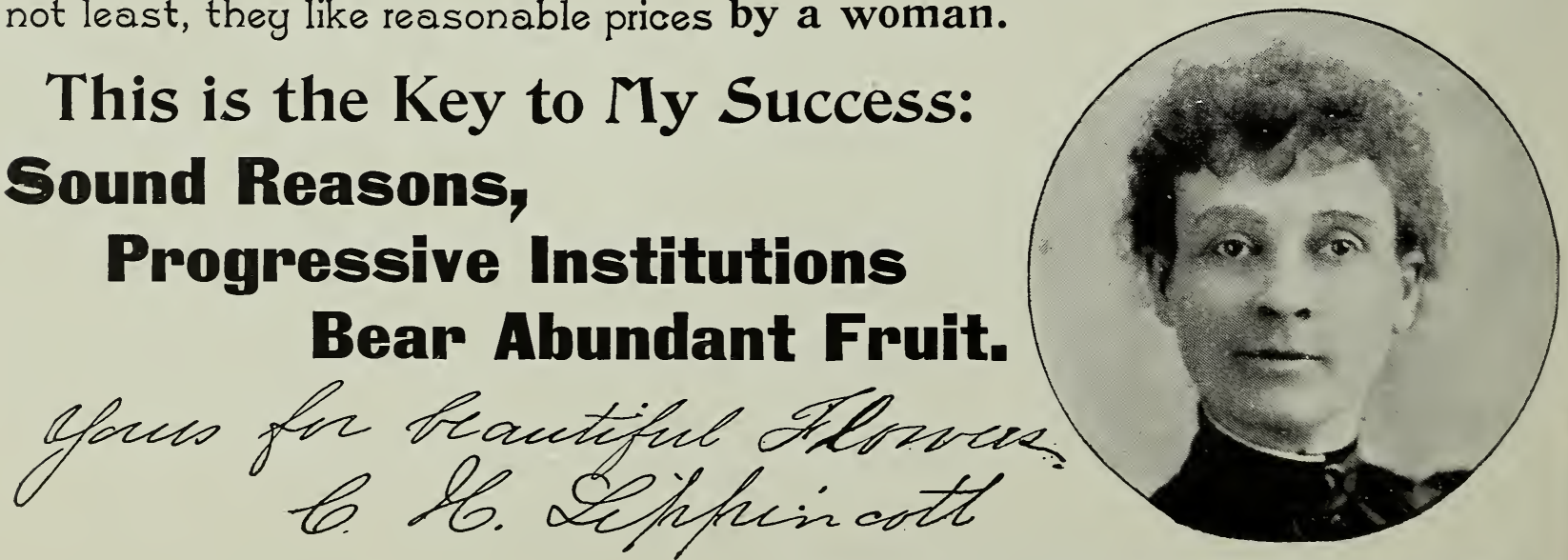

319 and 323 Sixth Street S., MINNEAPOLIS, MINN. 

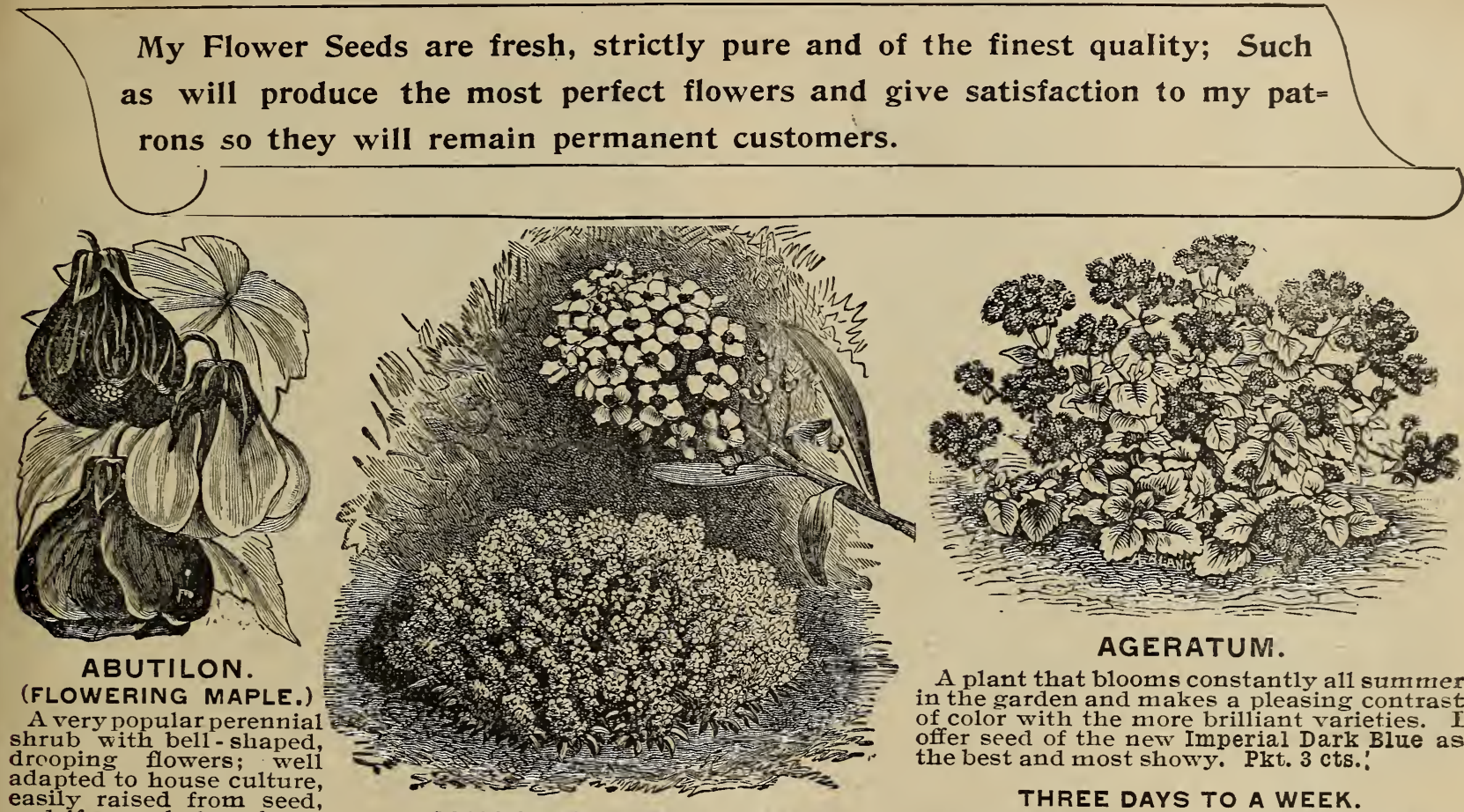

\section{AGERATUM.}

A plant that blooms constantly all summer in the garden and makes a pleasing contrast of color with the more brilliant varieties. I offer seed of the new Imperial Dark Blue as the best and most showy. Pkt. 3 cts.'

THREE DAYS TO A WEEK.

ALYSSUM, LITTLE GEM.

The plants begin to flower quite young, and sonn become one mass of white, remaining in full bloom from spring to fall-each plant being densely studded with beautiful miniature spikes of deliciously fragrant flowers. Pkt. $4 \mathrm{C}$

$\$ 50.00$ IN CASH for the largest Royal Show Pansies. See page 31 .

\section{ALYSSUM, SWEET.}

Its pure white, fra grant flowers are produced from early spring till killed by frost, very useful in all kinds of boquets. Pkt. 3 cts.
Antonia Frank, Jr., Willis, Texas, writes I was very much pleased with the Bargain Collection, the seed coming up in from three days to a week.

\subsubsection{F FPAE that every or-} Seeds in Packets, to the amount of $50 \mathrm{cts}$., is entitled to one good, strong, healthy Yeteor Rose: a dollar order, one Testout Rnse; or for a $\$ 1.30$ order, one of each variety FREE. 

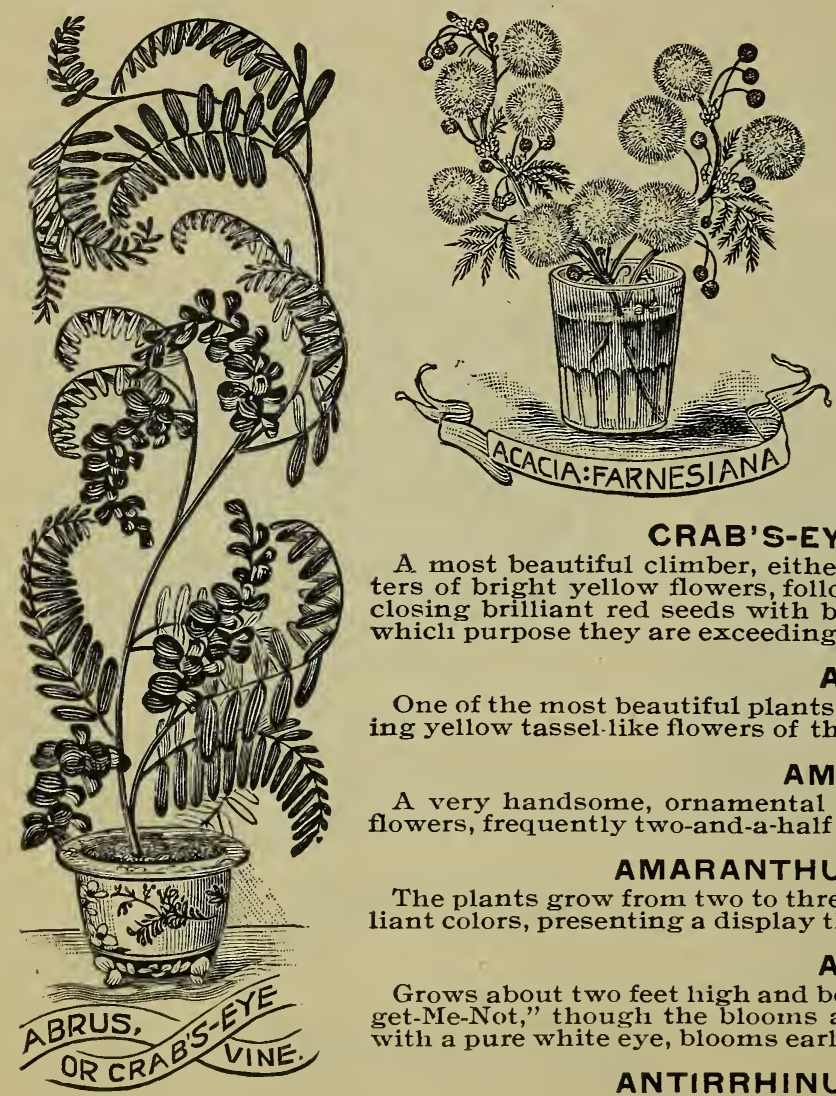

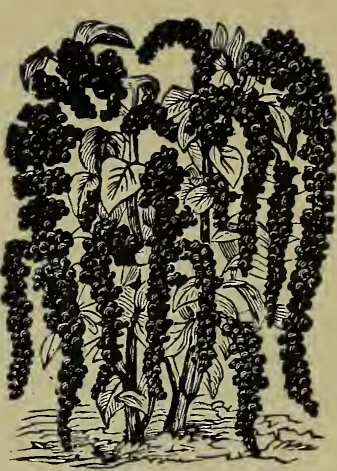

Amaranthus Gibosus.

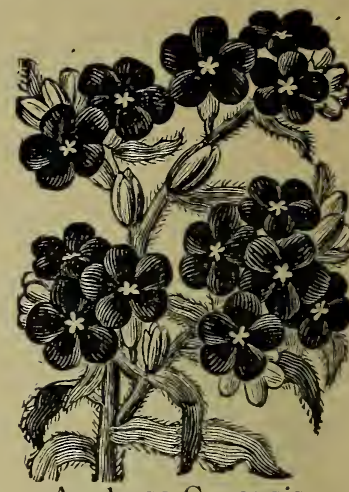

Anchusa Capensis.

CRAB'S-EYE VINE. (ABRUS PRECATORIUS.)

A most beautiful climber, either for pot culture or the open ground in summer; bears clusters of bright yellow flowers, followed by bunches of pods which, when dry, burst open, disclosing brilliant red seeds with black eyes, used for making beads and other ornaments, for whicli purpose they are exceedingly pretty. Pkt. 6 cts.

\section{ACACIA, FARNESIANA.}

One of the most beautiful plants in cultivation, having delicate fern-like foliage and charming yellow tassel-like flowers of the most delicious fragrance. Pkt. $6 \mathrm{cts}$.

\section{AMARANTHUS, GIBOSUS.}

A very handsome, ornamental foliage plant with long drooping panicles of purplish-red flowers, frequently two-and-a-half feet in length. Pkt. 3 cts.

\section{AMARANTHUS SPLENDENS, (RAINBOW PLANT.)}

The plants grow from two to three feet liigh, and in the fall the leaves turn to the most bril. liant colors, presenting a display that few plants can equal. Pkt. 6 cts.

\section{ANCHUSA CAPENSIS.}

Grows about two feet high and bears a profusion of the most lovely flowers, similar to "Forget-Me-Not," though the blooms a re larger and of a finer color, being cf a clear, brilliant blue with a pure white eye, blooms early and continues all summer. Pkt. 3 cts.

ANTIRRHINUM, TOM THUMB, (SNAPDRAGON.)

The best of all the Antirrhinums, very dwarf, growing only eight inches higli, thickly studded with beautiful spikes of gay-colored flowers: orange, scarlet, yellow, rose-white, maroon, striped, etc. Pkt. 4 cts. 


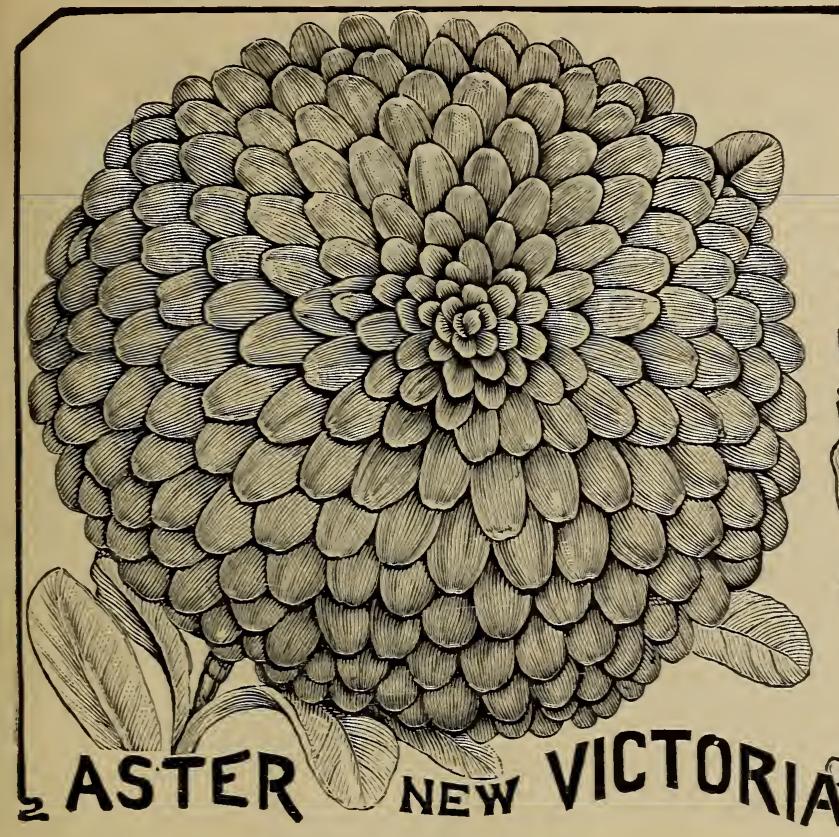

VICTORIA ASTERS.

Magnificent flowers, massive and showy, with regular overlapping petals clear to the centre. The flowers measure four inches and over across, and are of rich and varied colors. The plants grow very evenly, pyramidal in form, about 18 inches high, and carry from twenty-five to forty flowers. Over twenty colors; mixed. Pkt. 6 cts.

VICTORIA-snow white, Pkt. $8 \mathrm{cts}$.

VICTORIA-bright pink, Pkt. 6 cts.

VICTORIA-dark crimson, Pkt. $6 \mathrm{cts}$.

ASTER-finest mixed of all the best varieties, Pkt. $8 \mathrm{cts}$.

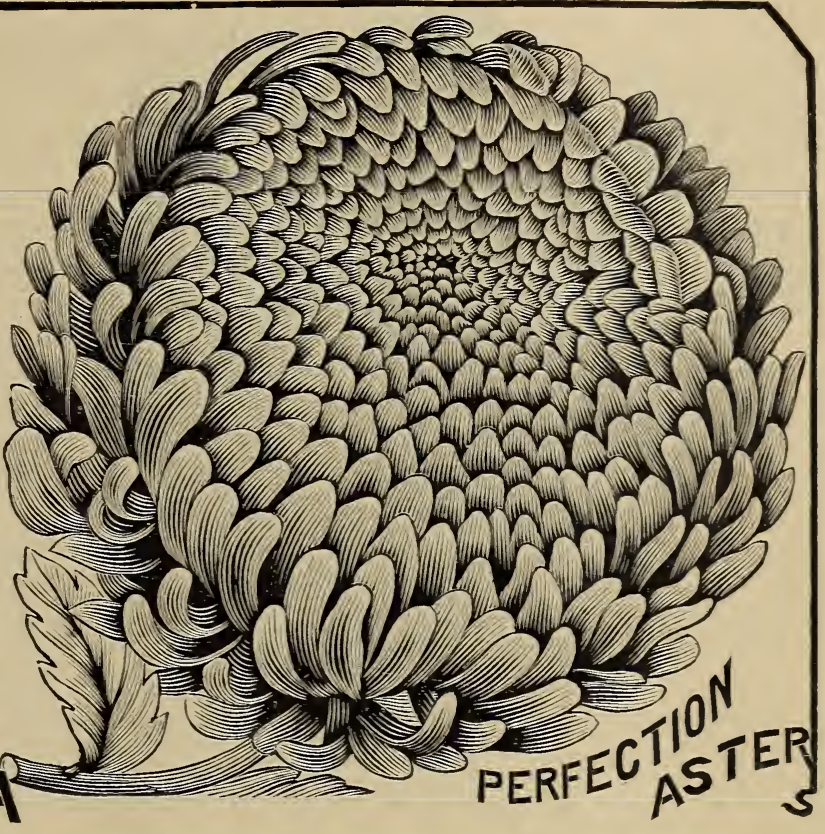

TRUFFAUT'S PAONY-FLOWERED PERFECTION ASTERS.

One of the most perfect and deservedly one of the most popular of all asters; very double, large and beautiful flowers, with incurved petals; height 18 inches to 2 feet; nearly thirty distinct colors mixed. Pkt. 6 cts.

PERFECTION-snow white, Pkt. $8 \mathrm{cts}$.

PERFECTION-pink ball, Pkt. $7 \mathrm{cts}$.

PERFECTION-crimson ball, Pkt. $7 \mathrm{cts}$. 


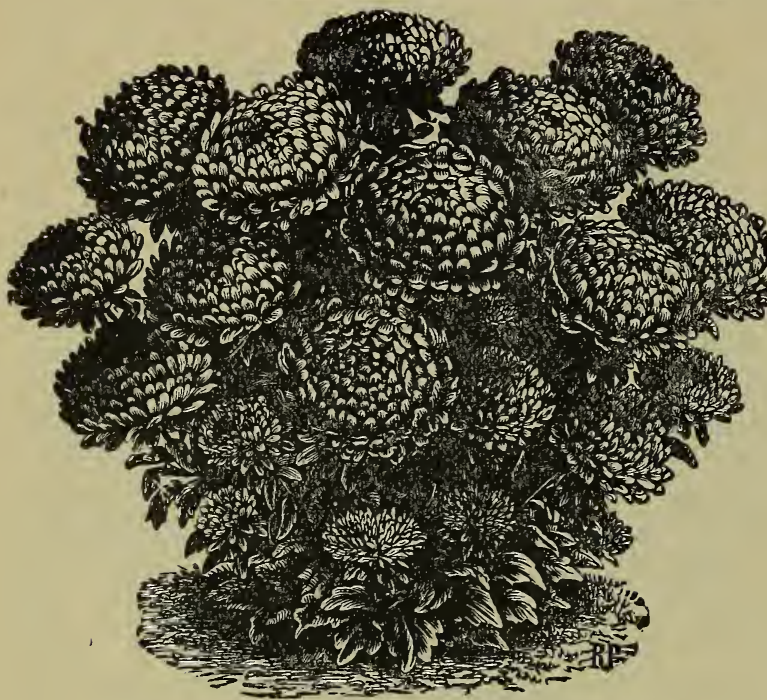

NEW SCARLET TRIUMPH ASTER.

The most charming of all dwarf Scarlet Asters, growing only about 8 inches high and covered with large, handsome, perfectly formed flowers which measure fronı two and a half to three inches across; of the paeony form, all the petals being beautifully incurved. The color is rich and brilliant; when beginning to bloom it is a pure scarlet, but when in full bloom it changes to a magnificent Satiny Scarlet. Pkt. 8 cts.

\section{BALSAMS WORTH A DOLLAR.}

Mattie McDonnell, Austin, Texas, writes:-I tried your Bargain Collection last spring and was just delighted with it. The Balsams alone were worth a dollar.

\section{LOVELY PANSIES.}

Mrs. Dr. Sheeler, Devon, Kans., Writes:-I raised beautifui flowers from the seeds bought of you last year-the Pansies are lovely.
No flower is more popular than the Aster, and few have held so high a place in popular esteem for so many years, and is still growing in favor. For an autumn show of flowers we have not its equal.

NEW QUEEN ASTER.

(See front cover)

Very dwarf bushy plants, growing from 10 to 12 inches high branching free$1 y, m a k i n g a$ dense, compact bush-excellent for pot culture as we 11 as for bed d ing. The flowers are of extraordinary size perfectly double and resemble the finest Victoria Asters in form. I cannot say too much in praise of this new strain, as no other variety can surpass it. Finest Mixed. pkt. 6 cts.

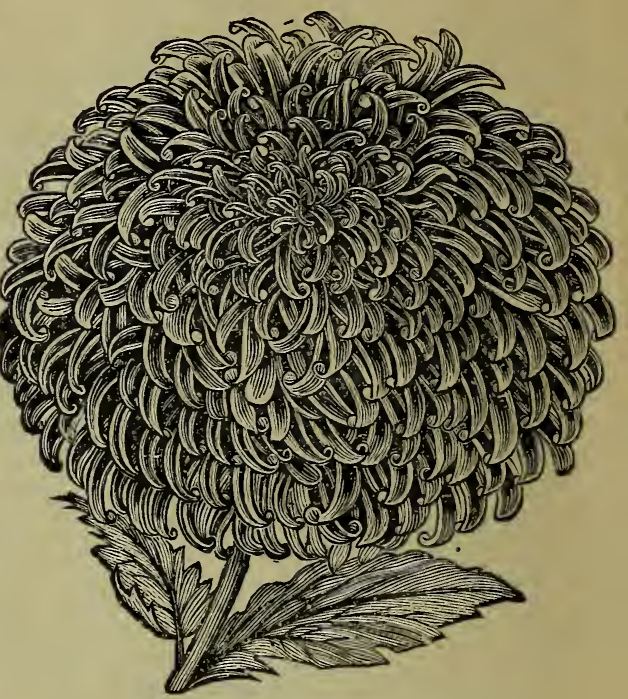

NEW COMET ASTER.

The plants of this new variety are perfectly true in cliaracter, growing 12 to 15 inclies hioh, forming fine, regular pyramids and covered with laro double flowers, as shown in the illustration. The flowers measure from $3^{1 / 2}$ to $4^{1 / 2}$ inches in diameter, resembling in sliape and artistically curved and twisted petals, the finest Chinese Chrysanthemums. Mixed, Pkt. $8 \mathrm{cts}$.

COMET ASTER-pure white, Pkt. $10 \mathrm{cts}$.

COMET ASTER-bright rose, Pkt. $8 \mathrm{cts}$.

A GRAND SIGHT.

Miss Ila Caldwell, Oakton, Ky., writes: My bed of Phlox was a grand sight, so many different colors and markings. 


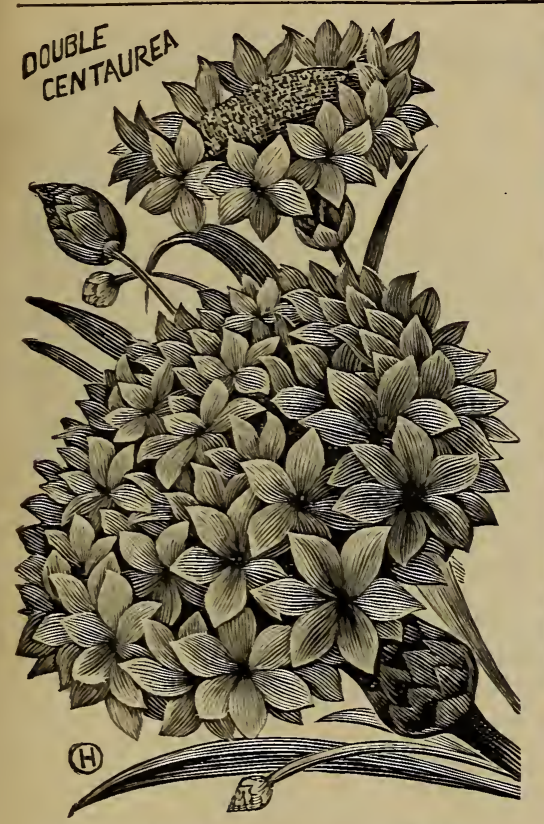

\section{BACHELOR'S BUTTON,} DOUBLE.

It has been so perfected that fully 80 per cent. of the flowers are double and semi-double; they are also increased in size and present many bright colors and distinct markings which have been hitherto unknown in this old-fashioned favorite flower. Pkt. 4 cts.

\section{BACHELOR'S BUTTON, SINGLE.}

Mixed, including dark and light blue, purple, pink, rose, white, etc. Pkt. 3 cts.

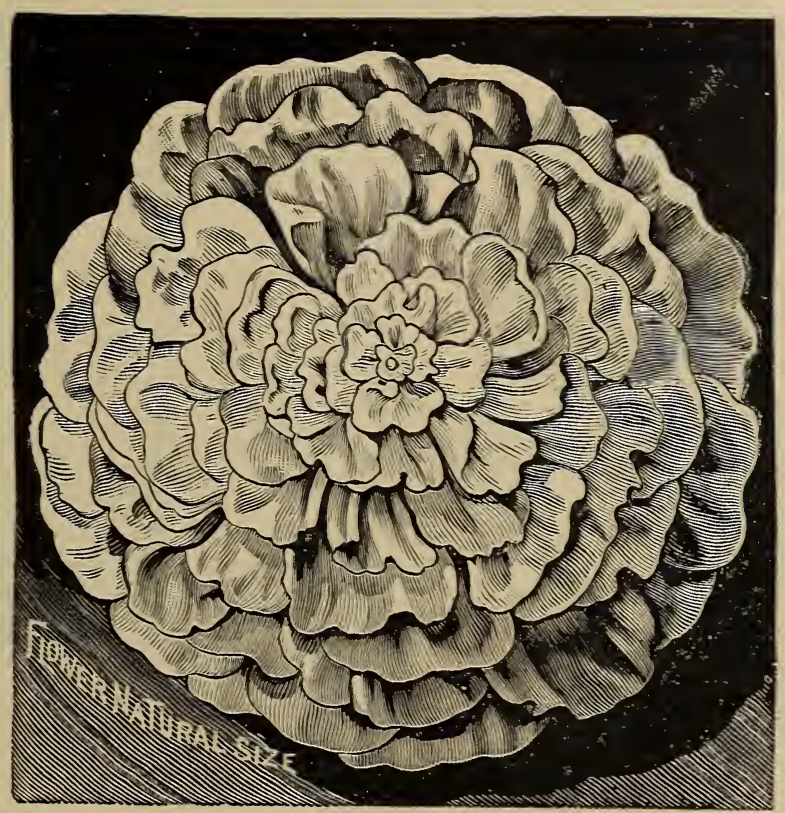

\section{DEFIANCE BALSAM. \\ (LADY SLIPPER.)}

The most perfect in form and largest double flowered Balsam yet developed, and by careful growth and selection has attained a standard that will be found hard to improve. The mixture, which I offer, is composed in nearly equal proportions of 8 colors: Rose, Rose IV hite Spotted, Pink, Scarlet, White Tinted Violet, White Spotted, Scarlet W' ite Spotted and Purple; each having been grown separately. Pkt. $6 \mathrm{cts}$.

BALSAM-good mixed, Pkt. 3 cts.

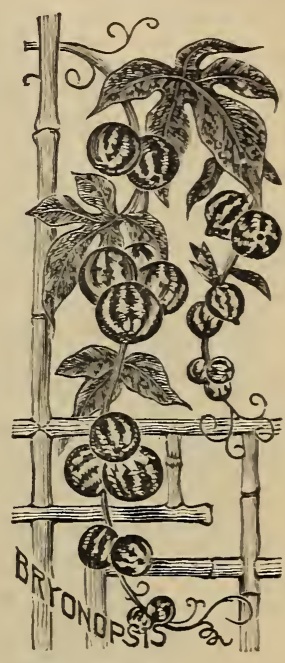

\section{BRYONIA,}

LACINIOSA.

A beautiful climbing annual of rapid growth and easy culture with handsome cut-leaved foliage bearing attractive green fruits, which change in color as the season adrances, to briglit scarlet striped with white. Pkt. 4 cts.

WERE A SUCCESS.

Mrs. R. H. Leigh, Dunseitin, N. Dak., Writes:The seeds I prirchased from you last year were a success. 


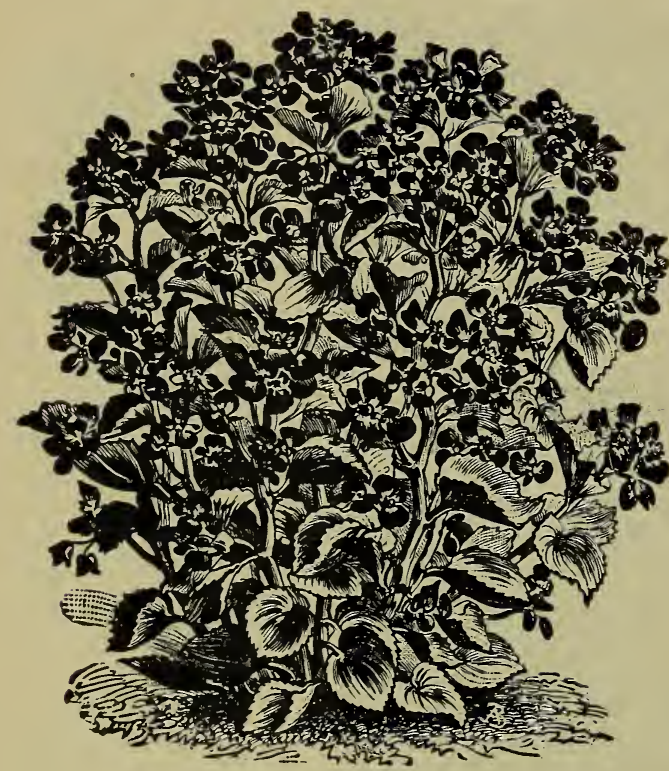

BEGONIA VERNON.

One of the most satisfactory pot plants for the house; and a popular bedding plant for the garden or lawn. It blooms with the greatest profusion throughout the summer. Flowers a brilliant orange carmine with bright yellow centers, and the foliage a glossy red. Pkt. 6 cts.

BEGONIA REX-mixed(ornamental leaved varieties), Pkt. $12 \mathrm{cts}$

BEGONIA - Tuberous Rooted, single mixed. Seed saved from finest colors. Pkt. $12 \mathrm{cts}$.

BEGONIA - Tuberous Rooted, double mixed, from the finest and best colors. Pkt. $18 \mathrm{cts}$.

\section{MORE THAN} ENOUGH.

Mrs. John Haug 719 W. Main St. Norristown, $\mathrm{Pa}$. writes:-The seeds you sent me last spring were perfectly sat is a ctory and there was more than enough for $m y$ little garden. I wish you suc cess in your undertaking and it looks to me as though you were going to have it.

\section{MUCH} SURPRISED. Mrs. Ella M. Clymer, Fricks Pa., writes:-I was ind e ed surprised at the seeds when theycanie, and again at $t h \mathrm{e}$ flowers I had during the summer.

TRUE TO

NAME.

Mrs. Thos. W. Johnson, Paisley,ore., writes The seed which I purchased from you last year was just splendid,every one came up and was true to name.

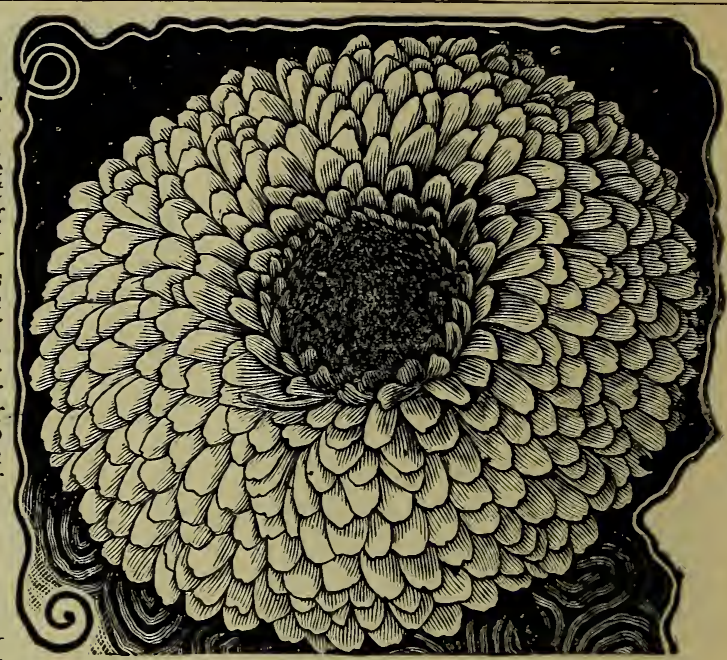

CALENDUla, Double Yellow.

Flowers extra large and very double, color, bright golden yellow. From seed sown in the open ground it comes into flower early, and blooms p

CALENDULA, DOUBLE WHITE.

Similar to the yellow except in color, which is pure white. It is equally as free blooming, and the fine double flowers are very showy. Pkt. 4 cts.

\section{ALL DID WELL.}

Mrs. Effie McCormick, Furley, Kas., writes:-The seeds received from you last season gave satisfaction, everykind you sent did well-such large fragrant Petunias and such great beds of Alyssum, Pinks and Pansies.

\section{SPLENDID SUCCESS.}

Mrs. O. H Curtis, 2116 Locust St, Omaha, Neb. writes:-Last year I tried your seeds and had splendid success. 


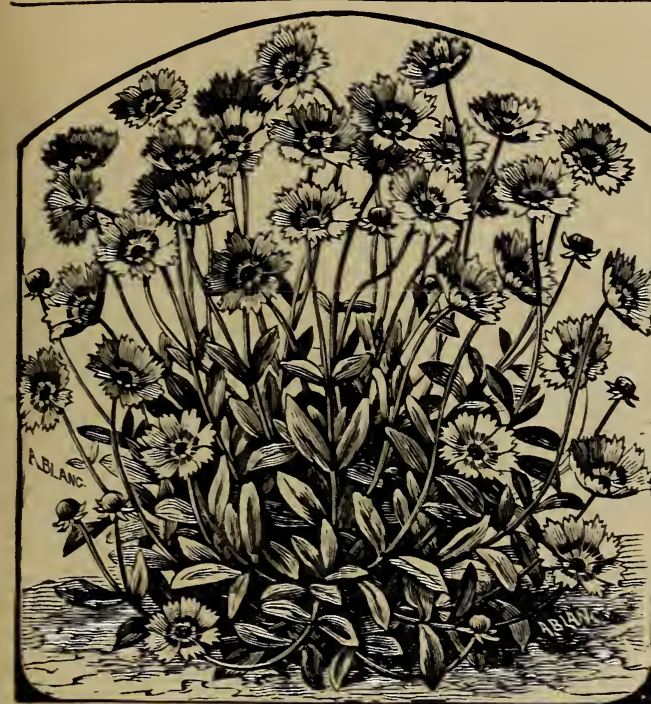

CALLIOPSIS OR COREOPSIS.

Very handsome and showy plants of the easiest culture; require no care and thrive in any garden. Produce flowers in nearly every shade of yellow, orange, crimson, red and brown. It is one of those flowers which will grow in any situation and always be greatly admired. Irixed Colors, Pkt. $3 \mathrm{cts}$.

\section{THE NEIGHBORS' CHICKENS.}

Mrs. E. Duryee, Curtisville, Mass., writes : - Your seeds last year did very good for this climate, but between the neighbors chickens and cold nights I did not get as much pleasure from my garden as $I$ ought.

\section{WONDERFULLY CHEAP.}

Miss E. C. Garver, 278 E. Washington St., Chambersburg Pa., Writes -I consider your Seeds very reliable, and wonderfully cheap.

\section{GAVE ENTIRE}

SATISFACTION.

Mrs. J. Kyle Montague, Christiansburg, Va., writes:-I received some of your seeds last spring, which in every respect gave entire satisfaction, and I must say they are so beautifully sent out - that alone would be an attraction, beside the good quality of the seed.

TILL CHRISTMAS DAY.

Mrs. A. V. Germany Centreville, Miss., writes: From one paper of Sweet Alyssum by transplanting, I had quantities of bunches in the garden in constant bloom from earlyspring till Christmas day. $M Y$ Mignonette also was exceptionally fine.

THE FINEST BALSAMS.

Mrs. Iizzie Childs, salem, N. H. writes:I was much pleased with the seeds you sent me last year. especially the Balsams; they were the finest $I$ ever saw. $I$ wish you the success you deserve.

PINKS WERE LOVELY

Mrs. C. H. B a r nes, North Granby, Conn., writes:-I am very much pleased with rour Seeds, the Pinks were lovely.

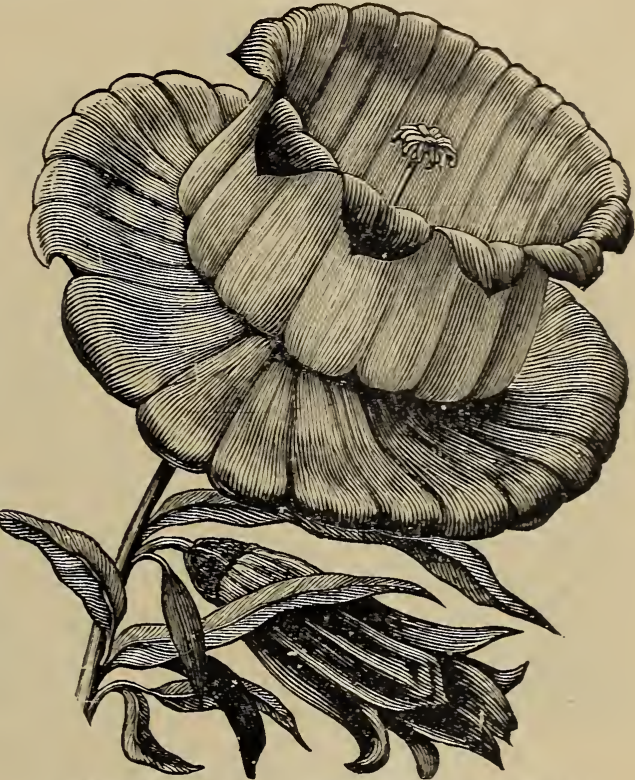

CAMPANULA (CANTERBURY BELLS).

Well known popular perennials, producing bell-shaped flowers of many different colors very freely throughout the summer. SINGLE MIXED, Pkt. 3 cts.; DOUBLE MIXED, Pkt. $4 \mathrm{c}$. NUTE.-The seed saved from double flowers will always produce some single flowers, no matter how careful the selection.

\section{CAMPANULA, GARGANICA.}

A charming miniature trailing Bell flower, with light blue flowers. A splendid plant for hanging baskets or rockery. Pkt. 8 cts. FOUND THEM GOOD.

Mrs. Mary Slipper, Liberty, Ill., writes: Tried your seeds last year; found them good. 


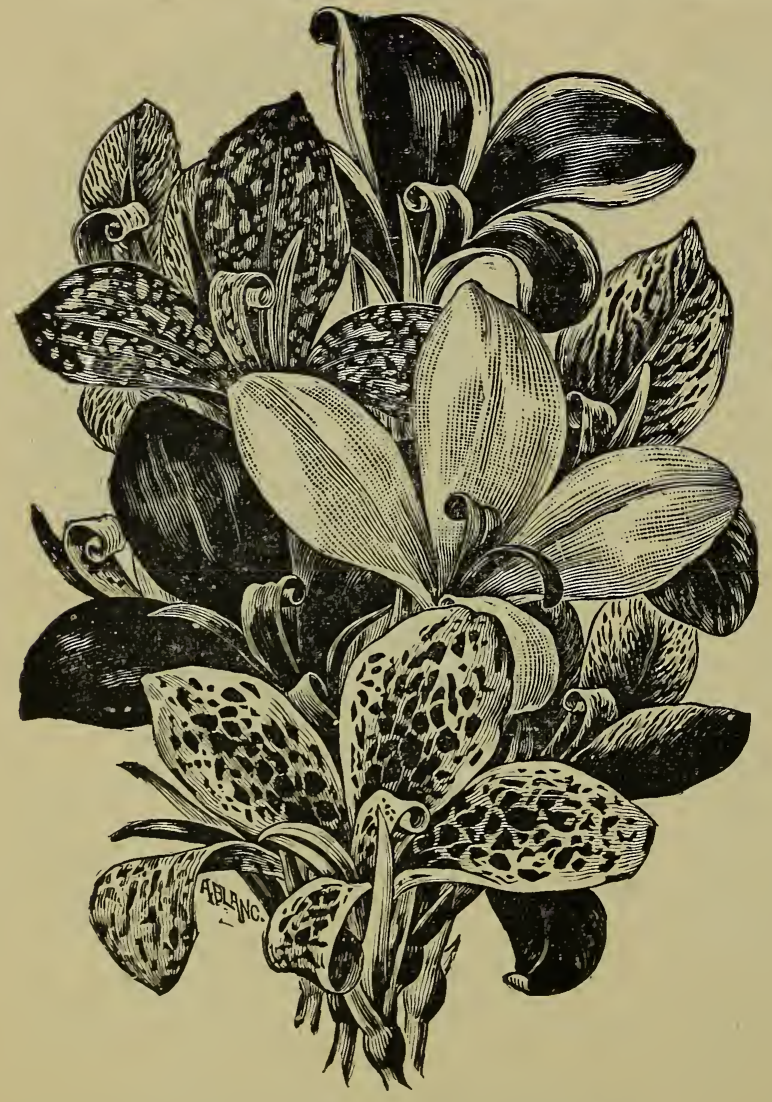

CROZY'S NEW DWARF CANNAS.

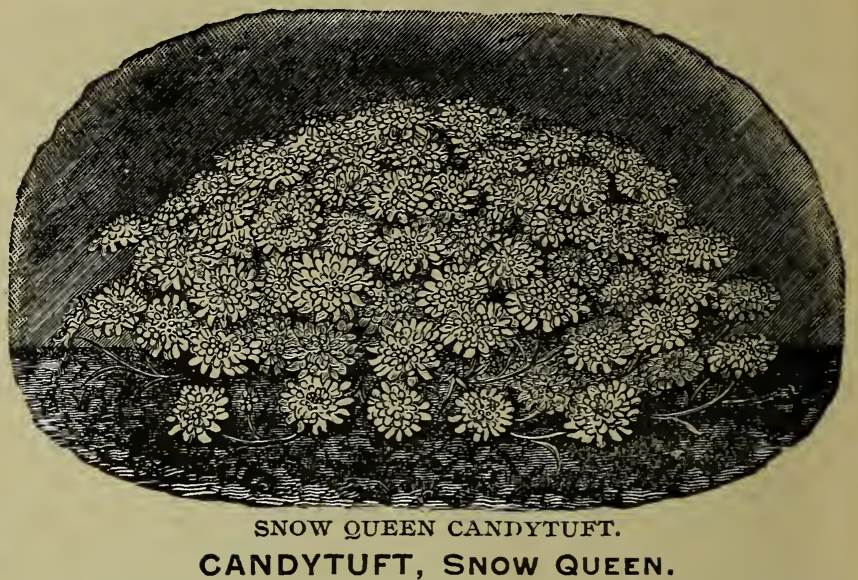

A valuable and distinct species of great beauty. It is an annual variety and grows very rapidly, quickly coming into bloom, remaining in full flower for about three months. It bears but little foliage, and the mass of white produced makes it useful for borders. Pkt. 6 cts.

CANDYTUFT-mixed all colors, Pkt. $3 \mathrm{cts}$.

CROZY'S NEW DWARF CANNAS.

One of the most popular of bedding plants, while even single specimens are most attractive in the garden. They will bloom the first year from seed, if you soak them in boiling water over night; sow singly in small pots as soon as convenient and grow as rapidly as possible. The roots can be kept in the cellar over winter and each clump will give six to eight good roots for planting out the following spring. Pkt. $4 \mathrm{cts}$.

CANNA-old type, good mixed, Pkt. 3 cts.

\section{A PRETTY GARDEN.}

Mrs. B. F. Hammond, Cliff Island, Portland, Me., writes - T had a pretty garden last season from the seeds $I$ bought of you.

ROSES given away FREE on orders for flower SEEDS IN PACKETS. An order for 50 cents, Rose; an order for $\$ 1.30$, secures one of each variety. 


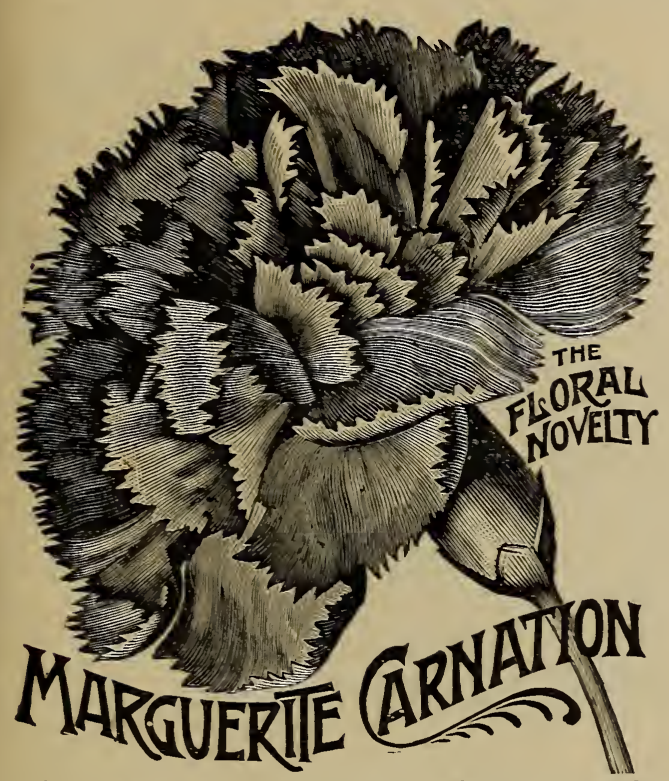

A magnificent new class of Carnations that will bloom in four months after sowing the seed. They are without exception the most abundant bloomers of all the "pinks." The flowers are of brilliant colors, ranging through many beautiful shades of reds, pinks, white, variegated, etc. It is a most raluable acquisition, as Carnation flowers can be had all summer and winter if consecutive sowings are made. Pkt. 6 cts.

CARNATION-German Double Nixed, Pkt, $6 \mathrm{c}$. CARNATION-Ex. fine Double Mixed, Pkt. 12c.

\section{EVERY SEED GREW.}

Miss Ida Schmidlin, 136 Bridge St., East Toledo, 0., writes:- We ordered your Bargain Collection last year and was very much pleased with it. Think that every seed grew.

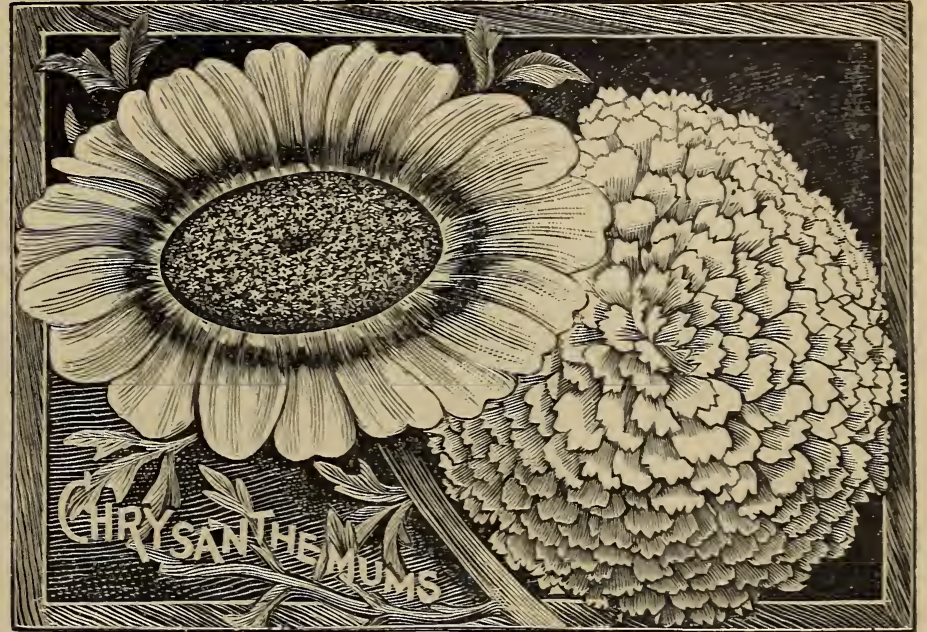

CHRYSANTHEMUM, OR (FRENCH MARGUERITES).

Annual varieties much grown for cut flowers. The plants grow 12 to 18 inches high and produce on long stems beautiful large tlowers of many bright colors. They flower all summer in the garden and make elegant pot plants for winter flowering. Pkt. 3 cts.

CHRYSANTHEMUM, (INODORUM PLENISSIMUM).

Although a perennial, it flowers abundantly the first year from seed, each plant producing hundreds of beautiful perfectly double snow white flowers; unsurpassed for bouquets. It remains in bloom all summer, and is in all respects one of the handsomest and most valuable of flowers. Pkt. 6 cts.

\section{CHRYSANTHEMUM, FANCY PERENNIAL.}

From the best Incurved, Pompone, Japanese, Chinese and Anemone-flowered rarieties. Seeds sown in the hot-bed in February or Iarch, or even April, will give plants that will bloom in August or September. Pkt. 12 cts.

SPLENDID FLOWERS.

Mrs. A. H. Wells, Elkader, Iowa, writes:-I had splended flowers last year from the Seed I received from you. 


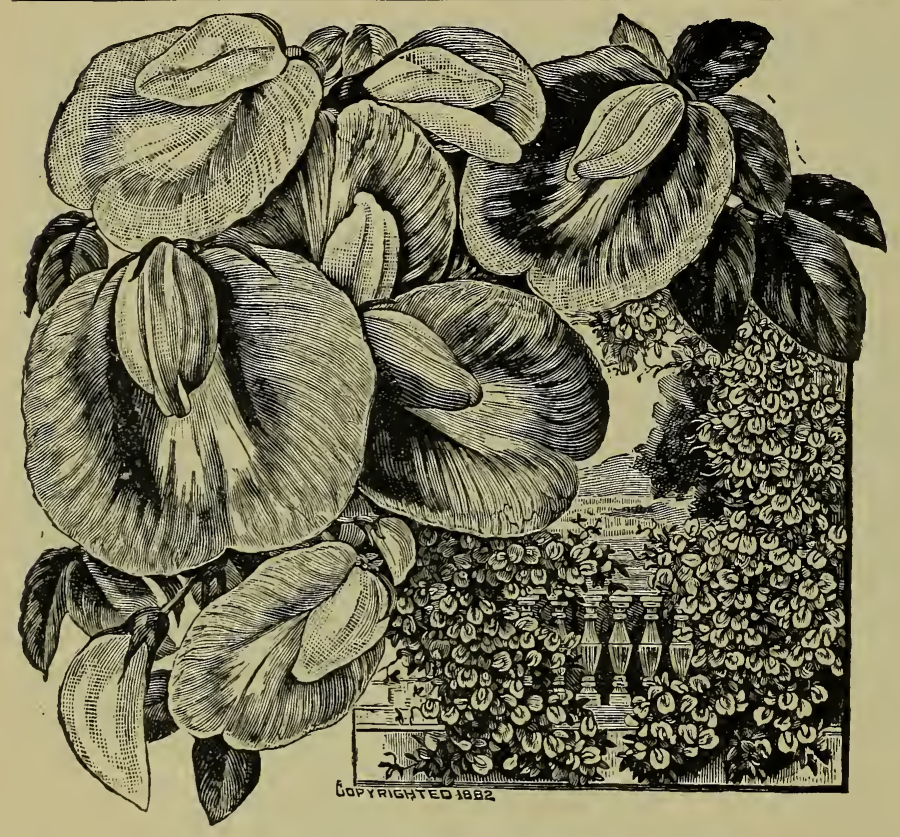

CENTROSEMA GRANDIFLORA.

A hardy perennial vine which will bloom in June or July from seed sown in April, and bears in the greatest profusion inverted peashaped flowers, from $1 \frac{1 / 2}{2}$ to $2 \frac{1}{2}$ inches in diameter, ranging in color from a rosy violet to a reddish purple, with a broad feathered white marking through the center, while the large buds and back of the flowers are pure white, making it appear as if one plant bore many different colored flowers at one time. Pkt. 6 cts.

\section{TRIED AND PROVED.}

Mrs. Ida E. Ham, Hartland, Maine, writes:-Mrs. W. Stafford sars "Miss Lippincott's Seeds will grow, for I've tried and proved them." So on her recommendation I will try them.

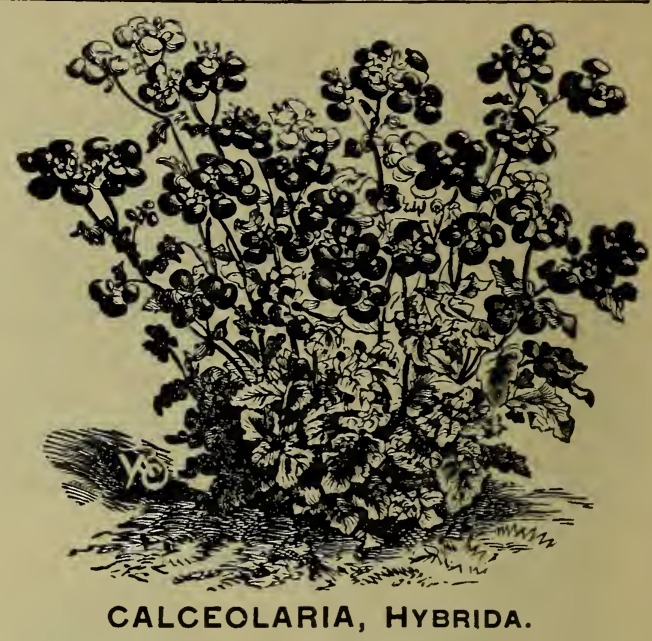

A favorite and universally admired plant, remarkable for their large beautifully spotted blossoms, which are very showy, and from which an almost countless number of hybrids have been raised. They are perennial, are grown in pots in the conservatory, green-houses and gardens. Mixed Colors, Pkt. 12 cts.

WITH PERFECT CONFIDENCE.

Mrs. M. E. Wood, $859 \mathrm{E}, 169$ th $S t$, New York city, writes:-The Flower Seeds I'sent for a slort time ago proved entirely satisfactory, and it is with perfect confidence $I$ send for the following selection. IVishing you great success in your business.

\section{BLOOMED SO LONG.}

Mrs. W. C. Peckins, Highland, N. Y., writes :The Seeds you sent me last year proved very satisfactory and we all enjoyed the flowers, particulariy the Phlox Drummondii-the colors were so rich and they bloomed so long. 


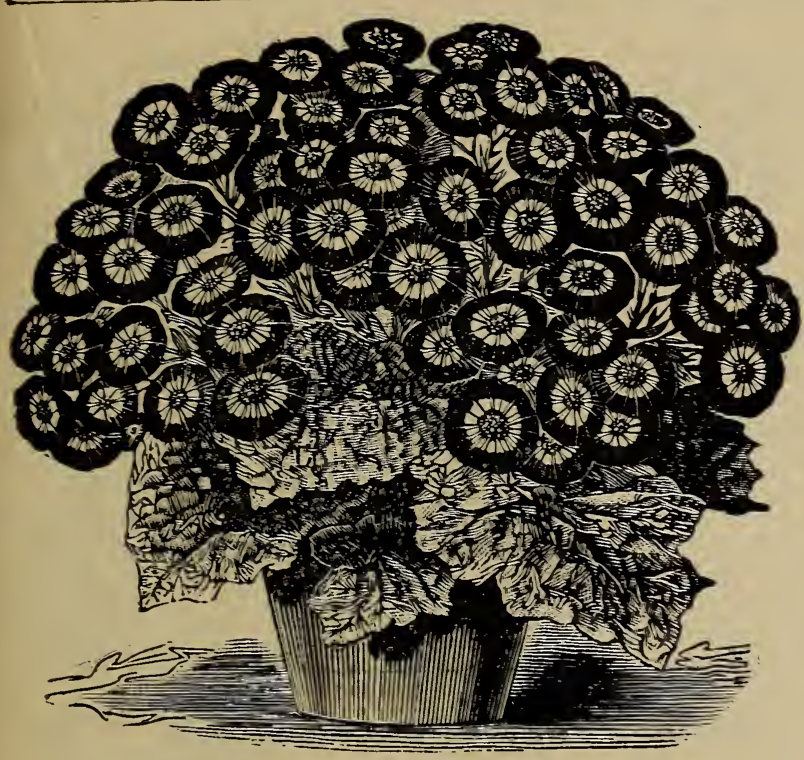

\section{CINERARIA, HYBRIDA.}

One of the most popular of all green house plants and what a splendid display they make when well grown. I know of no plant so EASILY GROWN as the Cineraria. The secret of growing well is to grow fast; never allowing them to receive a check, either from being pot bound, dryness of root, or attack of insects; the cooler they are kept the better. In colors they range from crimson, magenta, violet, purple and variegated. Large flowering mixed. Pkt. 12c.

\section{SIX DIFFERENT SEEDSMEN.}

G. M. Barnaby, Gig Harbor, Wash., writes: The seeds $I$ purchased of you last year proved, "out of six different seedsmen" that I had seeds from, to be the finest and most beautiful flowers of them all.

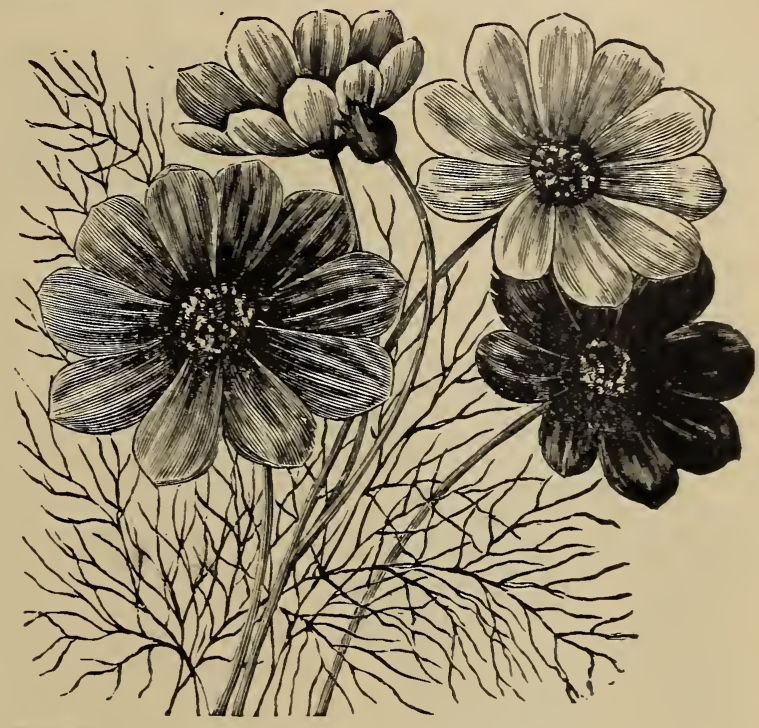

COSMOS, HYBRIDUS.

A plant of strong growth, having elegant foliage, and for fall blooming has no superior. Seed sown in April or May and transplanted to open ground will produce plants five or six feet high by September, and from then till November will be covered with hundreds of blossoms three inches across, resembling single Dahlias. Planted in pots and brought inside to flower like Chrysanthemums, they are grand. They are of various shades, from pure white to purplish crimson. Both foliage and flowers are unsurpassed for bouquets and vases. All colors mixed, Pkt. 6c. cosmos-pure white, Pkt. 6 cts.

A FREE PREMIUM of elegant roses on Seeds in packets to the amount of $50 \mathrm{cts}$. and upwards. (See page 48 ). Something worth having. 


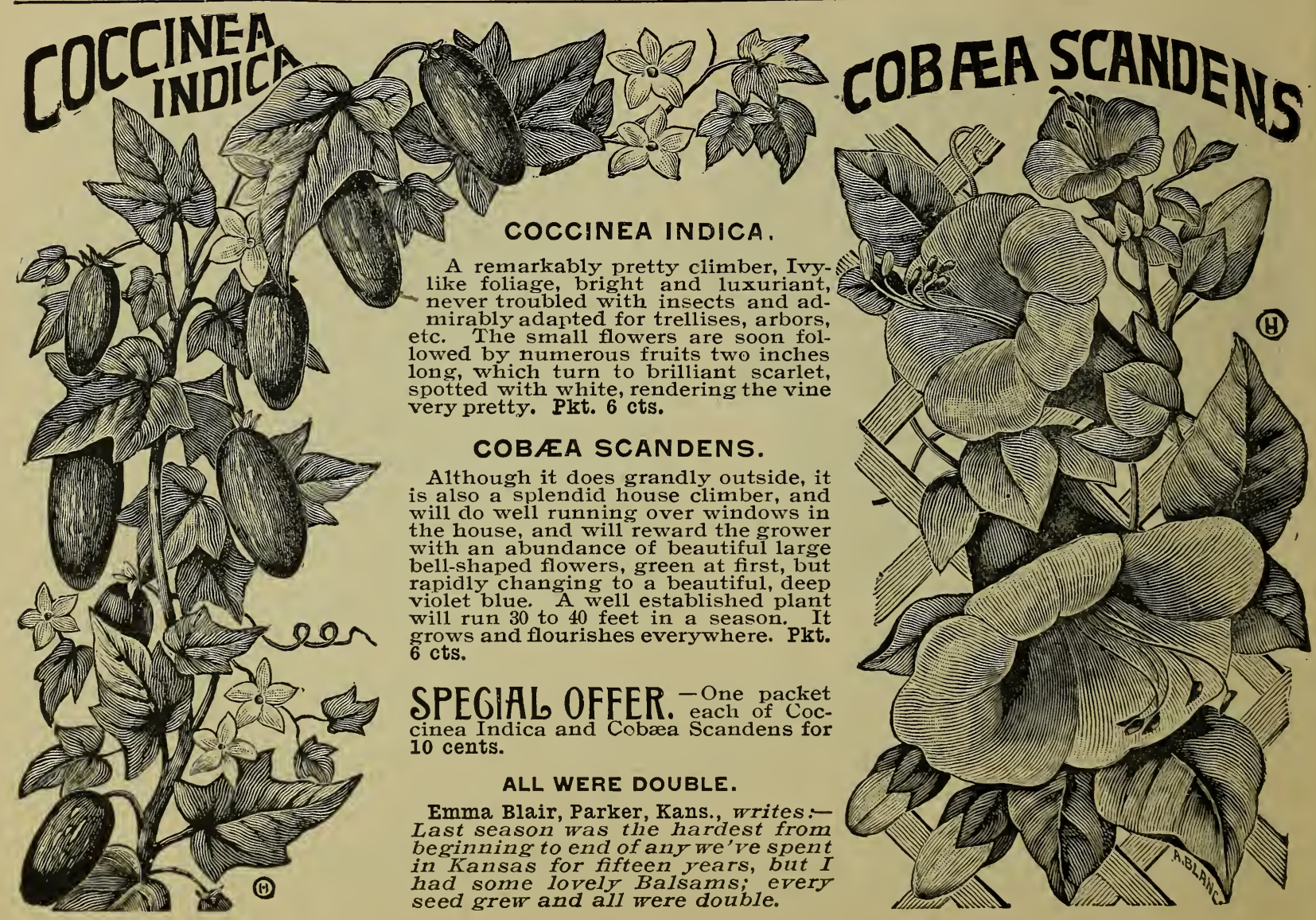




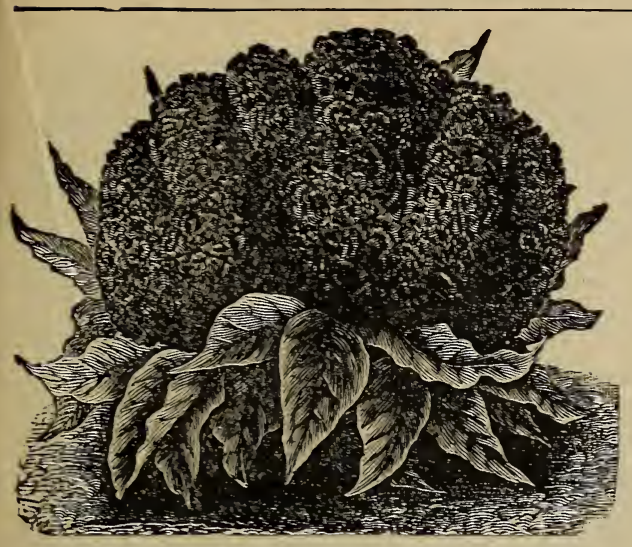

COCKSCOMB, QUEEN OF DWARFS.

This is the best dwarf-growing Cockscomb,the plants only grow about eight inches hish, are ñmly set in the crown with wellbalanced, large heads ten to twelve inches across. They grow very uniform and present an unusually solid effect in color, which is a rich ruby-red of extreme brilliancy. Pkt. 6 cts.

cockscomB-mixed, Pkt. $3 \mathrm{cts}$.

\section{BLOOMED ALL WINTER.}

S. A. Fitz, Woodland, Cal., writes:-Some pansies and pinks has bloomed all winter. grown from seeds you sent me last spring. Hope you will succeed in your good work, make a fortune, and come to Californiathe "latch string" is always outside here.

ONE AMONG MANY.

Mrs. Lee Young, Stephenville, Tex., writes I am glad to see "a woman" launching in the seed business. I think that the cultivation of flowers is certainly a siuit able occupation for our sex; and I am only one among many who wish you great success.

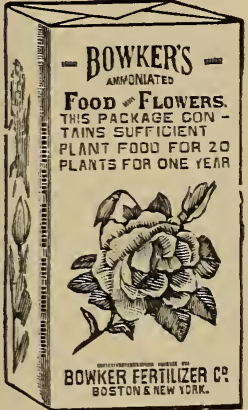

\section{BOWKER'S} PLANT FOOD.

This is a most useful Fertilizer ror all kinds of plants raised in pots. It produces rapid and vigorous growth and an abundance of flowers. It is odorless and takes the place of liquid manure. Drives all insects out of the soil. Price per package, containing sufficient plant food for 20 plants for 3 months, 8 cents post paid. $\mathrm{Each}$ package contains full directions.

ROSES Given Away. Two magnificent 48 for descriptions.

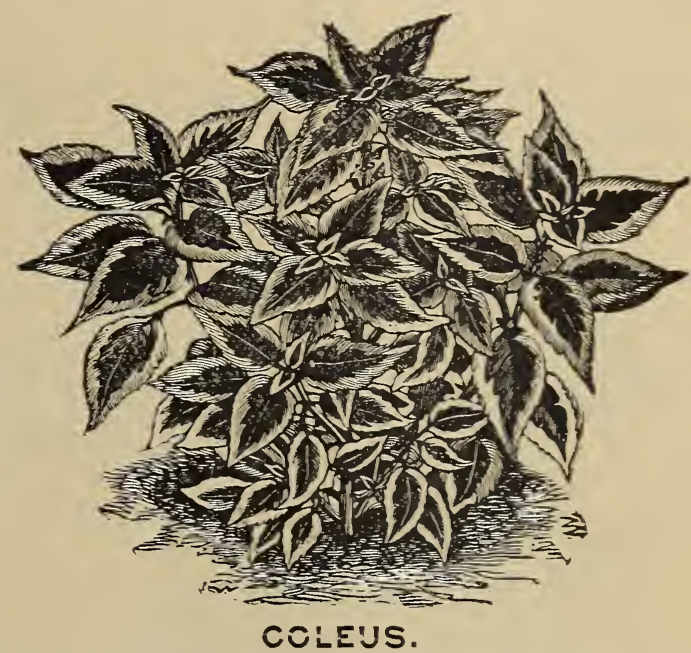

One of the best known and most universally ad mired ornamental foliage plants, in an endless variety of colors and shadings, indispensible for ribbon and carpet bedding, or as single specimens. Coleus seed germinates easily and success is as sure as with an ordinary annual. Pkt. 8 cts.

\section{CYPRESS VINE.}

A most beautiful vine with delicate fern-like folige and beautiful star-shaped rose, scarlet and white flowers. Seed very slow to start growth. All colors mixed, Pkt. 3 cts.

\section{HURRAH! FOR A WOMAN!}

Mrs. L. E. Akins, Granville, Ohio, writes:-The seeds you sent me last year were all good, my boxes were full of nice sturdy plants in a very short time after sorving. I always feel like saying "Hurrah!!" for a woman who inas enough pluck and ability to carry out a new enterprise. 


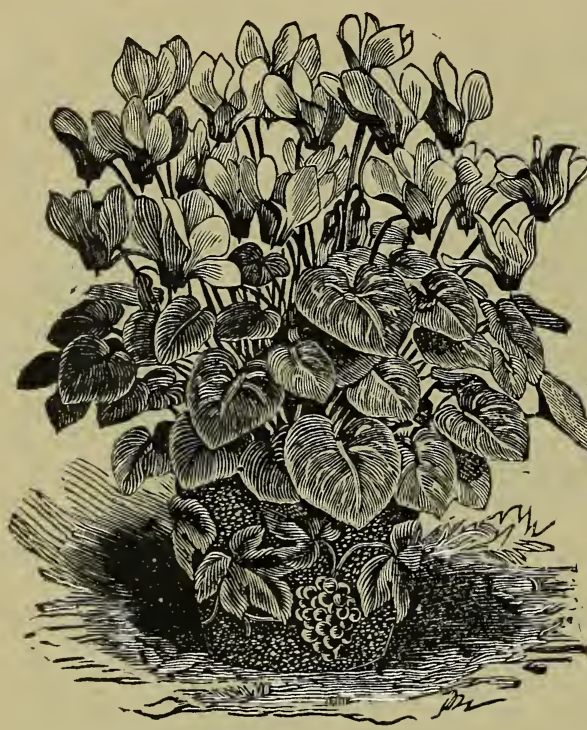

CYCLAMEN, PERSICUM.

Well known bulbous-rooted plants, universal favorites as pot plants for Winter and Spring blooming, producing handsome red and white flowers with beautiful variegated foliage, in different shades of green. The seed should be sown in the spring, and by autumn will produce a bulb which will blossom the following spring. Mixed, Pkt. 8 cts.

CYCLAMEN, Giganteum, Mixed, Pkt. 12c.

$$
\text { AS REPRESENTED. }
$$

Jessle E. Hungate, Pullman, Washington, writes:- Your low prices and the promptness with which you return orders, is indeed pleasing. They are
truly "as represented."
A BEAUTIFUL SIGHT. Mrs. B. F. Downing, Chardon, 0., writes:I sent to you last March for Hollyhock, Poppy and Dahlia seeds, which I soon received and planted in shallow window boxes. The plants were very thrifty and I planted them out in the ground the middle of May. The middle of Juiy the Dahlias were loaded with lovely blossoms, a beautiful sight to behold-people generally would not believe they came from seed. Hope success may attend you.

A POT OF DIRT.

Mrs. W. Hope, Manhattan, Kans. writes I am getting old, but my love for flowers, I be 1 i e ve, increases; there is nothing that gives me more pleasure than a flowereven of the plainest kind; and I think every" one that can get "a pot of dirt" ought to grow one, if no more. Hoping that you may go onward and upward in your undertaking, for what man has done-"woman" can. BEAUTIFUL FLOWERS.

Miss Ida Marshall, Hemlock, 0., writes:I raised a beautiful lot of flowers from the seed $I$ bought of you last season.

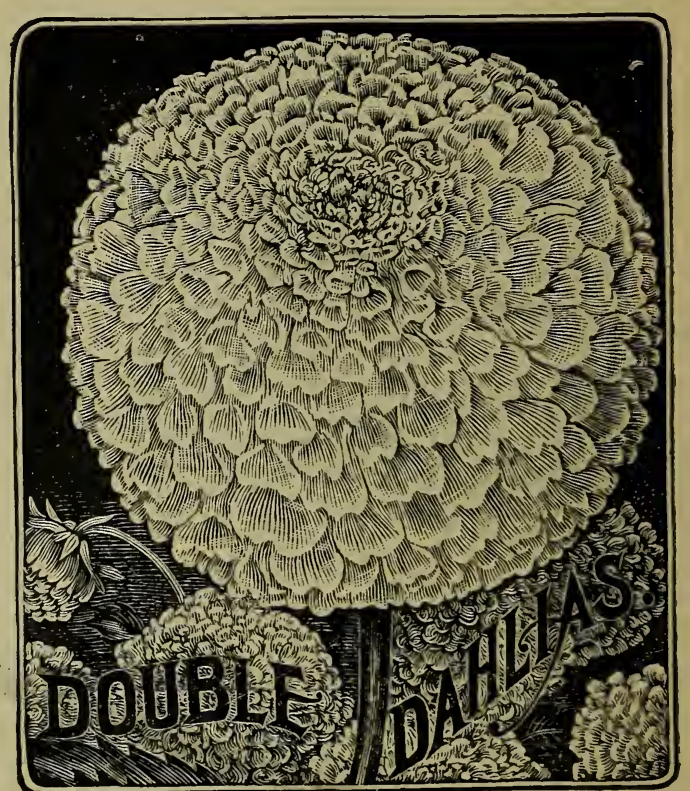

DAHLIA, DOUBLE.

Every one knows and admires the Double Dahlia, but comparatively few are aware that it can be grown so easily from seed and flowers so beautifully the first season, that the purchase of bulbs is a needless expense. Choice Mlixed Seed, Pkt. 4 cts.

\section{DAHLIA, NEW STRIPED SINGLE.}

The extra large single flowers, quite four inches in diameter, comprise a wonderful variety of colors, beautifully striped, flaked, mottled and dotted in a grotesque and charming manner. Pkt. 6 cts. 


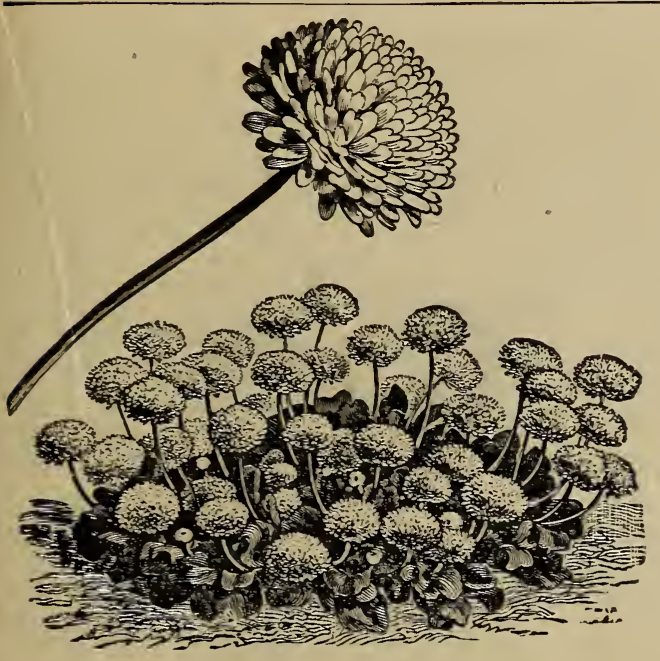

DOUBLE DAISY, (BELLIS PERENNIS.)

Daisies are easily grown from spring sown seed and come into flower in a very short time. The flowers are white, pink, red and variegated. Not all will come double from seed. Finest mixed, Pkt. 6 cts.

\section{NEW SNOWBALL UAISY.}

A beautiful white flowered variety having very long stems with large double flowers; about 80 per cent. of which are extremely double. Pkt. $6 \mathrm{c}$.

\section{SOME APPEARANCE OF HONESTY.}

Mrs. J. L. Wykoff, Pinney's Corners, Pa., writes: - Most catalogues are such high-colored,highpriced, exaggerated affairs, it seemed good to see one with some appearance of honesty. Must thank you for the Seeds sent last spring; they all grew.

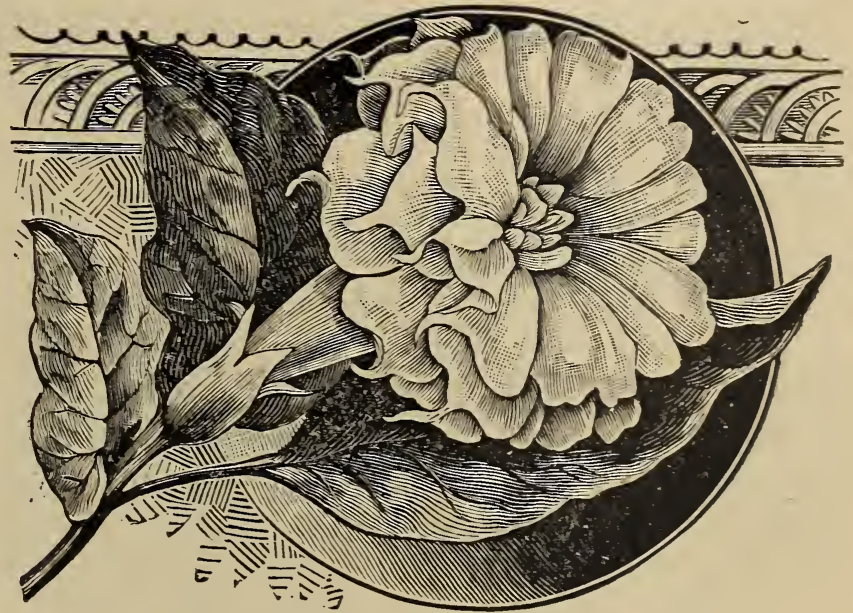

DATURA, OR TRUMPET FLOWER.

Large branching plants, producing handsome double and single trumpet shaped blossoms, white, blue, yellow and lilac, of exquisite fragrance. The blossoms open during the night, remaining oper one day and then perish. They bloom freely from seed sown in the open ground the first season, and the roots can be taken up and kept over winter the same as Dahlias. Pkt. 3 cts.

\section{DELPHINIUM, OR LARKSPUR.}

Well known annuals of great beauty and remarkable for the richness of their colors, and for large gardens is invaluable. All the brightest and best colors mixed. Pkt. 3 cts.

DELPHINIUM, FORMOSUM, a hardy perennialvariety, flowers tright blue with a white center. Pkt. 3 cts.

\section{YESI IT'S MY PICTURE.}

Mrs, John MacBride, Middletown, N. Y., writes:-Last rear I planted some of your seeds and they proved very satisfactory, having many nice plants and blooms. Is the picture on your catalogue, one of yourself? 


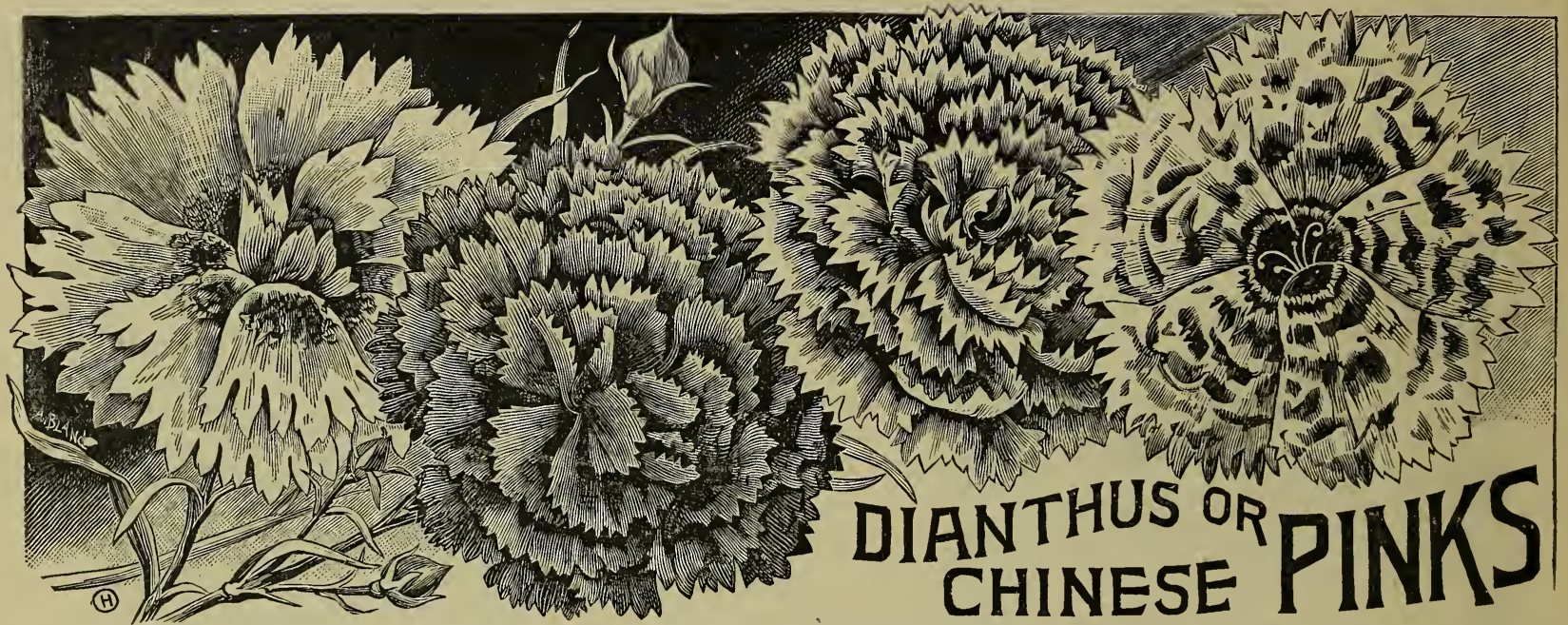

One of the most useful and desirable plants, and for beauty and variety of colors and markings cannot be surpassed, ranging from pure white to the most delicate pink and glowing deep crimson. A bed of these in the flower garden will make a grand display at small cost. The mixture I offer this season is much superior to any previously offered and includes, besides the standard sorts, all the new and brightest colors in spotted, striped and handsomely fringed varieties of late introduction. I guarantee it will give satisfaction with any other strain offered. Pkt. $6 \mathrm{cts}$.

DIANTHUS (Chinese Pinks), Good Mixed, Pkt. 3 cts.

\section{DIANTHUS, DWARF FIREBALL.}

The most brilliant annual pink in cultivation, the plants are constantly covered with blood-red, perfectly double laciniated flowers until checked by severe frost. Pkt. 6 cts.

SENDS AGAIN, - Mrs. M. E. James, Ft. Payne, Ala., writes:-I was so much pleased with the Flower Seeds that I got from you, last spring, that $I$ send again. I think your enterprise a very delightful one and wish you every success.

THE ADMIRATION OF ALL--Miss M. V. Baughman, 1638 Curtis St., Denver, Colo., writes:-I was highly pleased with the flowers grown from the Seeds purchased of you last year. The Asters were the admiration of all who saw them.

ABOUT HALF PRICE.-Mrs. Sallie T. Gill, Roxie, Miss, writes:-The Seeds $I$ purchased of you last year gave perfect satisfaction, so $I$ send a larger order this season, still it is not more than half I would have to pay elsewhere. 


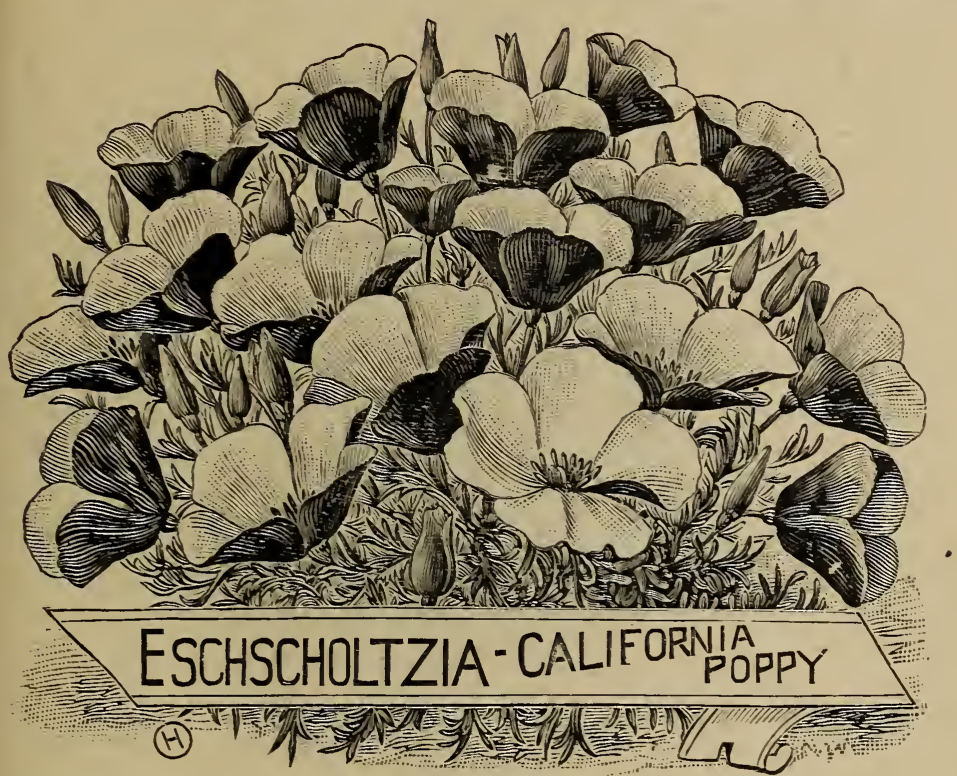

Hardy annual, growing about one foot high, bearing a profusion of rich yellow flowers about two inches in diameter, making a blaze of color in the sunshine. Pkt. 3 cts.

\section{EUPHORBIA HETEROPHYLLA. (MEXICAN FIRE PLANT.)}

The plants grow two to three feet high with a branching, bush-like form, with smooth, glossy, fiddle-shaped leaves, which are at first entirely green, but about midsummer, at the end of each branch appear greenish-white flowers, enveloped in beautiful orange, scarlet bracts, and the surrounding leaves are either blotched scarvivid carmine or are carmine with green tips. It is an annual plant, but should be started early so it will have sufficient time to develop its brilliant colors. Pkt. 6 cts.

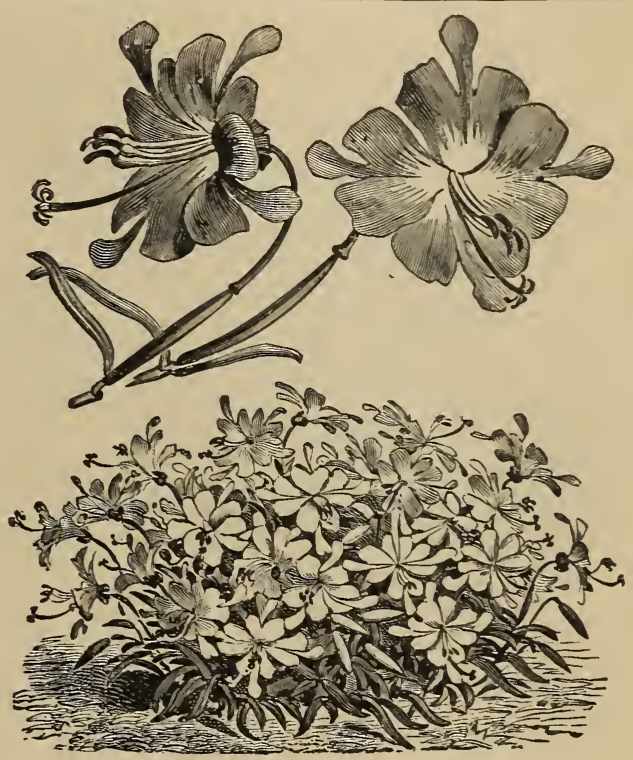

\section{EUCHARIDIUM, BREWERI.}

A pretty and showy dwarf summer flowering annual; flowers of a purplish rose shading to white in the center. It flowers very profusely and is of easy culture. A distinct and truly elegant plant. Pkt. 8 cts.

WELL SATISFIED.

Hattie M. Wagner, Faulkner, Iowa, writes:Last Jear I bought your Bargain Collection and was pery well satisfied with it.

\section{VERY MUCH PLEASED.}

Mrs. F. A. Ruggles, Three Rivers, Mass., writes : $I$ was very mich pleased with the resilt of your seeds last year. 


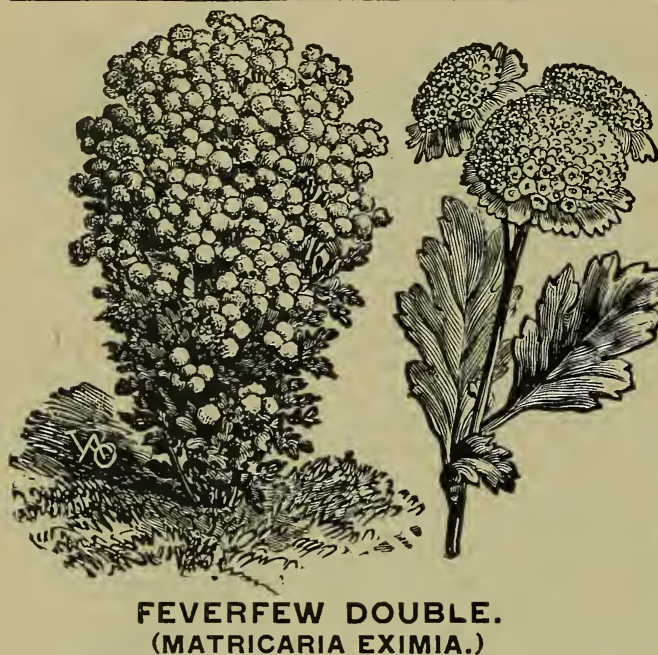

Handsome large double white flowers; a fine bedding plant or for pot culture; as desirable as a good Aster, very free flowering, blooms until frost, height 18 inches. Pkt. 4c.

MOST PROMPT REPLY.

Mrs. Geo. Hinchliff, 2047 Park Ave., Evanston, Iil., writes:-Last year I answered six Seed advertisements and you were the most prompt in reply.

\section{TRANSPLANTING TROWEL.}

A Solid Stee1

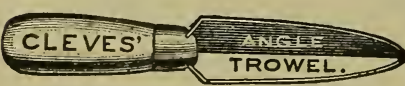

Trowel of new form for transplanting, lifting or setting plants or bulbs, or for the lawn as a Plantain or Dandelion digger, in fact, it is an "all around" Handy Digger for the Flower Garden. Price 20 cts, postpaid.

(Not allowed to be selected as premium,)
EXTRA GOOD. Jessie A. Rose, Morning Side, Sioux City, Iowa, Writes:-The Pansies we planted came up in about a week. So think Your s e eds must good.

\section{LOVELY} BOUQUET.

Mrs. J. T. Mardock, Aledo, I11., writes:-The seeds you sent melast season grew fine 1 y, and were the means of self and friends enjoying many a lovely bouquet.

IN BLOOM NOW. Mrs. Abbie Hutson, San Gabriel, Texas, Writes:-I Was very much pleased with the seeds I bought of you last spring, I have great clusters of blotched Petunias in bloom now, ( Jan. in bloom now, (Jan. window.

\section{HAVE YOU}

\section{Ever tried "Thun-} bergia"for Hanging Baskets? If not, do so. (See page 42.)

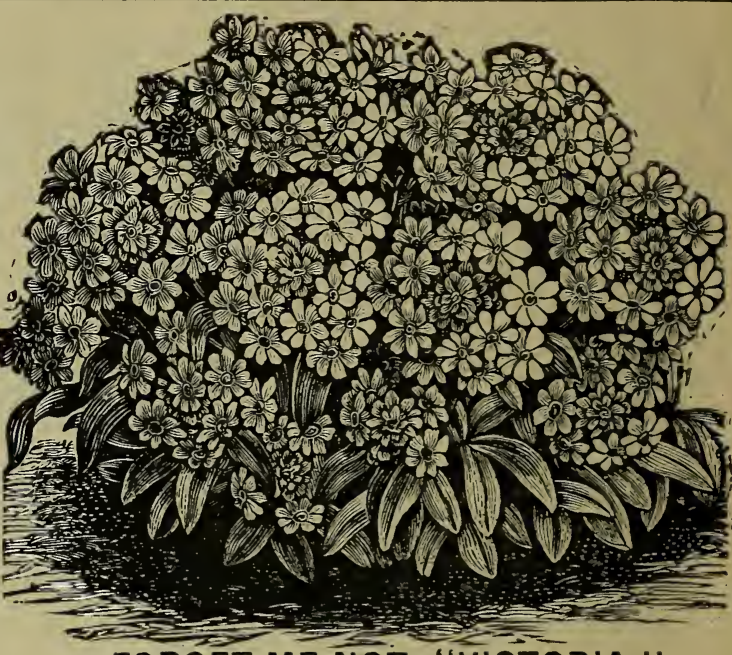

FORGET-ME-NOT, "VICTORIA.", (MYOSOTIS.)

Of stout and bushy habit of growth, bearing um bels of large, bright, azure-blue flowers, with central double blooms. The plant attains a height of 5 to 7 inches, with a diameter of 8 to 10 inches, and when fully grown is quite globular in shape, and perfectly covered with flowers. This beautiful Forget-menot is the best for carpet bedding, edgings and masses, and for growing in pots. Pkt. $4 \mathrm{cts}$.

PROFUSION OF BLOSSOMS.

Mrs. C. Elmer Weeks, Patchogue, Long Island, N. Y. writes:-The Verbenas that I' got of you have been the admiration of all my friends this win ter, for their profusion of bloom.

\section{LOKING BEAUTIFULLY.}

Mrs. W. H. Phillips, Nicholasville, Ky., writes; $-I$ ordered seeds from you some time ago and they are up and looking beautiful, especially my Sweet Peas. 


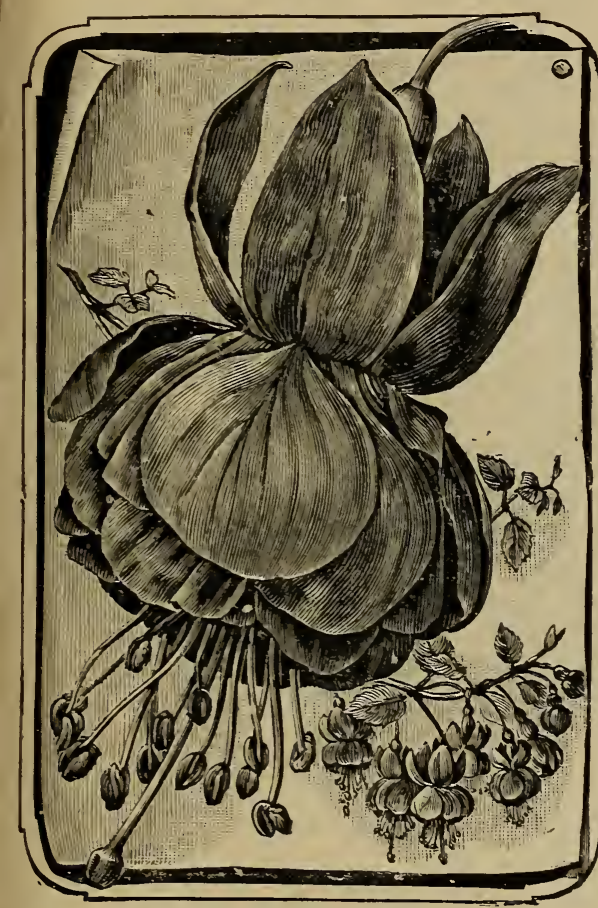

FUCHSIA. DOUBLE AND SINGLE MIXED.

Fuchsias are as easily grown from seed as cuttings, and from seed many new varieties are obtained. They will flower freely the first year in the open ground, while the plants can be taken in the house in the winter where they will flower still more freely. Pkt. 12 cts.
FIRST-CLASS SEEDS.

Miss Minda M. Brown, Dufseeds I ordered from you last year came promptly and were first-class seeds. May you have success.

\section{SURPRISED AT THE} QUANTITY.

Miss Leona Paradine, Coldwater, Mich., writes:-My sister sent to you for some seeds this spring and I was surprised at the quantity of seeds for so little money.

\section{A FELLOW FEELING.}

Mrs. M. L. Fleshmen, Derby, Kans., writes:-You are a woman and love flowers; and a "fellow feeling makes us wondrous kind." With best wishes.

\section{DON'T SEE HOW.}

Mrs. Fred O. Carter, Thorndike, Mass., writes:-I was so much pleased with your seeds lastyear, they came up so well. I do not see how you can sell flower seeds so cheap and give your customers presents besides, $I$ wish jou success.

Q11 Old Cosmos is one II of the few flowers that does not ea sily succomb to frost, and in favored localities remains in bloom until the last of November, being fully as hardy as the Chrys. anthemum. (See page 11.)

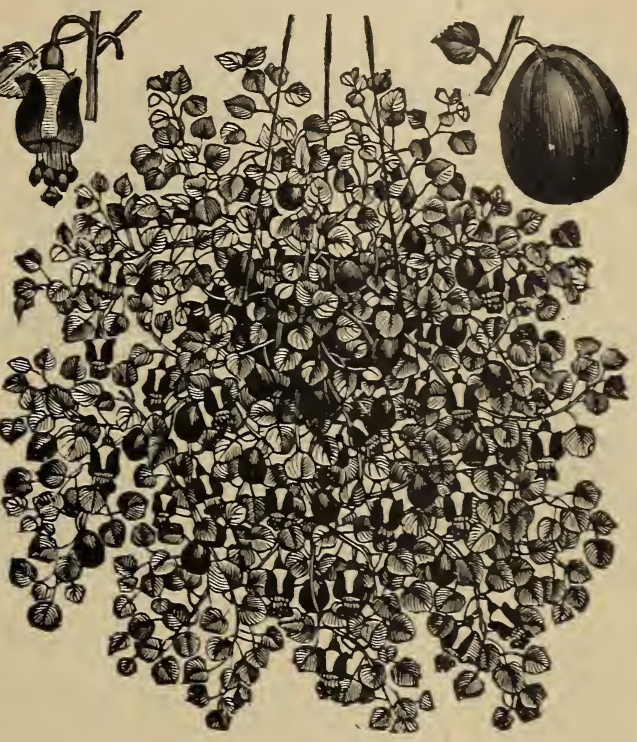

FUCHSIA, PROCUMBENS.

(THE TRAILING FUCHSIA.)

This species makes one of the prettiest trailing plants imaginable. IVhile the flowers are small the vines are of graceful habit, with pretty leaves and bright red berries, which make a fine effect hanging over the sides of a pot, basket or vase. The berries are about the size and shape of robbins' eggs, of deep crimson red, ornamenting the plant for as long as six months at a time. Pkt. $8 \mathrm{cts}$.

R Elf $R$ Take adrantage of my 1E En Liberal Offer (See page 48) and secure one or both of the grand Roses offered FREE. 


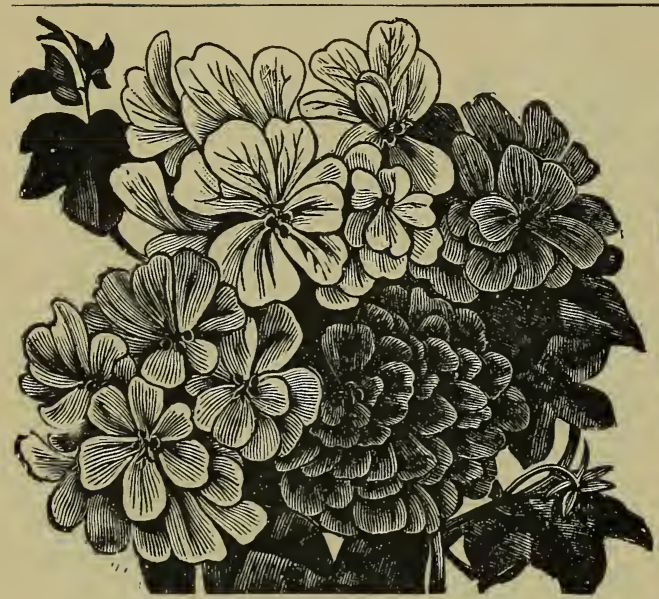

GERANIUM.

The most popular plant grown either for pot culture in winter, or for bedding out in summer. No flowering plants are more grown and certainly none are more suitable for large beds, where a mass of bloom is desired or for single specimens in pots for the house. But few are aware that they can be grown easily from seed and flower the first season, if sown early, and will frequently reward the cultivator with charming new varieties, in fact, propogation by seed is the only sure way to obtain new varieties. The seed I offer this season has been saved from 25 of the finest varieties grown, including Mad. Thebault, Mad. Garfield, Gen. Grant, Capt. Ainsworth, Little Gem, Cloth of Gold, Happy Thought, Snow on Mountain, Adonis and Beaconsfield; also included in this mixture are 7 varieties of Pelargoniums, or Lady Washington; and two Ivy-leaved varieties. There can be no finer mixed Geranium and it cannot fail to bring forth some splendid new varieties. Pkt. $16 \mathrm{cts}$. GERANIUM-good mixed. Pkt. $8 \mathrm{cts}$.

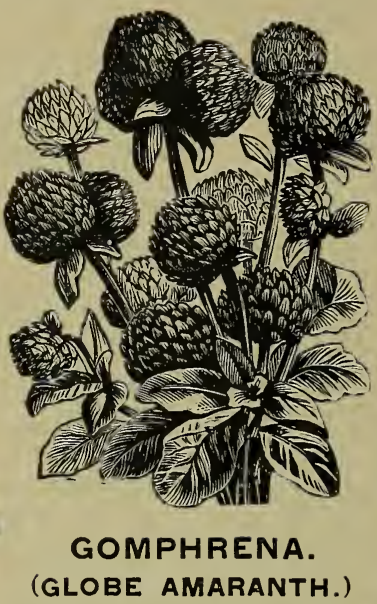

A desirable everlasting valued for its handsome globular flower heads, which, if cut when well matured will retain their beauty for years. Pkt. 3 cts.

\section{GILIA.}

A hardy annual, very delicate in leaf and flower, grows in almost any situation in Pkt. 3 cts.

\section{JUST TOO CUTE.}

Miss Minnie Cline, Sabina, o., writes:- IVe never had flowers to do as well as those grown from your seed last season, and the way they were put up in packets, was just too cute.

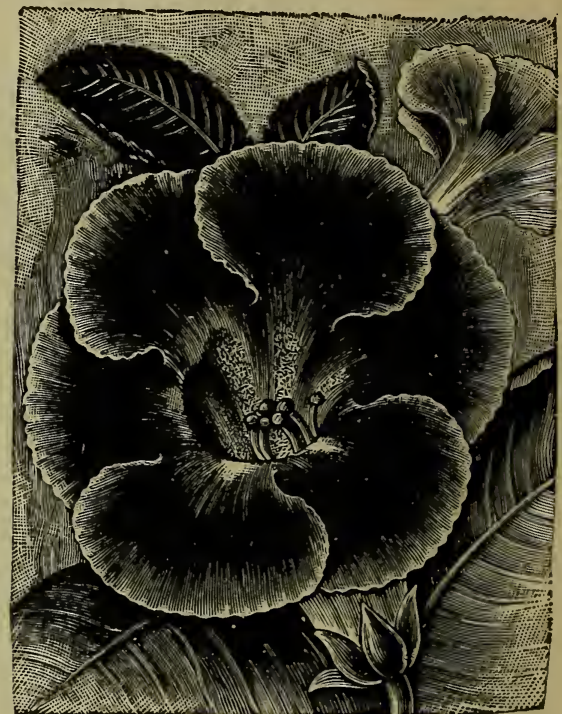

GLOXINIA. a lovely pot plant as easily grown and cared for as many of the common flowers. The handsome bell-shaped flowers embrace a great variety of the richest and most beautiful colors, ranging from pure white to dark, blood-red. pink, blush, lavender, indigo-blue, marbled and spotted. They will bloom in four to five months from time seed is sown. Pkt. $12 \mathrm{cts}$.

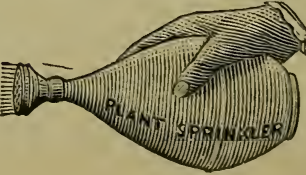

Rubber Sprinkler.

For sprinklingcut flowers, seedlings, plants, clothes, etc. Price 50c., postpaid. (Not allowed to be selected as premium.) 


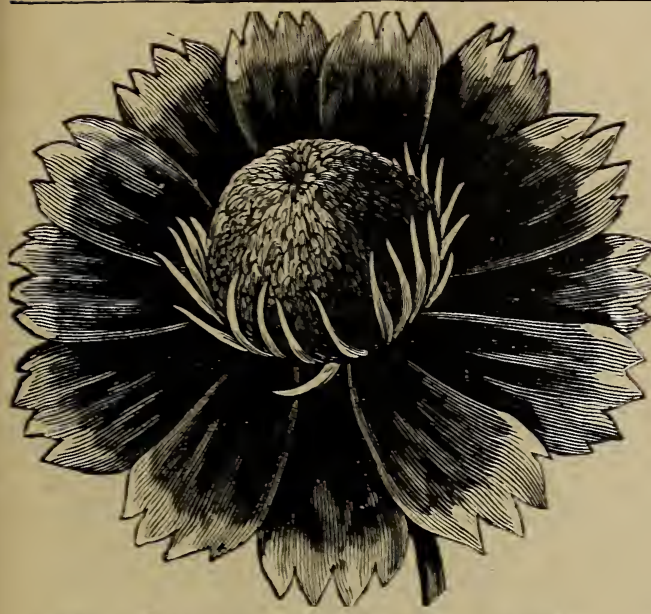

GAILLARDIAS, (BLANKET FLOWER.)

Valuable annuals greatly admired for their fine forms and rich blending of colors, the gay colored flowers being abundantly produced from July until frost. While they thrire anywhere, single and double mixed. Pkt. 3c.

\section{GAILLARDIAS, HARDY PERENNIAL.}

These are unrivaled for brilliancy and rich blending of color and for profusion of bloom which is continued from early summer until frost. They are, without question, one of our choicest Hardy Perennials and are exceed. ingly effective when grown in masses on rich ground in a sunny. situation. If seed is sown early in pots in the house, or in a hotbed, the plants will come in to flower in June, as corsage flowers, or for vases they are unrivaled and last a long time after being cut. Pkt. 6 cts.

\section{CAME PROMPTLY.}

Mrs. W. F. Wilson, Columbia, Tenn., writes: The seeds I ordered of you, came promptly, and nearly all of them are sown and up.

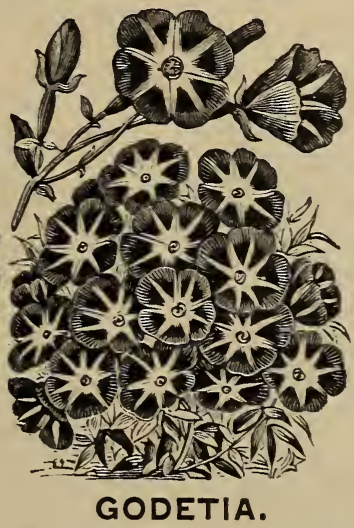

Beautiful hardy annuals remarkable for the delicacy of their very fine large blossoms; fl owe rs deep rose pink, rosy carmine, snow - white, with bright carmine rose spots, carmine crimson, lilac iny white. Pkt. 3 cts.

\section{GOURDS, (ORNAMENTAL.)}

Tender annual climbers with curiously shaped $f r u$ it in various colors, many of which are peculiarly marked. The foliage is quite ornamental, and many of the fruits being hard-shelled, can be kept for years. Seed should be started in pots in the house and planted out as soon as danger from frost is past. Fine mixed. Pkt. 6 cts

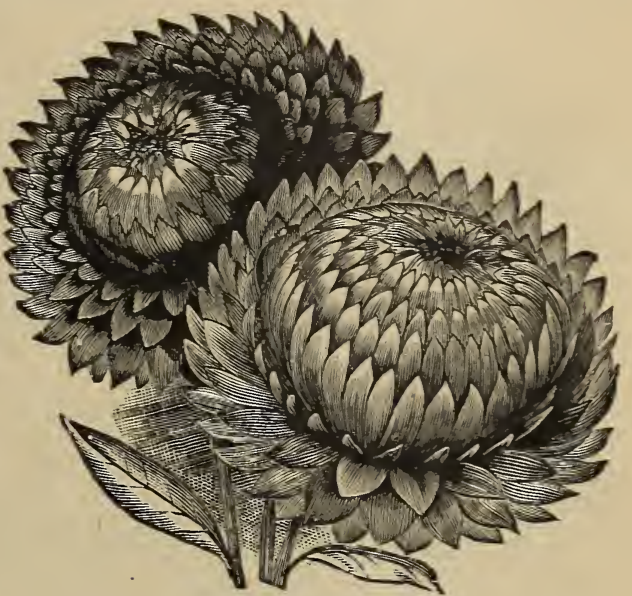

HELICHRYSUM.

A very popular everlasting, large full double flowers of rarious colors, from bright yellow to scarlet, shaded and tipped. Handsome bouquets may be formed of them for winter, if blossoms are gathered when on the point of expanding. Pkt. $3 \mathrm{cts}$.

\section{HUMULUS, JAPONICUS.}

(IAPANESE HOP.)

One of the most rapid climbers grown, seed can be sown in the open ground in spring and it will attain enormous dimensions very quickly. The foliage is luxuriant and it is one of the best plants for covering verandas and trellises. Heat, drought and insects do not trouble it. Pkt. 6 cts.

FEV FI DYERS Equal the PeF C LUVRS tunia for brilliant display, being of the easiest culture and rery profuse bloomers from June until frost. Try my strain of Grandiflora. (See page 33 .) 


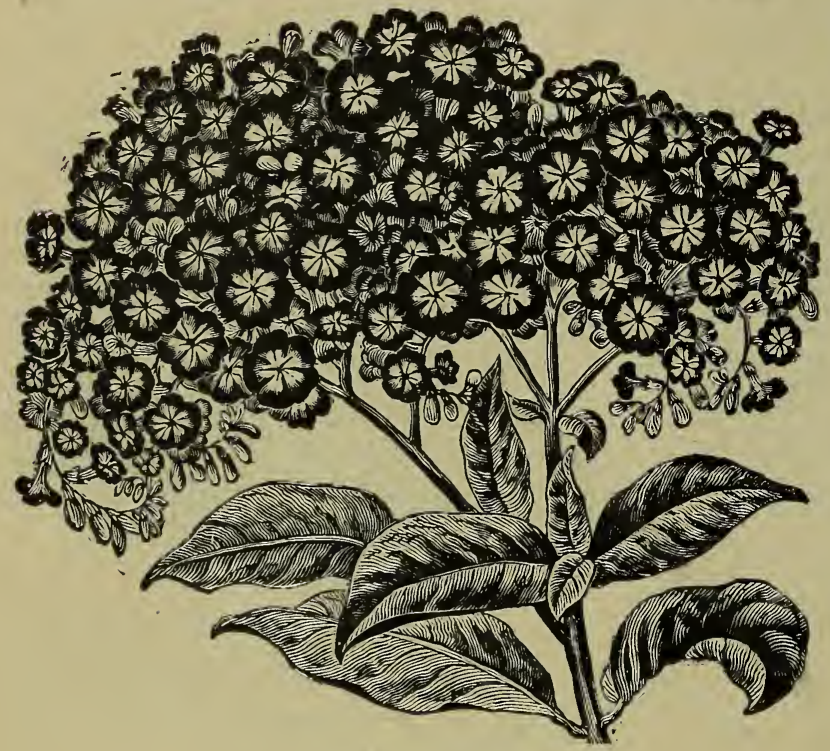

HELIOTROPE.

The Heliotrope is a universal favorite on account of its delightful fragrance and duration of bloom, flowering equally well as bedding plants in summer, or as pot plants in the house during winter. Seed sown in the spring makes fine plants for bedding out and are as easily grown as Verbenas. Pkt. 6 cts.

\section{JUST AS RECOMMEDED.}

Mrs. L. J. Officer, Lebanon, Tenn., writes:-The seeds $I$ purchased of youlast year proved to be very nice and jus: as recommended.

A TASE For flowers and plants is a bond of symin every land and condition. Their language is universal.

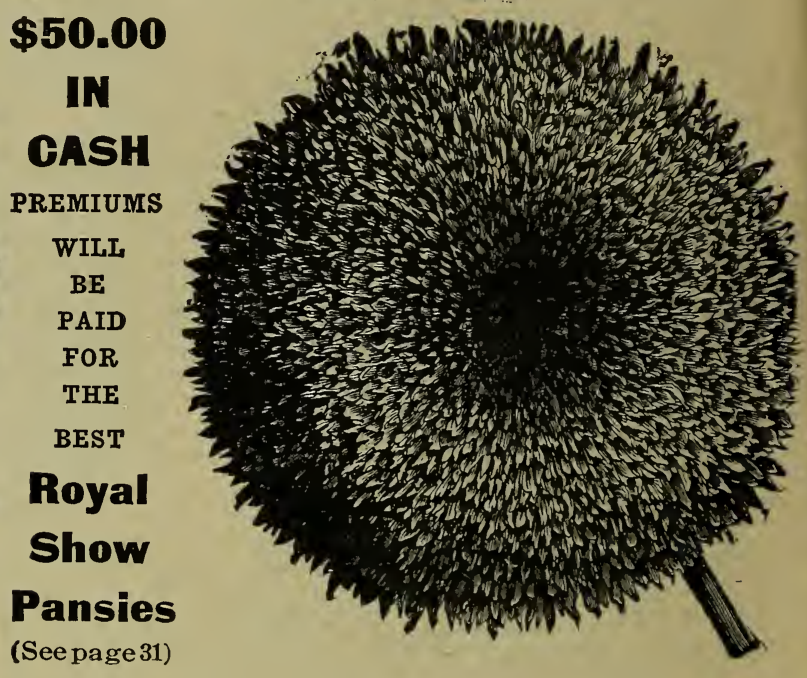

HELIANTHUS, (SUNFLOWER.) GLOBOSUS FISTULOSUS.

The best and most effective of all annual Sunflowers, flowers immense, from 12 to 15 inches in diameter, globular and extremely double. For a background to a lawn or a screne to hide unsightly places it is especially adapted. Of easy culture as well as showy. Pkt. 3 cts.

\section{THE LOVELIEST FLOWERS.}

Mrs. R. A. Patterson, Spring Creek, Pa., writes -The seeds which $I$ obtained of youl last year produced some of the loveliest flowers I ever saw.

\section{A LITTLE GEM.}

Miss Daisy Richardson, Tracy, Minn., n rites $-I$ was very much pleased with the seeds purchased from you last year and think your catalogue a little gem. 


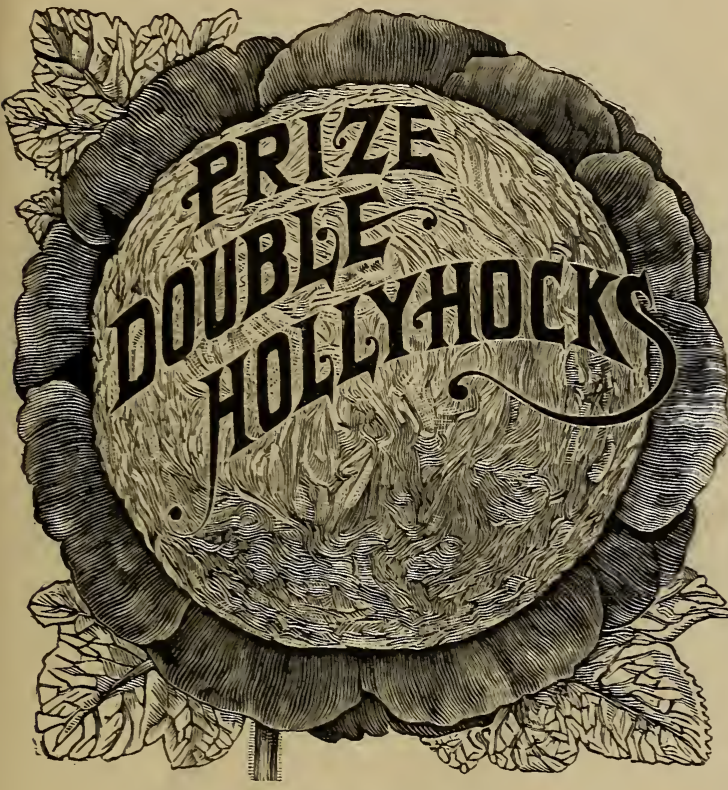

HOLLYHOCK, PRIZE DOUBLE.

The perfect doubleness of the magnificent, large flower will please the most critical. All the best colors, from deep yellow, red rose, light buff, carmine scarlet, flesh color, creamy white tinted with rose, purple, yellow on dark ground, crimson flaked with salmon, cherry red, cream on violet ground, lilac on brown ground, dark crimson to pure white, also black. If sown early in March or April the plants will bloom the first year. All colors mixed. pkt. 6 cts.

\section{WELL PLEASED.}

Miss Mary Purmort, Memphis, Mo., writes:- IVe bought seeds of youl last year and was well pleased with them. Wishing you success.
ICE PLANT. (MESEMBRYANTHE MUM.)

A handsome and curious plant for hanging baskets, rock work and vases. The leaves and stems appear as though covered with ice crystals and look like rock candy. The whole plant is peculiarly brilliant in the sunshine. Pkt. 3 cts.

\section{IMPATIENS}

SULTANI.

This most distinct and beautiful plant is a 1 most a perpetual bloomer. The flowers are of a brilliant rosy, scarlet color, and are produced so freely that a well grown specimen appears to be a ball of flowers, and continues in full beauty during sereral successive months. It is far more decorative than the best of double Bal sams, and is more easly grown. Pkt. 8c.

\section{MORE THAN PLEASED.}

Mrs. Edwin Phalen, Acton Centre, Mass. writes:- I was more than pleased with the flowers I got from the seed you sent me last jear, all being per fect in form and color.

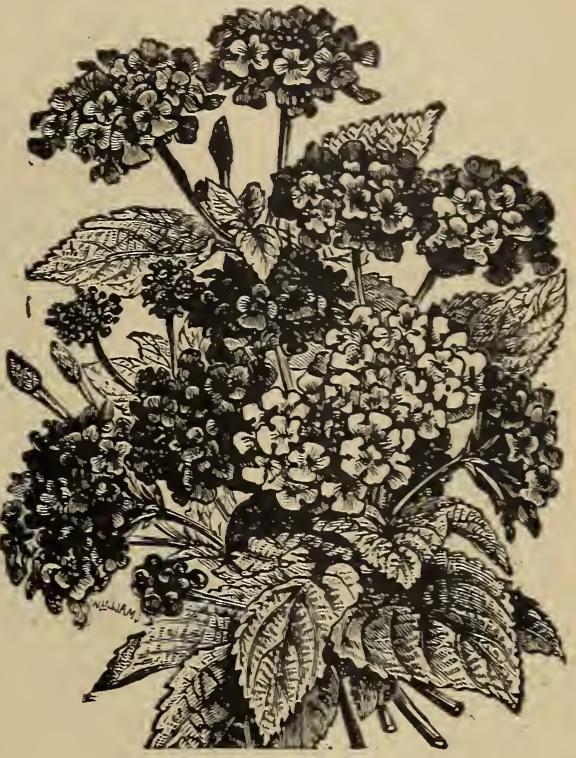

LANTANA.

Well-known shrubby plants, with clusters of verbena-like flowers, and producing their pink, yellow, orange and white heads in great abundance. They have an agreeable aromatic perfume. Finest mixed. Pkt. 4 cts.

\section{LATHYRUS. (PERENNIAL PEAS.)}

They do not hare the delicious fragrance of the Sweet Peas, but they are equally as beautiful. They are perfectly hardy and live year after year, bearing magnificent clusters of flowers and bloom early in the spring. Pkt. 3 cts. 


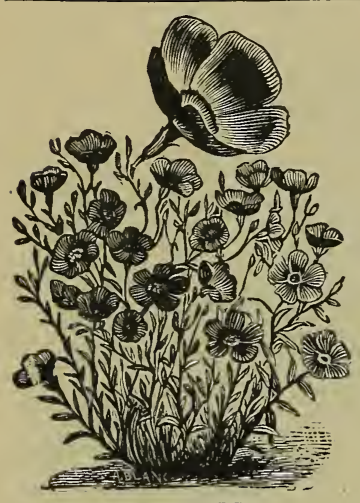

LINUM,

(CRIMSON FLAX.)

Excellent for clumps or edgings and one of the best and most showy hardy annuals for bedding. May be raised in any quantity from seeds sown in March or April, where the plants are intended fastidious regarding soil, doin weil in any ordinary garden. Pkt. 3 cts.

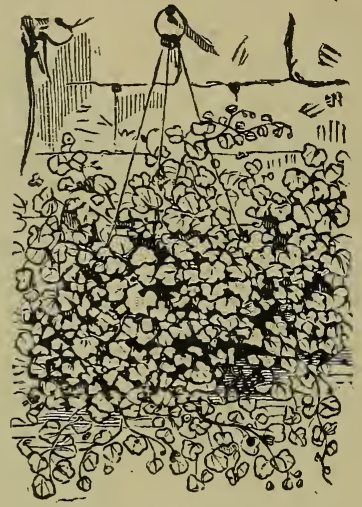

LINARIA,

(KENILWORTH IVY.)

A very pretty and wellknown hardy perennial trailing plant, for covering rock work, and very useful for hanging baskets. The flowers are small, but pretty, and for a drooping plant nothing can be better as it is easily grown from seed. Pkt. 3 cts.

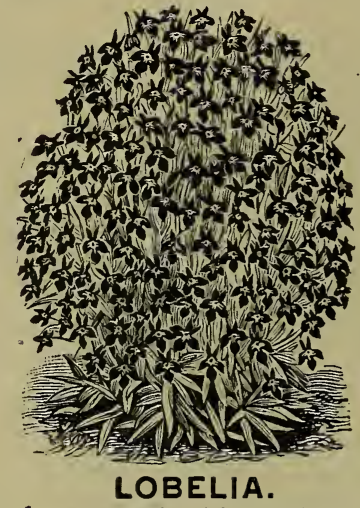

A very valuable and beautiful class of mostly dwarf growing plants; their delicate drooping habit, and the profusion of their charming little blue and white flowers, render then exceedingly ornamental for vases or hanging baskets and rockeries, blooming from June to November, while for border cultivation they are equally effective. Mixed colors. Pkt. 3c.

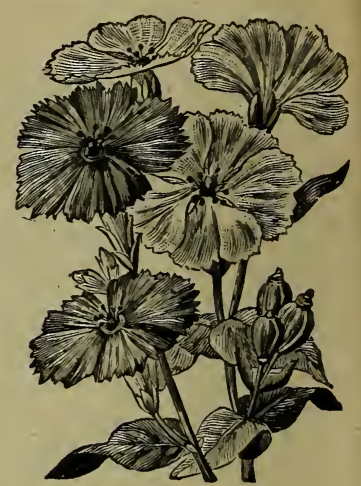

LYCHNIS.

A first-class border plant growing from two to three feet in height, bearing close, symmetrical heads of brilliant scarlet flowers of good size and substance, Sometimes the flowers vary in color, but it is usually of a brilliant scarlet. If sown early in open ground will bloom first season. Pkt. 6 cts. 


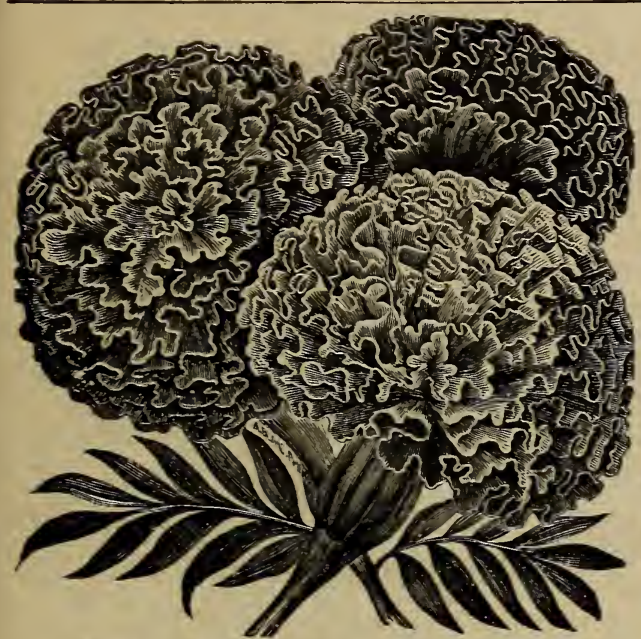

MARIGOLD, THE ELDORADO.

The large, bushy plants are each a ball of brilliant colors, many single plants having seventy-five flowers in full bloom at one time. The flowers are from three to four inches in diameter, most perfectly imbricated, and perfectly double. They embrace four shades of color-the lightest primrose, lemon, golden yellow, and deep glowing orange. Pkt. 3 cts.

\section{MARIGOLD, FRENCH MIXED.}

A class of showy and extremely effective plants, with fine double flowers of rich and beautiful colors; very well adapted for large beds and bordering. No garden should be without them. Will make a grand display wherever planted. Pkt. 3 cts.

\section{NEVER SAW NICER.}

Mrs. W. S. Shaw, Oldham, S. Dak., writes:$I$ had some of your seeds last year and they were all good. I never saw nicer Balsams than I grew from your seeds.

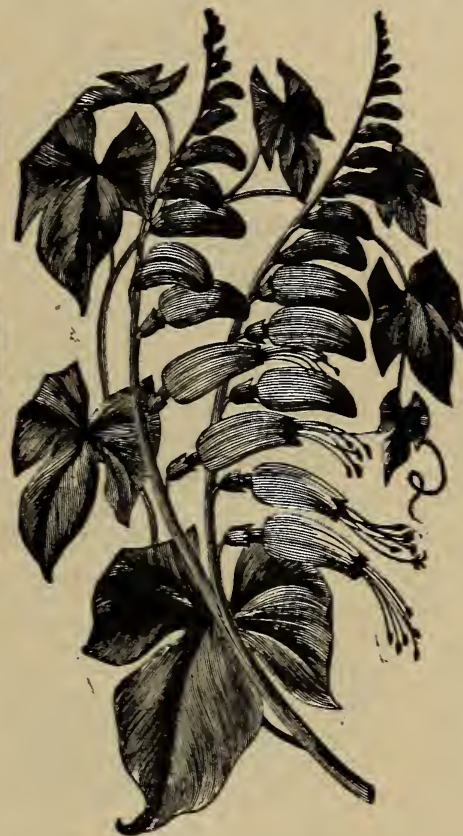

MINA LOBATA.

Half hardy Mexican climbing annual. The buds are at first of vivid red, but turn to orange yellow immediately before they open, and when fully expanded the flowers are of a creamywhite shade. They are freely produced from the base to the summit of the plant, which attains a height of from 18 to 20 feet. Pkt. 6 cts.

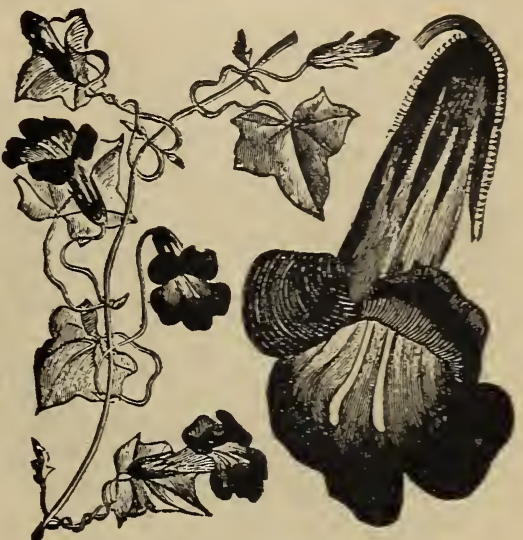

MAURANDIA.

A beautiful rapid, graceful climber for green house, parlor, basket, or outdoor purposes, blooming profusely until late in the autumn, with rich purple, white and rose, fox-glove shaped blossoms and will flower the first season, if sown early. Tender perennial. Pkt. 3 cts.

\section{MIMOSA, (SENSITIVE PLANT.)}

An interesting and curious plant. The leaves will close and droop at the slightest touch, or in cloudy, damp weather and during the night. Graceful fern-like foliage with pink flowers. Iostly grown as a curiosity, not of much value as a flower. Pkt. 3 cts.

BLOSSOMED SO BEAUTIFULLY. Miss Hattie Heath, Moberly, Mo., writes:-As my flower seeds, for Which I sent to you last spring, grew and blossomed so beautifully, I send you another order. 


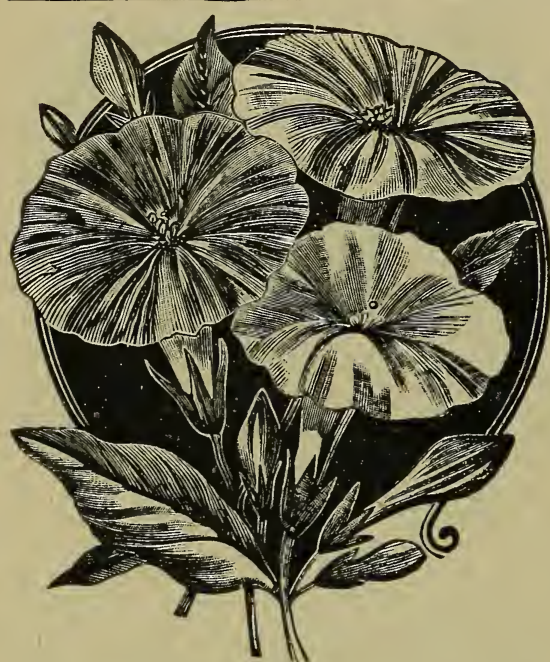

(MARVEL OF PERU, (MIRABILIS.)

A handsome plant both in foliage and flower combined: their colors are vivid and of great variety, the flowers open in the afternoon and are sometimes called the "Four o'Clock." It is one of the most brilliant and showy plants that can be grown with little or no trouble. Pkt. 3 cts.

\section{ALL THAT WAS CLAIMED.}

Miss E. M. Sherwood, 6 Sheridan St., Auburn, N. Y., Writes:-Your seeds last year were all that you claimed for them. I raised some beautiful flowers.

VALDE For your money, when you Flower Seeds at half other a dollar's worth of and the magnificent new Rose, "Madame Testout," FREE. (See page 48 .)

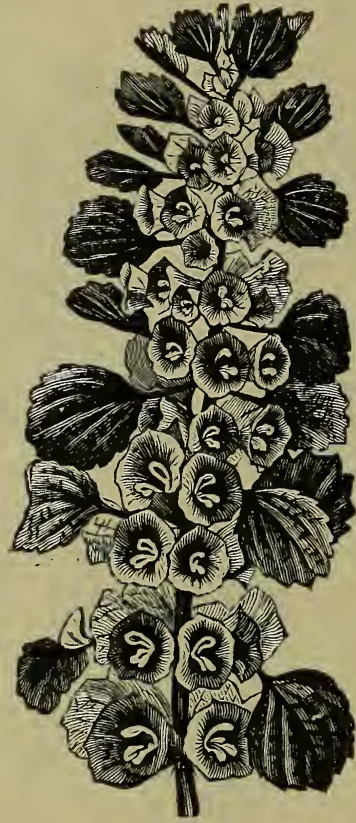

MOLUCCA BALM. (SHELL FLOWER.)

It grows from two to three feet high, sending up a strong central stem, with numerous branches,each of which is so completely surrounded by flowers as to leave scarcely any room for the leaves. The flower is very curious, its large, shell-1ike calyx is green and delicately veined. When cut or broken it emits strong fragrance of balm. Pkt. $4 \mathrm{c}$.

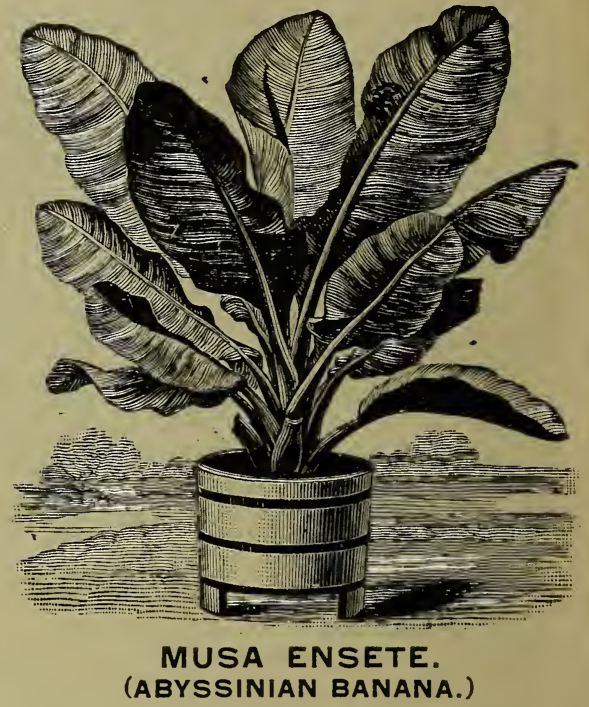

This is one of the grandest and most picturesque of the Banana family; as a solitary plant or in groups on the lawn, it has a very majestic tropical effect. The leaves are very long and broad, of a beautiful green with crimson midrib in striking contrast. If the seed is sown early in hotbeds and repotted several times, the plant will attain a height of orer ten feet the first summer. The rapidity of its growth is astonishing. Pkt. of 5 seeds $14 \mathrm{cts}$.

\section{MUSA MARTINI.}

It is much hardier than Nusa Ensete. The seeds germinate quickly and almost without fail, which cannot always be said of Musa Ensete. This is a most valuable addition to our list of foliage plants for decorations. Pkt. of 5 seeds $12 \mathrm{cts}$. 


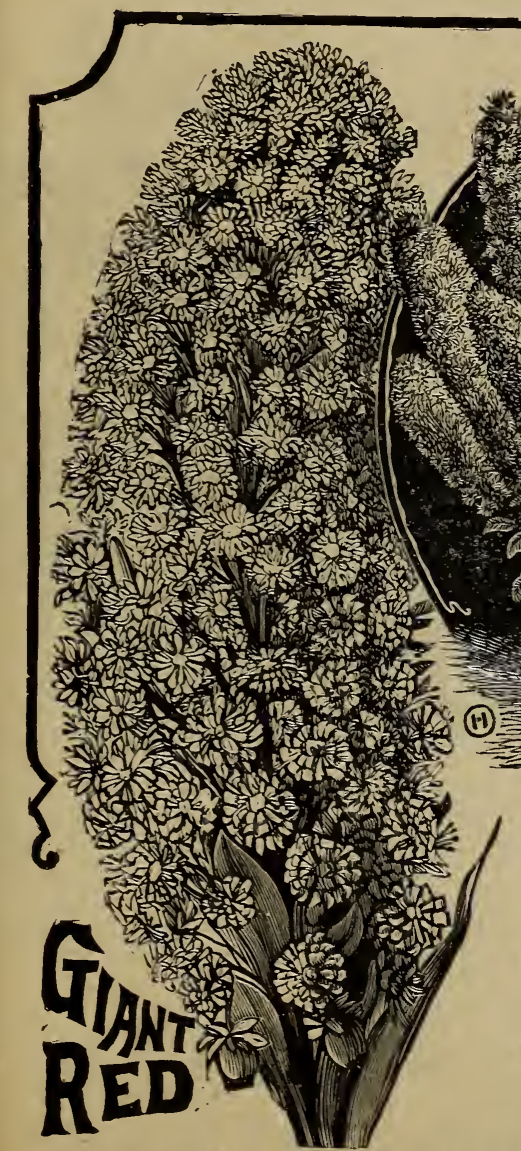

Very fine new variety, with flowers of a golden hue; highly effective; of dense
pyramidal habit and deliciously fragrant. Pkt. 3 cts. MIGNONETTE, SWEET. (RESEDA ODORATA.) A favorite on account of its sweet fragrance. Pkt. 3c.; oz. 10c. 


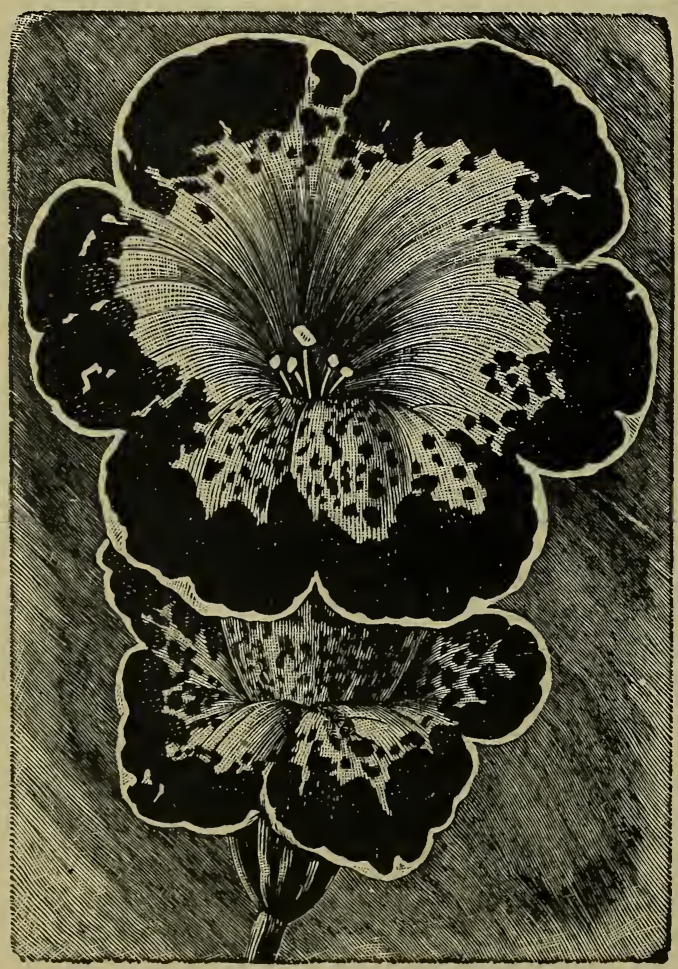

MIMULUS. (MONKEY FLOWER.)

Tender-looking plants, with singularly shaped and brilliantly colored flowers, blotched and spotted in every conceivable manner. Excellent for baskets or vases, while they thrive well in the open garden, if planted in partial shade. Fine hybrid varieties mixed. Pkt. 3 cts.

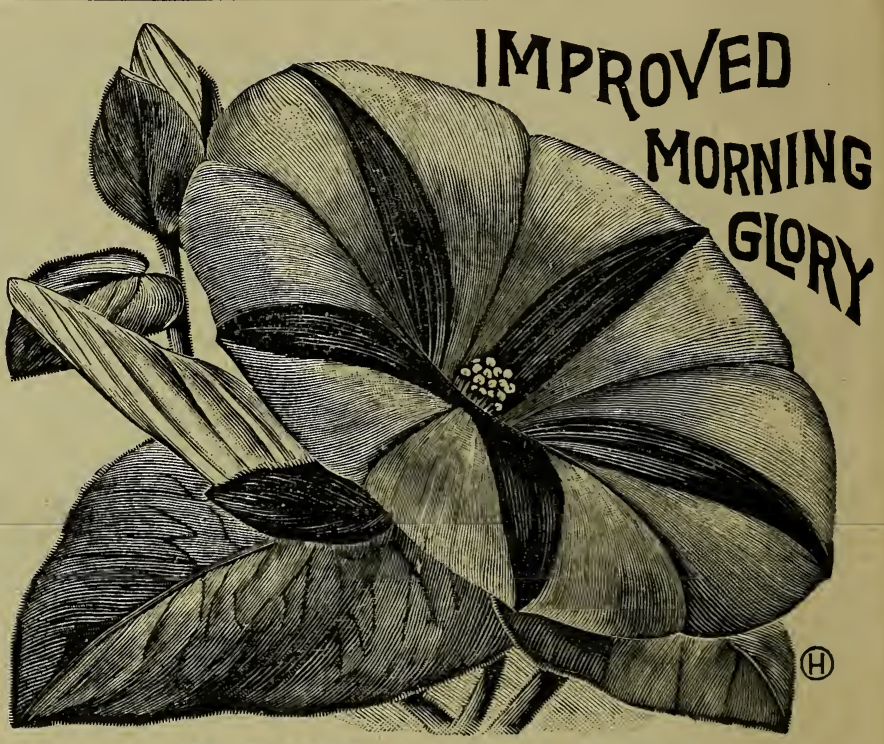

IMPROVED MORNING GLORY.

In looking for beautiful plants, do not overlook the importance of this old, well-known and ever beautiful annual, the "Morning Glory." It is one of the most free-flowering and rapid growing plants in cultivation, and is so hardy as to grow and thrive in almost any soil or situation. The seed is so cheap, the flowers so bright and the vines of such rapid growth that it should be largely planted to cover arbors, windows, trellises, old stumps, etc. All colors mixed. Pkt. 3 cts.; $0 z .8$ cts.

MIMULUS MOSCHATUS. (MUSK PLANT.)

A well-known and favorite plant, both for outside borders and for pot culture in spring. Cultivated on account of the musky odor of the plant. Pkt. 3 cts.

A WELL GRONT Hedge of Sweet Peas is a lavish forgotten when once seen. Get the BEST. (See page 40 .) 


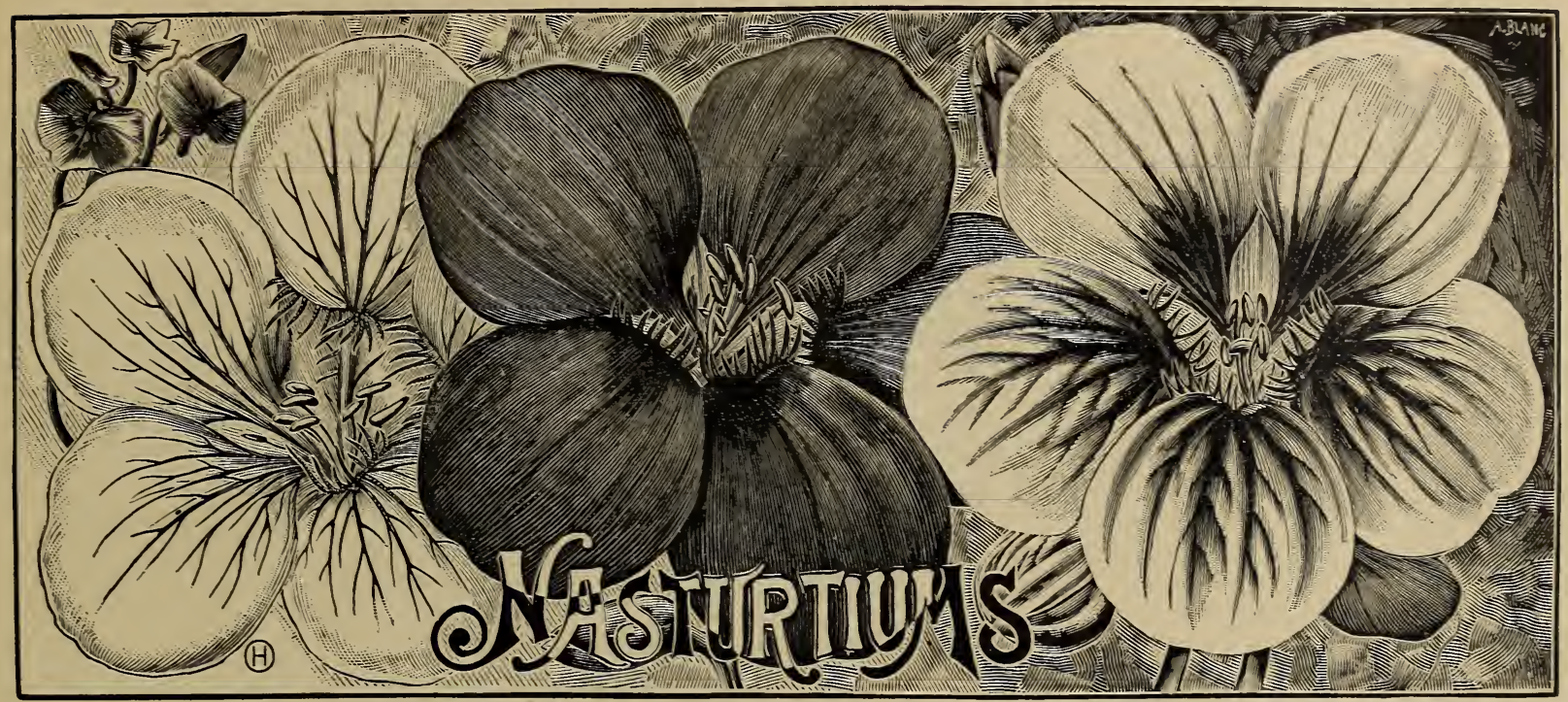

THE BEST Ever produced and not surpassed for gorgeousness of colors and brilliancy of effect, embracing White, Ruby King, New Brilliant Yellow and Spotted King. In Dwarf Nasturtiums I consider my special mixed the best that money can buy, the price may appear high for this strain. but it is made up especially for critical buyers that have the money to spend for THE BEST ONLY. Price, large Pkt. 8 cts.; 0z. 25 cts.

DWRRF NASTURTIUMS-many varieties mixed, the same grade as is usually sold, and very good. Pkt. $3 \mathrm{c}$.; $0 \mathrm{z}$. $10 \mathrm{c}$.

\section{TALL NASTURTIUMS, BEST.}

I also offer a special mixture of the Tall, or climbing Nasturtiums, made up on the same basis as the Dwarf variety described above, from the best named and brightest colors only. Large Pkt. 8 cts.; $0 z .20$ cts.

TALL NASTURTIUMS-many varieties mixed, good quality. Pkt. $3 \mathrm{cts,;} \mathrm{0z,} 10 \mathrm{cts}$.

WORTH TWICE THE PRICE. Mrs. Timothy Smith, Durand, Mich., writes:-I was very much pleased with the collection of seeds that $I$
received from Joulast spring. The Balsams and Pinks were worth twice the price of the entire collectionthey were just lovely. 


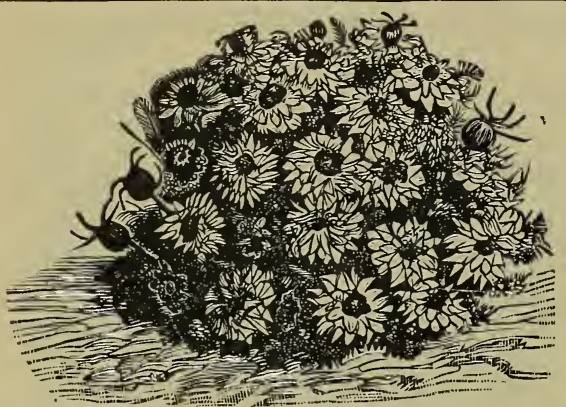

NIGELLA, LOVE-IN-A-MIST.

Hardy annual known as "Devil-in-Bush" and "Lady-in-Green," because the blossoms are partially concealed by the abundance of finely cut foliage. The plant and flower are both handsome, and require but little care. Pkt. 3 cts.

\section{OXALIS.}

Exceedingly free flowering little plants with lively foliage and entirely covered with bright flowers from June until Sep tember. It is not generally known that these annual varieties of Oxalis are fully equal for edgings to the varieties grown from bulbs. Mixed colors. Pkt. $3 \mathrm{cts}$.

\section{OENOTHERA.}

(EVENING PRIMROSE.)

Acaulis Alba. Saucer-shaped, silverywhite flowers of enormous size, often as large as a Moonflower; very striking and fragrant. Plant almost stemless, the leaves lying close to the ground. Pkt. 3c.

FRESH AND RELIABLE.

Mrs. R. T. Gayden, Winona, Miss., writes -Your Flower Seeds are fresh and re liable and gave much satisfaction, hence my order this spring, with best wishes for your success.

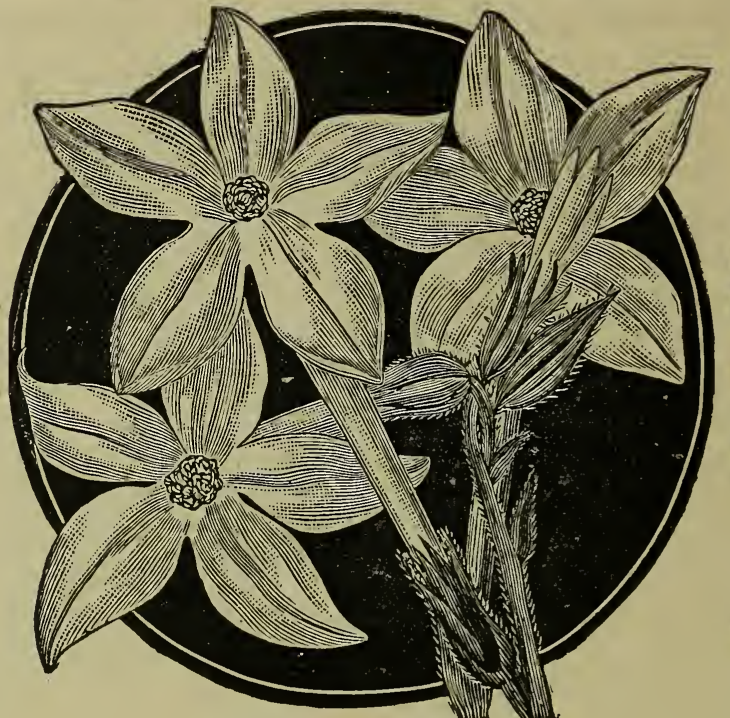

NICOTIANA AFFINIS.

When its large, pure white flowers are fully expanded in the evening and early morning, it has a most striking effect and so fragrant that a small bed will perfume the whole surrounding atmosphere. If the plants are taken up in the fall, cut back, and potted, they will bloom freely all winter in the house. Pkt. $6 \mathrm{cts}$.

\section{NICOTIANA COLOSSEA. (GIANT TOBACCO PLANT.)}

This new Tobacco Plant grows to the height of 9 feet, the leaves grow 3 feet long with a diameter of 20 inches. The stalk being red contrasts very plf asingly with the dark green foliage. It is most effective as solitary plant on the lawn and also in combination with other foliage plants. Pkt. $12 \mathrm{cts}$.

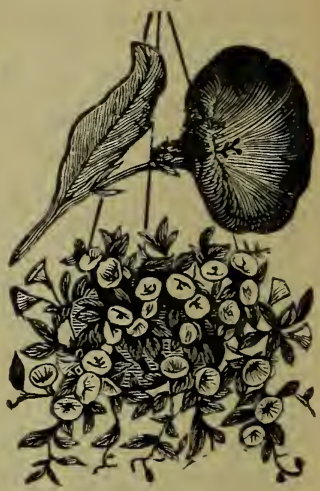

NOLANA.

Beautiful trailing plants, almost equal to the Portulaca for growing in masses, and unsurpassed for baskets, pots, vases or rock work. The flower is similar in shape to a Morning Glory and of various colors. Pkt. 3 cts.

\section{AN OUNGE}

Of Dwarf Nasturtium seed will be sufficient for a bed ten feet in diameter, and will make a better display for three months, than almost any other plant. (See page 29.)

Fll Cultura 1 UL Directions be sent on request. 


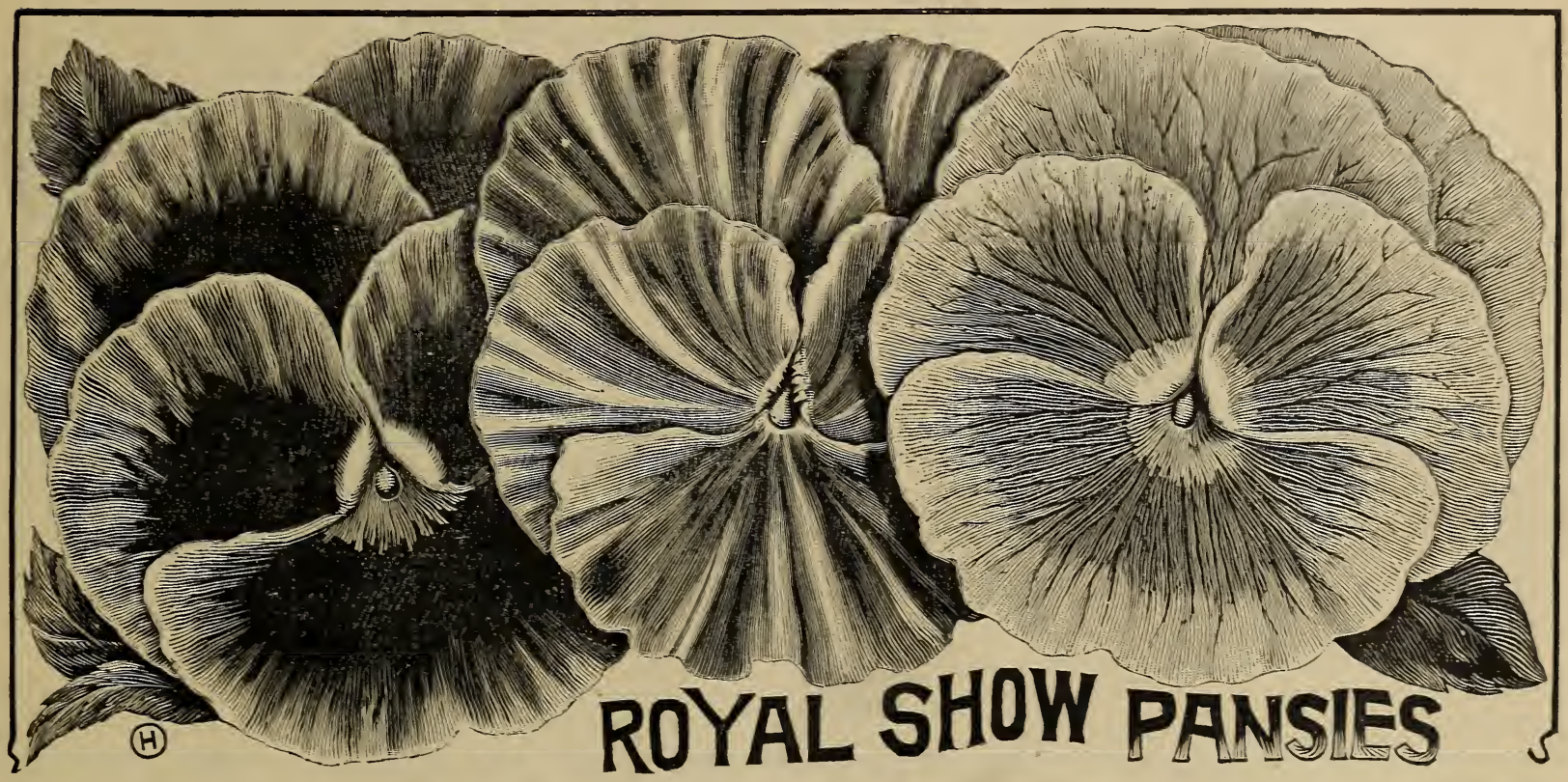

The Royal Show Pansies produce flowers of the largest size, most perfect shape and richest colors, which, for variety and beauty cannot be excelled. The flowers are half as large a gain as ordinary Pansies, frequently measuring two-anda-half to four inches across. The colors a re truly wonderful and include all the new shades and markings introduced to the present time, The mixture is especially prepared for the most critical pansy lover and florist who require the greatest variety of colors, as well as flowers of the largest size. There is no flower capable of adapting itself to our climate that can be more truly called an "ever-blooming" flower. Price Pkt. (50 seeds) 8 cts.; Pkt. (100 seeds) 12 cts.

\subsection{IN GASH PRIZES}

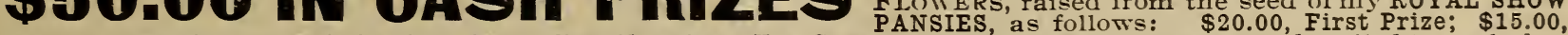
Second Prize; $\$ 10.00$, Third Prize; $\$ 5.00$, Fourth Prize. The flowers must be carefully pressed and mailed to me before Oct.1st, 1891, with the name and full address of the sender on back of "Competition Card," which accompanies each order for either an 8c. or 12c. packet of the "Royal show," and the prizes will be immediately awarded the successful competitors. In case there are several flowers received of exactly the same size, BEAUTY AND JIARKINGS of the flower will take first place. Competition open to all as I wish to see how large a Pansy can be grown. 


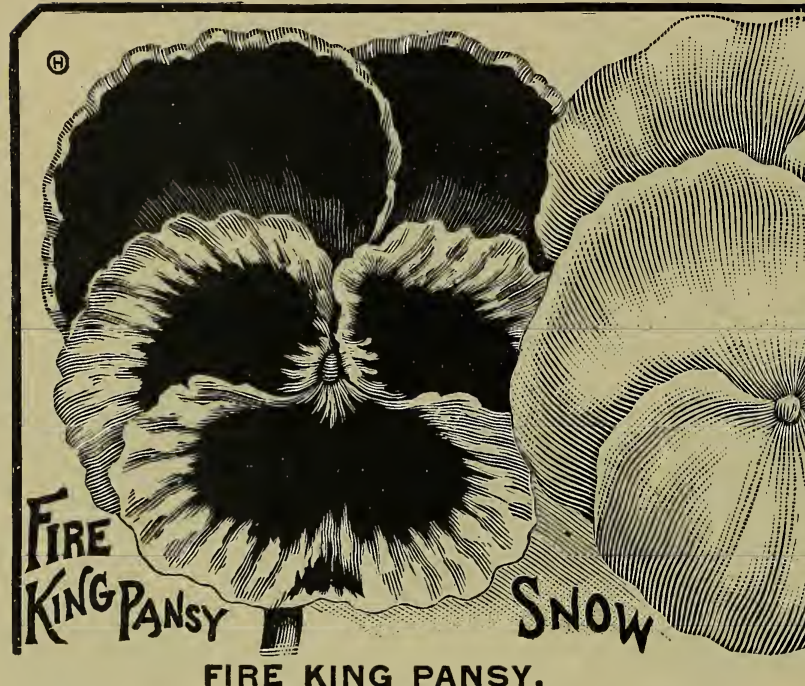

FIRE KING PANSY.

This novelty comes almost absolutely true, scarcely a plant bearing flowers at variance from the type, which is very distinct and striking. The three lower petals each have a large blotch of deep brown-red or magenta margined with yellow, while the upper petals are of a bright reddish-brown, of a real fiery shade, warranting the name FIRE KING. Pkt. 6 cts.

\section{SNOW QUEEN PANSY.}

Pure satiny white with yellow dot in center of flower, sometimes marked near center with faint blue or purple lines; altogether the least picturesque of any of the different classes of Pansies, it is very highly prized by a great many pansy lovers for just that reason. Pkt. $6 \mathrm{cts}$.

\section{ECKFORD'S PRIZE PANSY.}

A surperb cross-fertilized mixture of surperior excellence, comprising some of the most lovely varieties of this favorite flower- The colors are brilliant and novel, also recommended for size and beauty of form. Pkt. $8 \mathrm{cts}$.

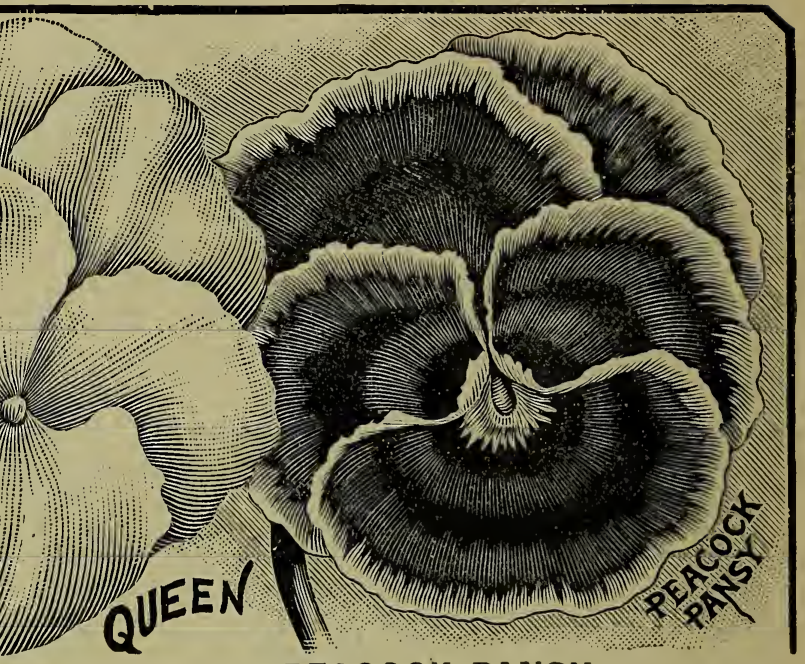

PEACOCK PANSY.

A beautiful variety of ultra-marine blue in the upper petals of the flower, edged with a thin white line, within which, is a space of purplish-crimson, passing into a rich central blotch of deep blue, shading to black, named "Peacock," because the blending of colors resemble the feathers of a peacock. Pkt. $6 \mathrm{cts}$.

\section{NEW IMPERIAL GERMAN PANSY.}

This mixture embraces seed of over fifty colors and markings and is guaranteed to equal any strain offered as Imperial German. While this mixture contains the choicest colors and greatest variety, the flowers, in some colors, are of medium size only. Pkt. $6 \mathrm{cts}$.

\section{NEW GIANT PANSY.}

Remarkable for the extra large size of the flowers, which, however, are not so circular in form as the "Imperial German," or the "Fancy" and "Show" flowers, as in the "Royal Show," as offered on page 31 . Pkt. 8 cts.

PANSY-good mixed. Pkt. 3 cts. 


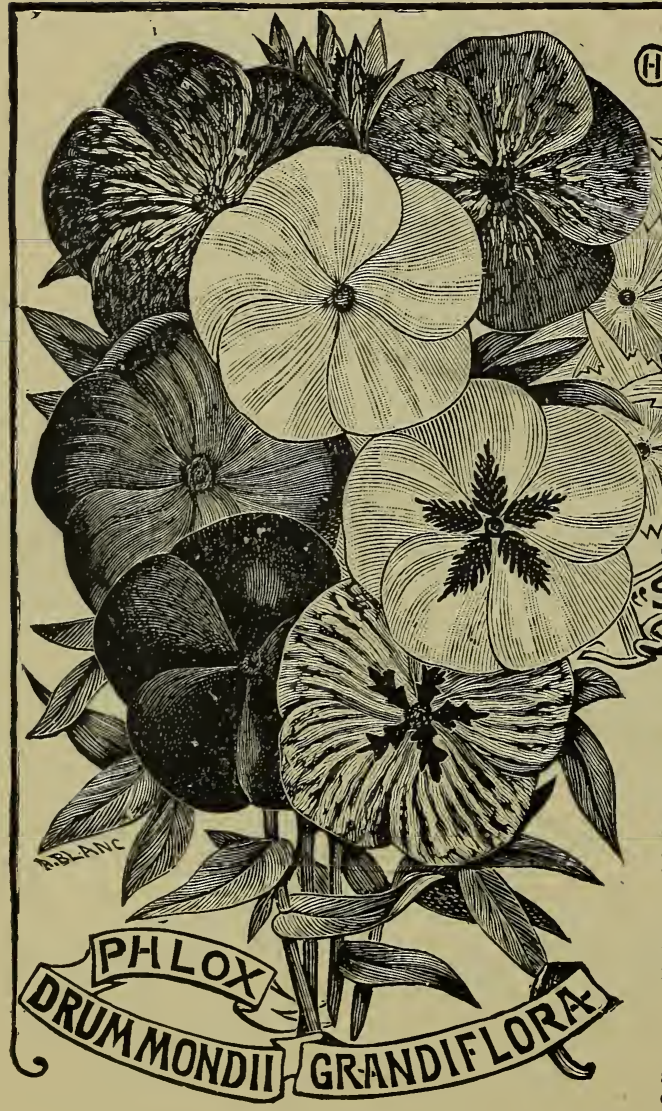

(1)

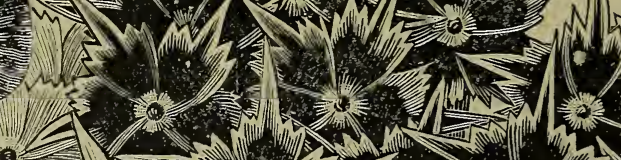
a
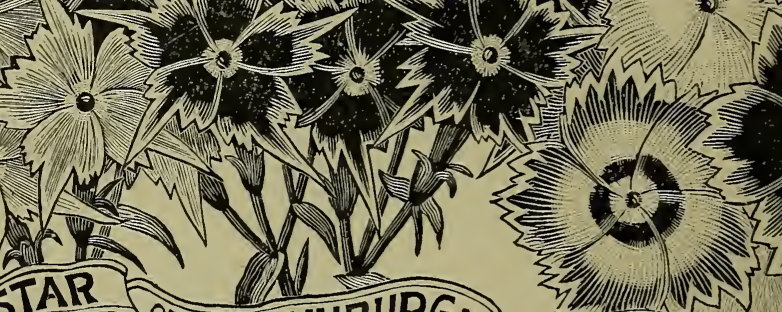
STAR OQFUEDLNBURG:

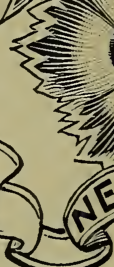

PHLOX DRUMMONDII GRANDIFLORA.

Their long duration in bloom, combined with their almost unequalled richness of color, renders them of invaluable service in the flower garden, and a finer sight than a bed of Phlox Drummondii is rarely to be seen. The colors range in every conceivable shade. Pkt. 4 cts. Extra large Pkt. 6 cts.

\section{STAR OF QUEDLINBURG PHLOX.}

This unique variety is of extraordinary character, the flowers appear to have a star-like fornı, thus producing a most brilliant effect, finest mixed from over 20 colors. Pkt. 6 cts.

\section{NEW FRINGED PHLOX.}

A distinct variety of great beauty, the petals being partly fimbriate. and partly three-toothed, all distinctly bordered with white, over 20 distinct sliades mixed. Pkt. 6 cts.

PHLOX DRUMMONDII-good mixed. Pkt. $3 \mathrm{cts}$.

PHLOX, PERENNIAL-choicest mixed. Plit. 6 cts. 


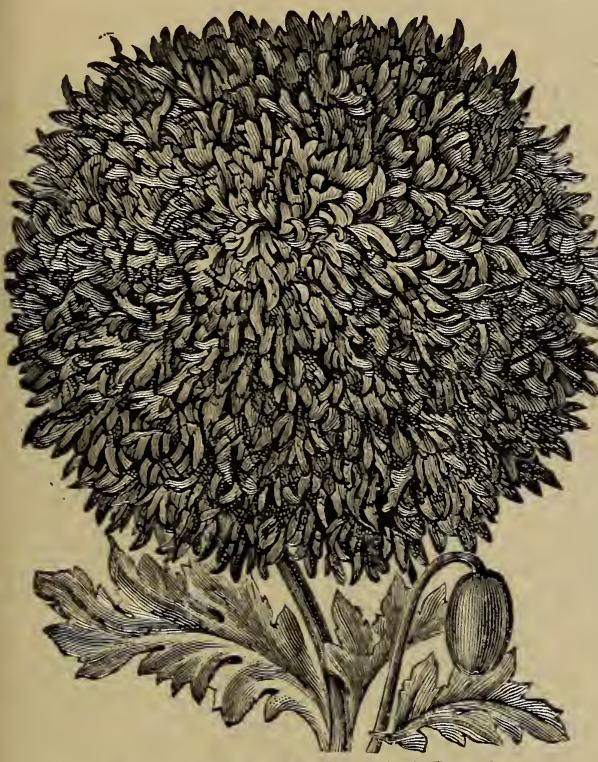

NEW CARDINAL POPPY.

The dwarf, very robust, and compact habit of growth of this new Poppy makes it entirely distinct from most other double Poppies. The plants grow about sixteen inches high, and are well furnished with deeply cut dark-green foliage, which shows off the enormous, double, glowing, cardinal-scarlet flowers. On close inspection, each of the perfectly fringed petals will be found finely lined with white, while on the back of the flower a white Maltese cross stands out in sharp relief. Pkt. $6 \mathrm{cts}$.

YES Single Dahlias surpass by far from seeds the first season. Get a packet and try them.

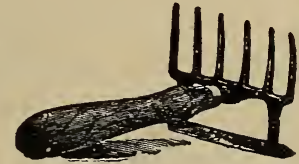

THE COMBINATION WEEDER.

Combining as it does both the rake and hoe, it is the most serviceable, durable and perfect weeder on the market. It is especially adapted to cutting weeds and grass, shallow cultivation and stirring of the soil of all garden crops, flower beds and nursery stock that requires hand cultivation in the early stages of growth. It is neatly and strong$1 y$ made of malleable iron (tinned) and the blade of the best spring steel, sharpened on both edges and points, which allows weeding close to the plants. Everyone who has garden, large or small, should have the combinationWeeder. Guaranteed to give satisfac tion. Price, only $28 \mathrm{c}$. postpaid. Not allowed to be selected as premium.

VERY RESTFUL

Mrs. M. F. Runiman, Hartland, vt., writes:Your Catalogue is very restful. Hoping you will be ever abundantly prospered.

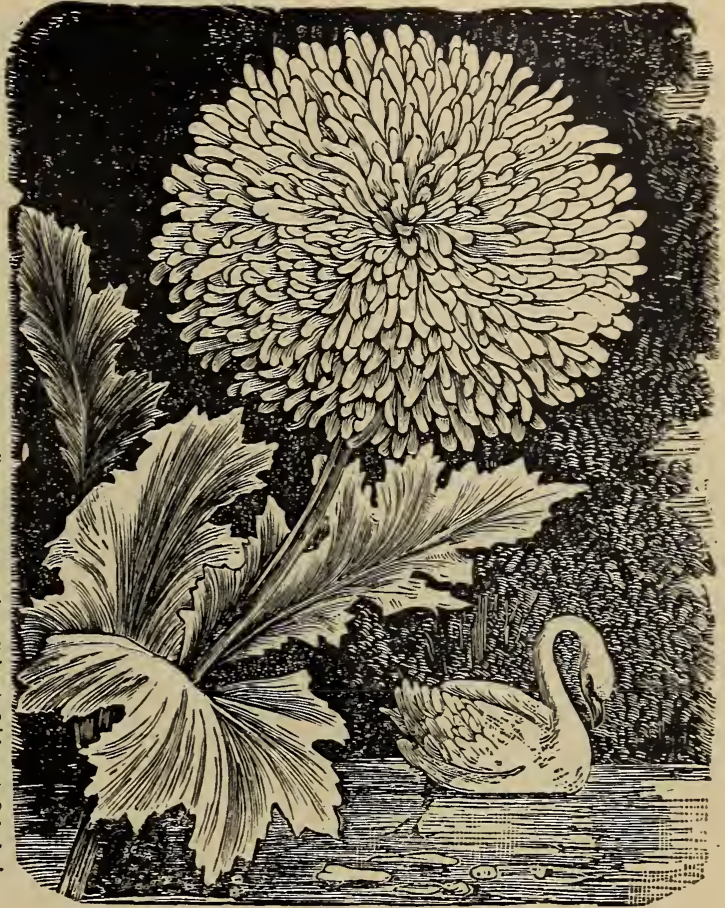

\section{NEW POPPY, WHITE SWAN.}

One of the most effective and valuable Poppies introduced for years. The plants are about 18 inches high. grow in very pretty bush form crowned with flowers of enormous size, perfect form, very double and of the purest snow-white. Its flowering period is considerably longer than that of other Poppies. Pkt. $6 \mathrm{cts}$. 


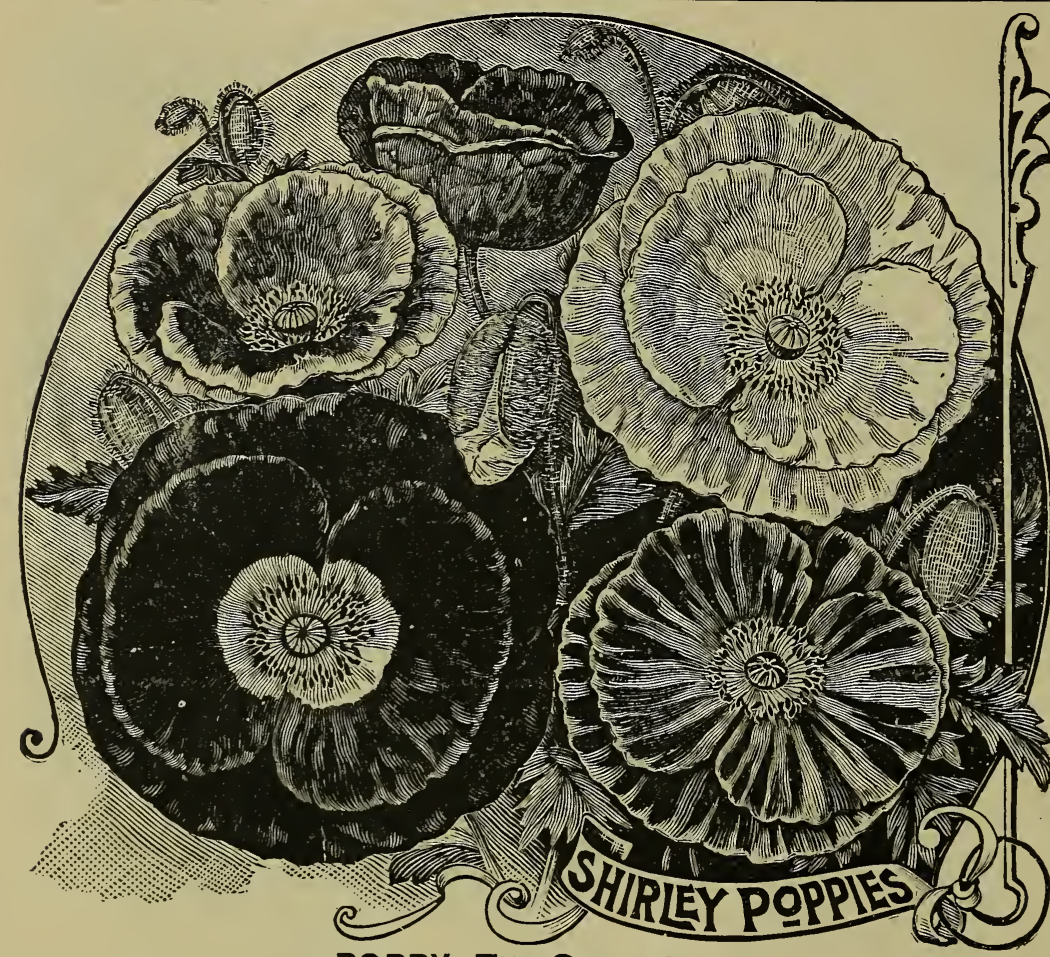

POPPY, THE SHIRLEY.

It is perfectly hardy and flowers the first season from seed. The flowers are large, exceedingly graceful, and elegant; the colors are pure, soft and varied, and range from bluish-white rose, delicate pink and carmine, through innumerable tints to bright, sparkling crimson. Pkt. 4 cts.

"MULTUM IN PARVO."

Mrs. Cora L. Woods, Milan, N. H., writes - IVhat a lovely little Catalogue-so small and yet it tells so much

\section{TULIP POPPY.}

A magnificent new species 12 to 14 inches high, each plant producing 40 to 60 scarlet flowers much resembling, in both shape and color, scarlet Duc Van Thol tulips. The two outer petals form a saucer surrounding two erect petals, giving a very unique and handsome appearance. They in uninterrupted succession for several weeks. When the flowers begin to fade two black spots are visible at the base of the petals. Pkt. 6 cts.

\section{DOUBLE POPPIES MIXED.}

For dazzling richness and variety of colors, the flowers are unequalled. Simply scatter the seed in the open ground and a mass of beauty will result, which will be a constant source of pleasure. Pkt. 3 cts.

HONESTY THE BEST POLICY. Mrs. E. W. Turner, Newton Falls, Onlo, writes:-I am much pleased with the appearance of your modest little cataappearance of your modest little catamany showy catalogues, with overdrawn pictures and so much said calculated to mislead, that I feel disgust ed and wonder why men cannot see that honesty is the best policy, and it would be a credit to the trade, in bringingout novelties, to occasionally tell the cruth.

\section{MORE AND BETTER SEEDS.}

Mrs. A. Elder, Princeton, Kan., Writes :I ordered seeds from you last year and certainly shall not patronize any one else, for $I$ think $I$ get more and better seeds for the money than from any other firm.

THE PAMSY Is a popular flower 1 HIS giving an abunáthe finest strain, grow "Royal Show." (See page 31$)$, $\$ 50.00$ in CASH PREMIUNS. 


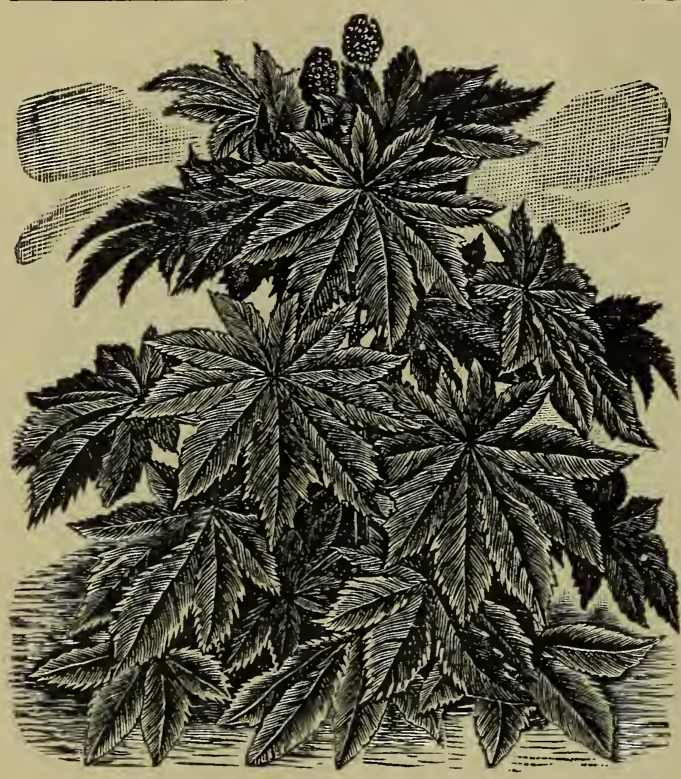

RICINUS, CAMBOGIENSIS. (CASTOR-OIL-BEAN.)

Grows from 6 to 8 feet high in a few weeks from time of planting, with large palm-like leaves of a brilliant, bronzy-red maroon color, with large red veins. The leaf, stems and younger growth are of rich reddish brown, while the main stem, or trunk, is of ebony black. It is one of the finest plants for tropical effects, either in masses or as single specimens, on the lawn or garden. Pikt. 6 cts.

RICINUS (CASTOR - OIL - BEAN) - many choice varieties mixed. Pkt. 3 cts.

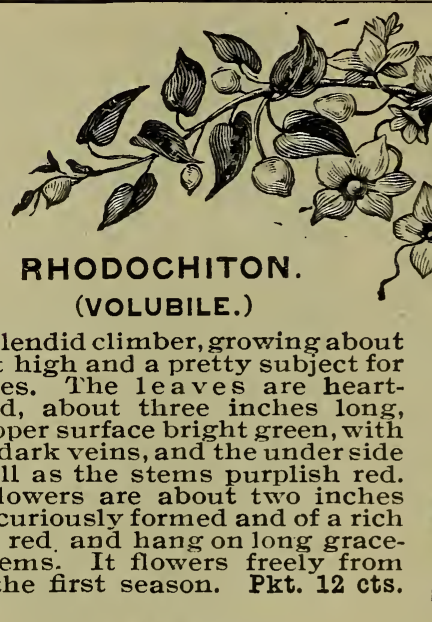

\section{MOTHER-IN-LAW.}

Mrs. L 111 ie McCormick, Furley, Kans., writes:-Last year" Mother, (in-law), Mrs. E. M c Cormick,", sent for your collection and gave my name. Nothing could have given me more pleasure or better satisfaction than the seeds she received. I wish you much success and prosperity.

\section{" SWEET FAITHFUL.'}

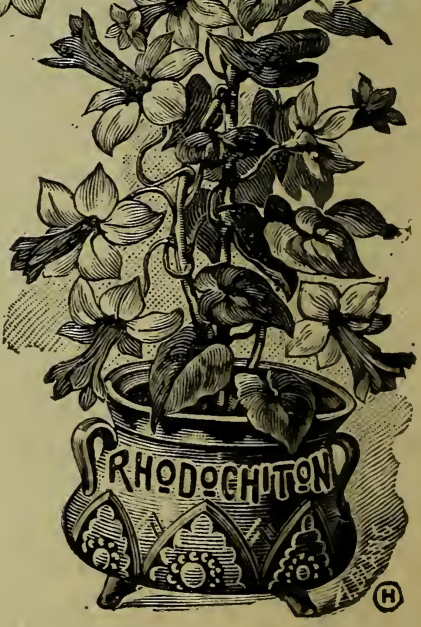

Florence B. Brown Springville, $\mathrm{Ky}$ writes:- I was very much pleased with the Seeds you sent me last spring: nothing. however, gave me so much pleasure as my small bed of Sweet Alyssum; wherever I went among my flower beds, all through the summer until late in the fall, I was greeted with a mass of dainty white blooms and delicate odor of Sweet Alyssum. I think it should be called "Sweet Faithful."

EYERY:ONT loves and wants a fine rose. (See page 48) variety, "Nadame Testout," Fou can get the magnificient new 


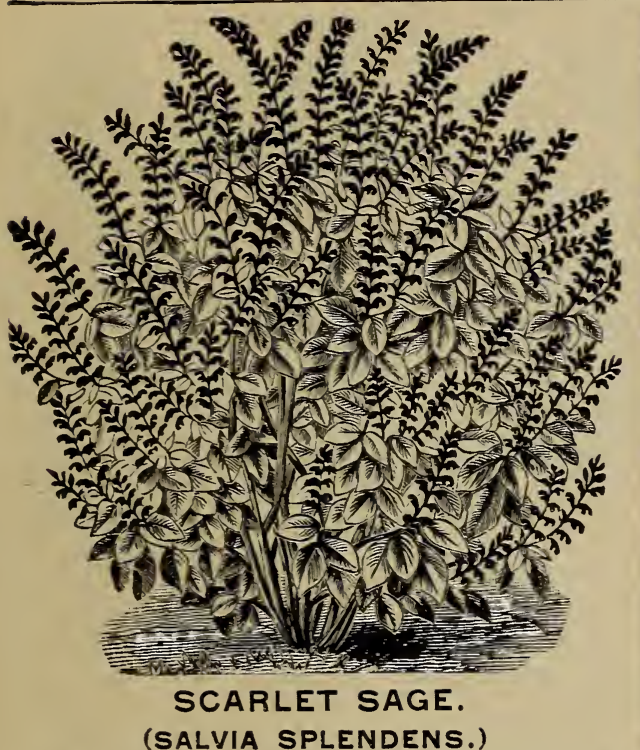

One of the grandest plants in cultivationa bed of them surpassing the finest scarlet gera:iums in brilliancy and continuous bloom, the flower spikes often measure 10 to 12 inches in length, and there are as many as two hundred spikes on a well grown plant. From the time they first begin to flower, the plants are never out of bloom until killed by late frosts. It is easily grown from seed and the purchase of plants should be abandoned. Pkt. 4 cts.

\section{SALVIA FARINACEA.}

The plants form dwarf, compact bushes, with long spikes of beautiful blue flowers which makes a charming contrast when grown with the scarlet, described above. Pkt. 6 cts.

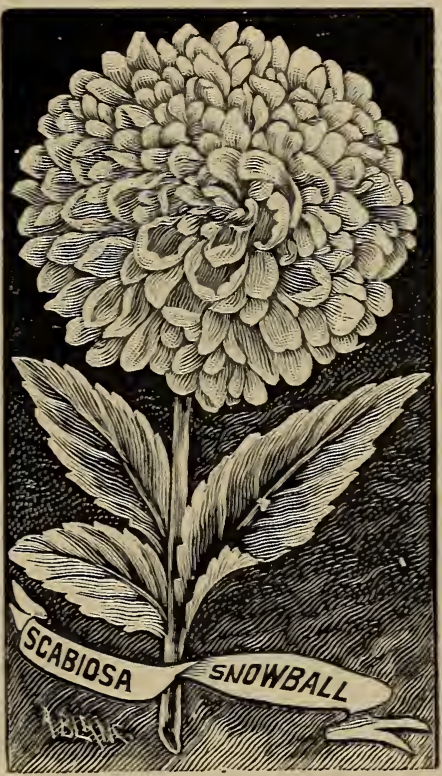

SNOWBALL SCABIOSA.

The flowers are very large, measuring fully two inches in diameter, of purest white and very double, It comes quite true from seed. Pkt. 6 cts.

\section{DOUBLE BLACK} SCABIOSA:

A new variety with elegant double black-purple flowers-so deep in color as to a ppear nearly coal-black. Pkt. 6 cts.

SCABIOSA-mixed, Pkt. 3 cts.

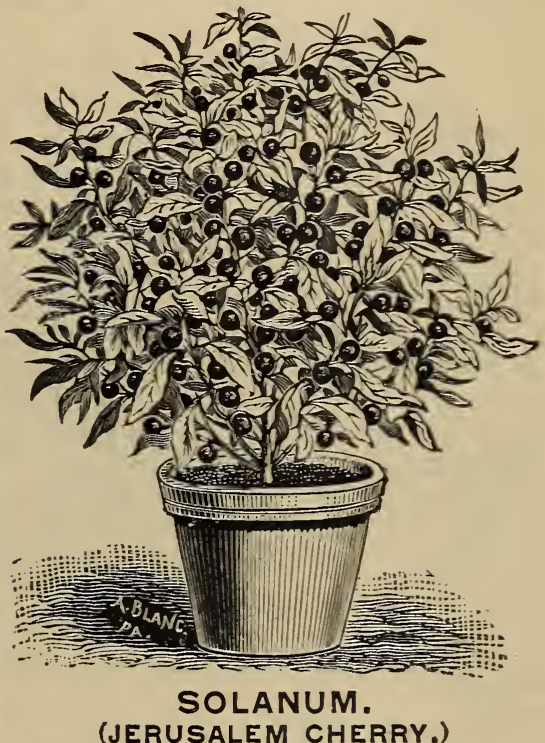

A miniature orange tree, covered all winter with a profusion of scarlet fruit. The foliage is very beautiful, but the fruit is the chief attraction, Pkt. 4 cts.

10011 For beautiful window garden in winter, or any other time, for that matter, do not over-1ook the importance of the old, well-known and ever beautiful annual, the "Morning Glory." It is especially adapted for a house plant.

PERFECT SATISFACTION.

Mrs. J. H. Ross, Hardwick, Mass. writes:-Your seeds gave me perfect satisfaction last year. 

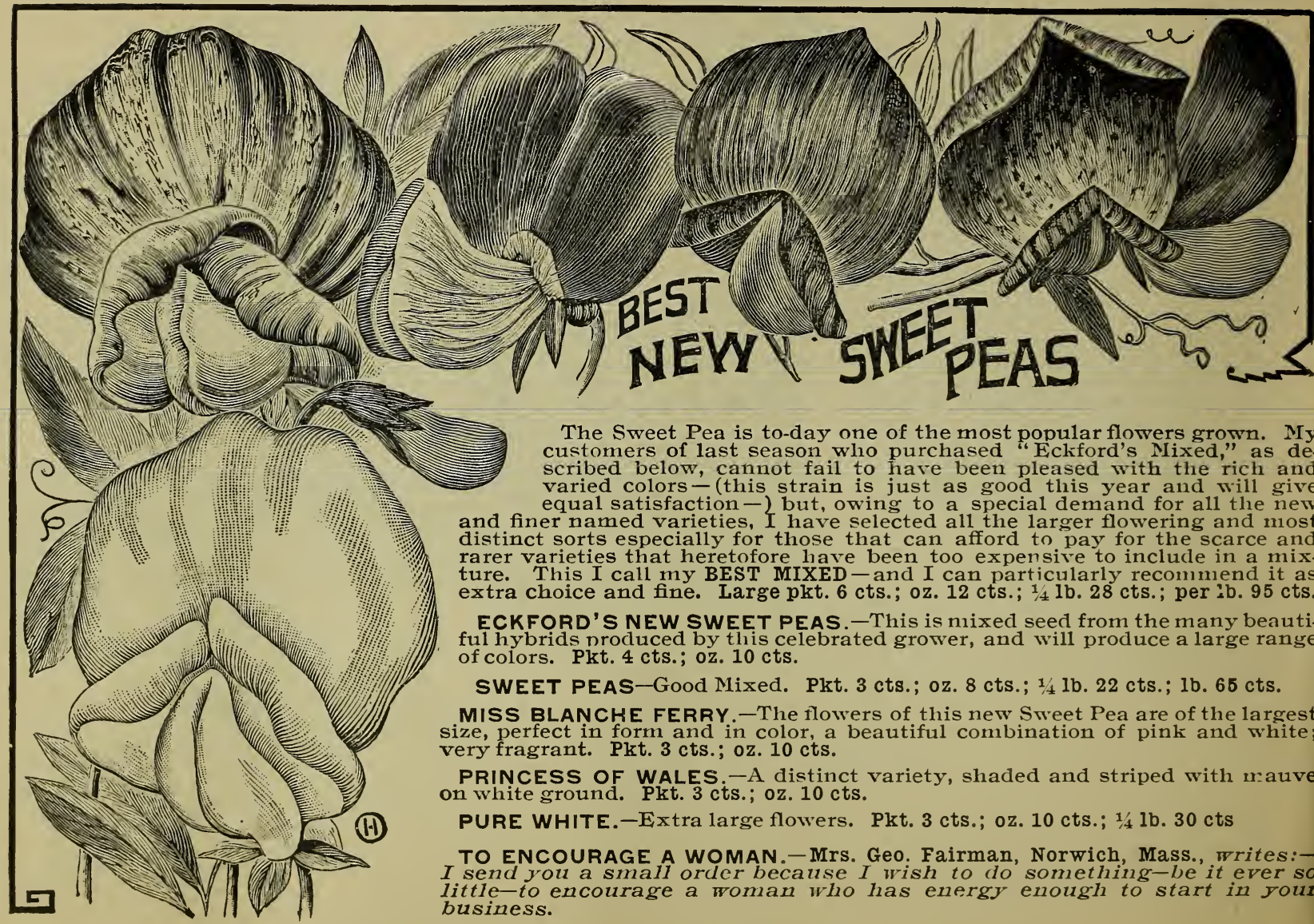

The Sweet Pea is to-day one of the most popular flowers grown. My customers of last season who purchased "Eckford's Mixed," as described below, cannot fail to have been pleased with the rich and varied colors - (this strain is just as good this year and will give equal satisfaction -) but, owing to a special demand for all the new and finer named varieties, I have selected all the larger flowering and most distinct sorts especially for those that can afford to pay for the scarce and rarer varieties that heretofore have been too expensive to include in a mixture. This I call my BEST MIXED - and I can particularly recommend it as extra choice and fine. Large pkt. 6 cts.; 0 z. 12 cts.; $1 / 41 \mathrm{~b} .28$ cts.; per 1 b. 95 cts.

ECKFORD'S NEW SWEET PEAS.-This is nixed seed from the many beautiful hybrids nroduced by this celebrated grower, and will produce a large range of colors. Pkt. 4 cts.; oz. 10 cts.

SWEET PEAS-Good Mixed. Pkt. 3 cts.; $0 \mathrm{z} .8 \mathrm{cts}$; $1 / 41 \mathrm{lb} .22 \mathrm{cts}$.; $1 \mathrm{~b} .65 \mathrm{cts}$.

MISS BLANCHE FERRY.-The flowers of this new Sweet Pea are of the largest size, perfect in form and in color, a beautiful combination of pink and white; very fragrant. Pkt. 3 cts.; $0 z .10$ cts.

PRINCESS OF WALES.-A distinct variety, shaded and striped with mauve on white ground. Pkt. 3 cts.; oz. $10 \mathrm{cts}$.

PURE WHITE.-Extra large flowers. Pkt. $3 \mathrm{cts.;} \mathrm{oz.} 10 \mathrm{cts}$; $1 / 4 \mathrm{lb} .30 \mathrm{cts}$

TO ENCOURAGE A WOMAN.-Mrs. Geo. Fairman, Norwich, Mass., writes:$I$ send you a small order because I wish to do something-be it ever so little-to encourage a woman who has energy enough to start in your business. 


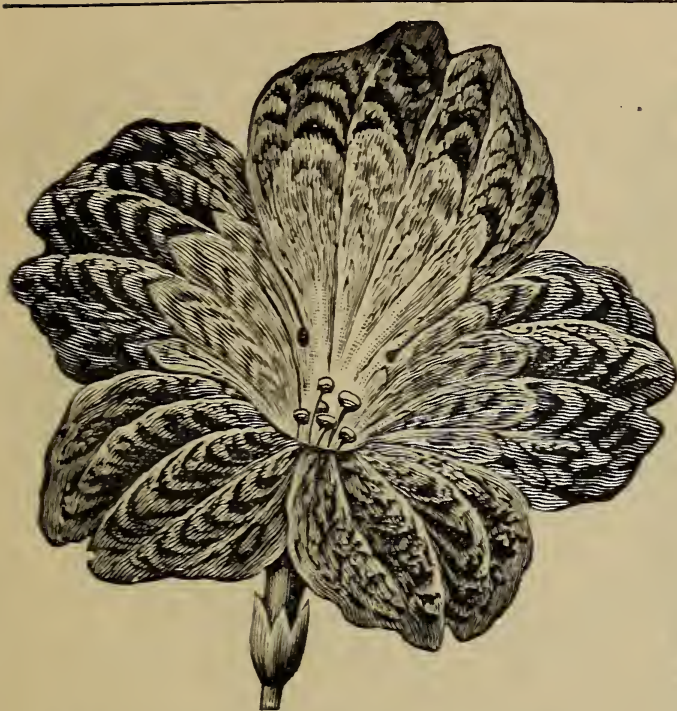

SALPIGLOSSIS, GRANDIFLORA.

The graceful flowers, borne on long stems, range in color from the most delicate shades of light blue and straw color to the deepest purple and richest brown and maroon. The quaint funnel-shaped flowers somewhat resemble those of the petunia, and are borne on long stems in great profusion. The metallic gloss and distinct reinings of the petals present almost the appearance of jeweled enamels. Large Flowering Mixed, Pkt. 4 cts.

\section{A VERY UNIQUE CATALOGUE.}

Miss Rhoda G. Houtz, 116 Manning St., Hillsdale, Mich., writes: $-I$ received a very little unique catalogue a few weeks aoo, and its neatness so took my eye, and its low prices so met my approval, that I determined to send for list of Seeds wanted.

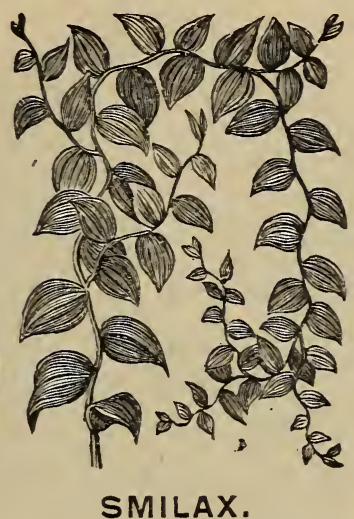

One of the most desirable window vines on account of its charming, glossy green, elegant and graceful foliage, and will grow several feet high the first season. Started in the spring it affords elegant trellis plants for the house in winter; also fine for hanging baskets. Pkt. 6 cts.

\section{MAY YOU EVER PROSPER.}

Mrs. Cora Eich, Tonica, Ills., Writes:-I raised a beautiful lot of flowers from the Seeds bought of you last year, and mist say, $I$ ar surprised you can send so many for so little moner. May you ever prosper in your good Work.

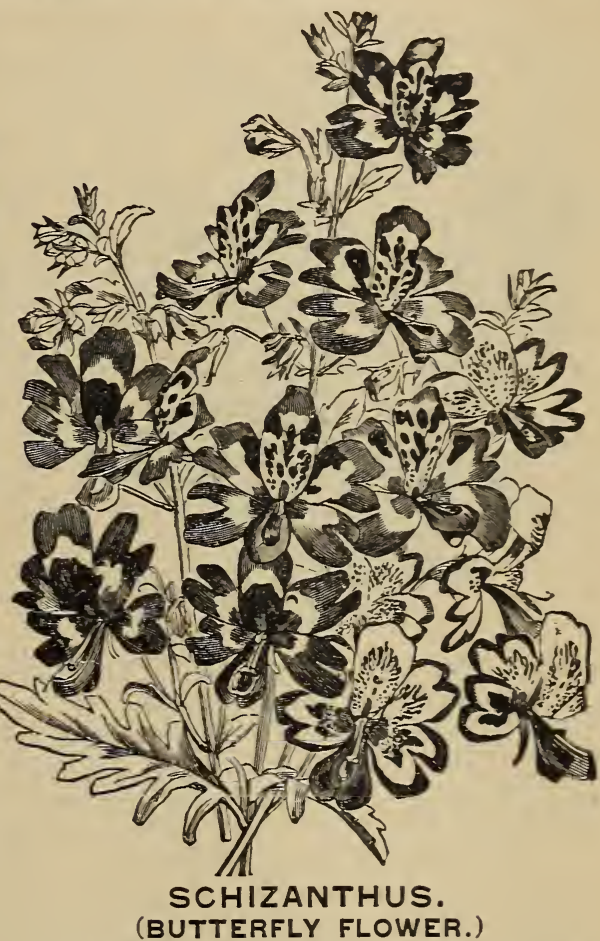

Elegant and rery free blooming annuals of much interest and beauty, and when well grown, rival in singularity of colors and markings the orchids, large flowers spotted with crimson. lilac, purple and yellow, and the petals are cut in a picturesque manner. In pots in the conservatory or house few plants are more attract ive; also elegant in a bouquet or vase, and fine for bedding. Pkt. $3 \mathrm{cts}$. 


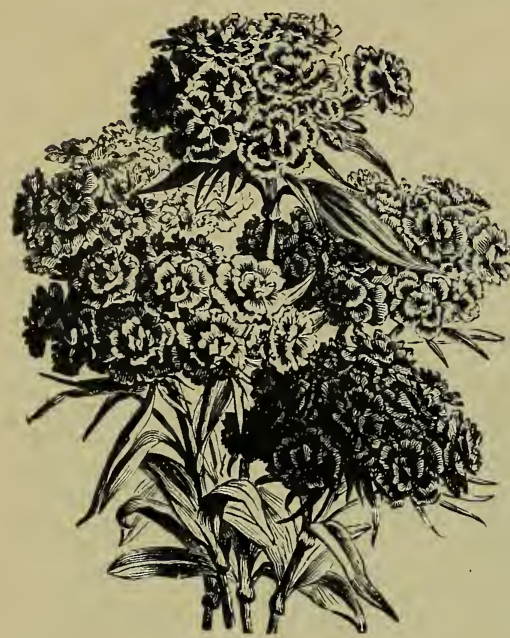

SWEET WILLIAM.

(DIANTHUS BARBATUS.)

Matchless border plants, flowers of many bright colors and varied markings, including the finest auriculaeyed varieties. Single and double mixed. Pkt. 3 cts.

STOCKS, TEN WEEKS.

New Largest Flowering Globe Pyramidal. Immense spikes of perfectly double flowers, pyramidal in shape, the individual blooms frequently measuring from 2 to $2 \frac{1}{2}$ inches in diameter, ranging in colors from crimson, rose, white, blue, lilac, brown and yellow. They are greatly prized for cut flowers on account of their fragrance and diversity of colors. Pkt. 6 cts.

STOCKS, Dwarf German Ten-Weeks. Fine mixed. Pkt. $3 \mathrm{cts}$.

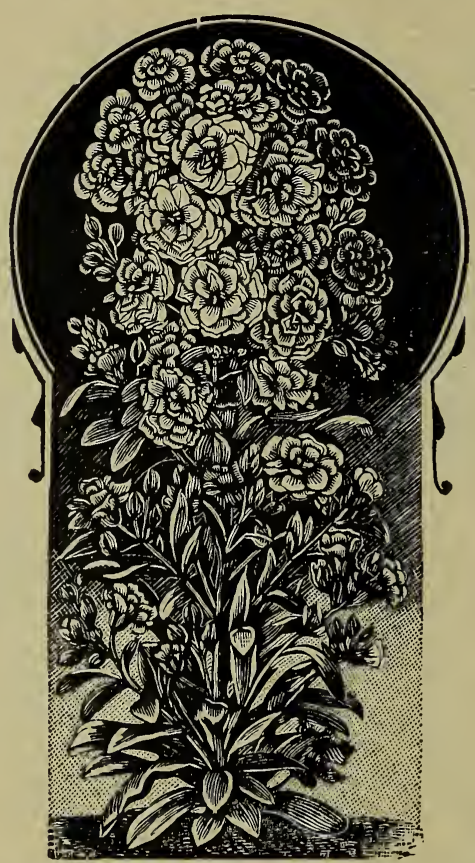

WHITE PERPETUAL STOCK.

The individual flowers are uncommonly large, of a fine rosette-like shape, and the purest possible white. If sown early will produce a great abundance of bloom from June until November. Pkt. $8 \mathrm{cts}$.

NOTHING EXGELS Than $_{\substack{\text { Thas } \\ \text { spent: }}}$ dens" as a superb autumn bloomer.

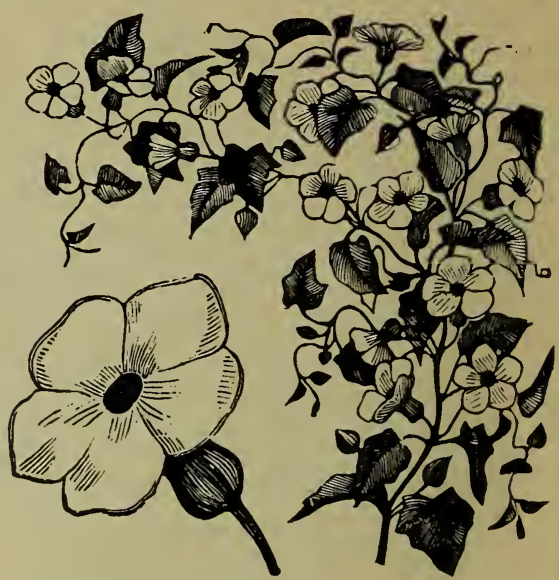

THUNBERGIA.

(BLACK-EYED SUSAN.)

Very elegant, slender-growing climbers, rapidly covering wire trellises, and also useful for vases in the garden or house. They can also be grown without support and one plant will form a beautiful mat three to four feet in diameter. The flowers are very beautiful and produced in great abundance. The colors are pure white, light yellow and deep orange, and of each color there is a variety with white eye and also witl black eye. They continue in flower all summer. Mixed. Pkt. 3 cts.

\section{GOOD AND TRUE.}

Miss Kate w. Meredith, Coates Va., writes:-I was very much pleased with your seed last year, they were all good and true to name. I am happy to be able to speak a good word for you among my friends. 


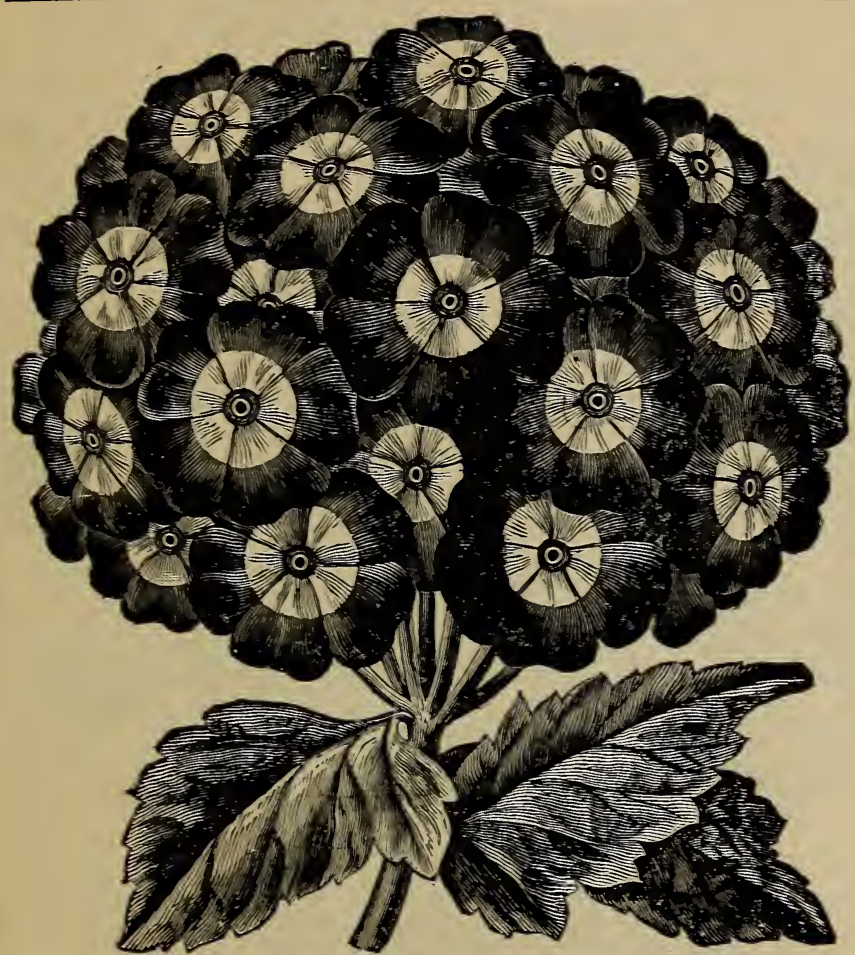

MAMMOTH VERBENA.

Flowers of unusual size, single flowers sometimes being as large as a twenty-five-cent piece, while the clusters of bloom are magnificent, and the range of color more varied than in any other mixture. For garden beds or massing the veriena is unrivaled: flowers of the most brilliant colors, blooming continually from spring until late in the autumn. Although perennials, they form luxurant plants and bloom profusely the first season from seed. Pkt. 6 cts.

\section{LEMON VERBENA.}

This elegant, fragrant plant is easily grown from seed and succeeds well anywhere. Have a good bed of it in the garden over summer, that you can cut its fragrant foliage and flowers to make up with bouquets. Pkt. 6 cts.

PURE

WHITE VERBENA. (CANDIDISSIMA.)

A fine strain of large flowering, pure white $\mathrm{Hy}$ brid Verbena, trusses large and borne freely at all times; always comes true from seed. Pkt. 6 cts.

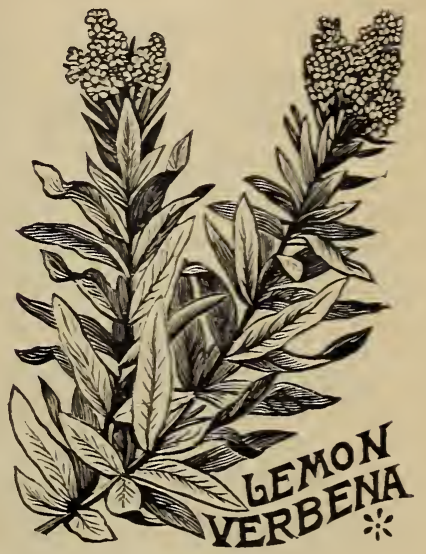

VERBENA HYBRID.

Fine mixed from a splendid range of colors. Pkt. $3 \mathrm{c}$.

VERBENA ODORATA.

This lorely Verbena is hardy, and seed may be sown in the open ground early in the spring, where they will quickly germinate, grow rapidly, and in a few weelss be in bloom and gire a profusion of beautiful blossoms all summer. The blossoms, instead of being in clusters, run up into spikes three to four inches long and is very sweet scented. No garden flower is easier grown, for it is sure to thrive anywhere. Pkt. 3 cts.

E. PTI My aim is QUALITY, HIGH GRADE O and FULL VALUE.

1:017 $72,000 \mathrm{cash}$ orders receired for my DU Seeds last season.

FH0 RE strains of all the old-fashioned and GHU1GE most popular Flower seeds.

T. 1 and TESTED, satisfactory in 4 States and Territories as well as Canada. SEEDS that are guaranteed to grow and sire 


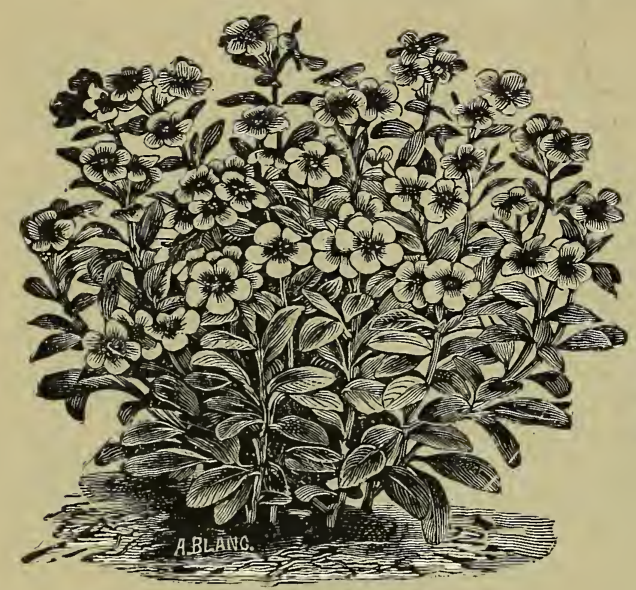

VINCA ROSEA.

A free flowering perennial, with glossy green foliage and beautiful circular flowers of a fine rose color. If sown early under glass and transplanted in a warm situation, will bloom in the summer and autumn, and may be potted for the house before frost. Pkt. 3 cts.

\section{VIOLET (VIOLA).}

The Violet should not be wanting in any garden, on account of its fragrance and early appearance. A single flower will perfume a whole room. Succeeds best in a shady, sheltered place, and can be easily increased by dividing the roots. Finest mixed. Pkt. $4 \mathrm{cts}$.

\section{DOUBLE LILLIPUT ZINNIAS.}

Dwarf, compact bushes, bearing very sma11, perfectly double pompon-shaped flowers of the brightest colors, which cover the plants during the entire summer and until frost sets in. The flowers embrace a wide range of both light and dark colors, evenly distributed. Pkt. 6c.

ZINNIA-choice double mixed. Pkt. $3 \mathrm{cts}$.

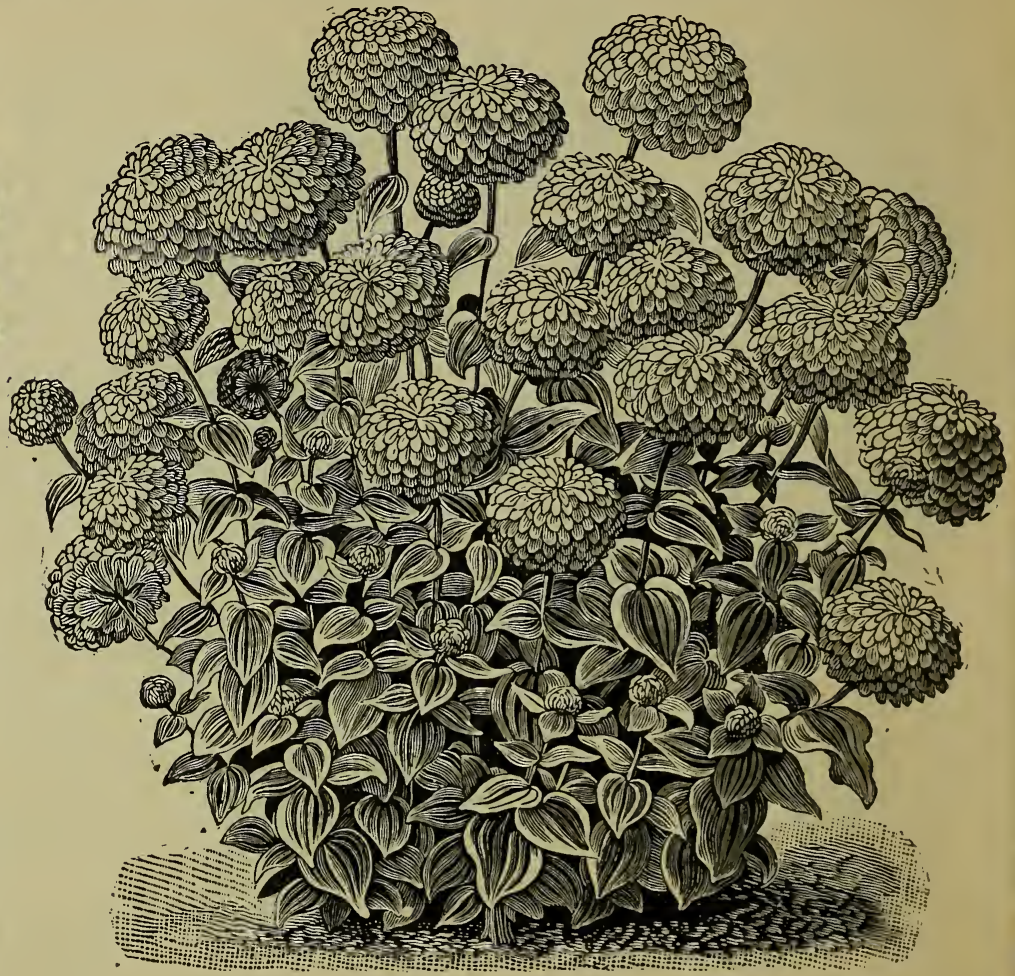

GIANT ZINNIAS.

A new class of Zinnias, giant in size and perfectly double flowers of the richest and most varied colors and shades. The plants grow about three feet high and bloom freely during a long period, making it particularly valuable for large groups. Pkt. 6 cts. 


\section{WATER LILIES.}

Many persons have been deterred from attempting the culture of water plants by the idea that a special greenhouse and tank must be built for their accommodationtrue, the various varieties may be had in flower almost all the year round in such a structure, yet they can be grown with equal success out-of-doors in ponds or streams of shallow water having muddy bottoms, or in aquariums, tubs or tanks in the house.

\section{AMERICAN LOTUS.}

\section{(NELUMBIUM LUTEUM.)}

The flowers, which are bright sulphur yellow, measure from six to ten inches across, and are delicately perfumed. Pkt. 8 cts

\section{NYMPH $A$ EA ODORATA:}

The flowers are a beautiful waxy white, with long green stems; very fragrant. Pkt. 6 cts.

\section{A WILD FLOWER GARDEN. (CHOICE MIXED FLOWER SEEDS.)}

A mixture of many varieties of beautiful, easy growing flowers, producing a constant and varied bloom the whole season, and is especially suited for those who wish only a few seeds each of the leading varieties, or a much more extensive collection than their means will permit. In no other manner can so many seeds be obtained for such a small cost. Pkt. 6 cts.; 0z. 16 cts.

\section{WAS UNFORTUNATE.}

Julia R. Ways, Porters, Md., writes:-I was unfortunate with the seeds bought from Joullast year. I sowed them all in boxes and they came up beauti. fully, but were all destroyed by a hail-storm we had in the early spring. The only plant to survive was the Phlox, and from the beauty of its bloom I could form some idea of my loss in the destruction of the others. I shall be more careful this year and not plant all my seed at once.

\section{VERY BEAUTIFUL.}

Sallje G. Cook, Leesburgh, Ga., writes:-Your flowers are very beautiful. I grew many varieties last season from your seeds.
The original signification of a lawn was a bit of unin the depth of a wood. It is now reproduced on almost every spot of ground surrounding our city homes, to heighten the landscape effects and to add a new charm and dignity to the residence; and is one of the most attractive and fascinating features in landscape gardening. THAT YOUR LAWN is not particularly ornamental in its present garb, is no reason for becoming lax in its care and management.

\section{A BEFUTIFUL LAWW,}

With its close velvety turf, is a most essential feature in the adornment of all suburban homes - without it the finest flowering plants and beciling seem insignificant, while with it, handsome grounds are assured, even with no other adornment. About April 1st is the best time to make a lawn.

LAMN GRASS SEED. Finest quality, postpaid; or, 15 cents per quart, not postpaid.

\section{AGREEABLY SURPRISED.}

Mrs. May Smolk, Binghamton, Wis., writes:-The Bargain Collection I received last year proved very satisfactory. In fact. I was agreeably surprised at the size and beanty of all. ITe had seed from four different seed houses, but yours surpassed them all.

\section{SUCH THRIFTY FLOWERS.}

Annie C. McDonald, Ironton, Mich., writes:-I sent to you last season for seeds, and must tell you they gave the greatest satisfaction. I wish you could have seen my yard-every one exclaimed-such thrifty flowers - "Do save me some seed!!"

\section{GOOD SUCCESS.}

Mrs, Walter Woolever, Arkport, N. Y., writes:-I had good success with Flower Seeds sent'me last spring. 


This
Collection
will

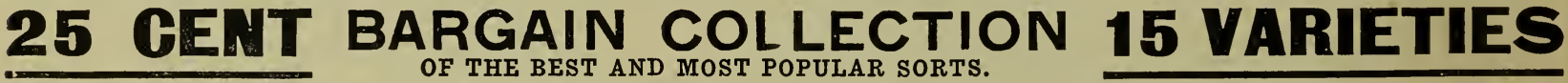

ALYSSUM, Little Gem; ASTER, Perfection Mixed; CANNA, New Dwarf French; CANDYTUFT, Snow Queen; CARNTATION, Marguerite; COBGA, Scandens; COSMOS, Mixed; DIANTHUS, Double Mixed; MIGNONETTE, Giant Red; NASTURTIUMS, Best Mixed; PANSY, Imperial German; PHLOX DRUMMONDII, Grandiflora; POPPY, The Shirley; SWEET PEAS, Eckford's Mixed, and LEMON VERBENA.

Why give 25 cents for a single plant that will bear only half-a=dozen flowers in a season, when the same 25 cents will buy Seeds sufficient to plant your garden.

The price at which $I$ offer this complete assortment (15 Varieties for 25 cts.,) places it within the reach of everyone. POSITIVELY NO CHANGES ALLOWED, OR TO BE SELECTED AS PREMIUM.

G ER. F For a Ciub of Six (Price \$1.25) l will send one Collec- Gla L tion FREE, making 7 Collections for \$1.25. 


\section{What Patrons in 44 States and Territories, including Canada, Say about my Seeds.}

8sule Bntetntrer. Advilie P O. Writes:

-I waa well pleased with the Seeds I Lida 7 . Eldriage. 500 Rhode Island

St.. Lawrence. writes. - My order of
Flower seeds last year was exceeding.

ARKANSAS

Miss Cols Gannon. Dana P. O., writes: -The fowers from the

CALIFORNIA.

Mrs.J M sehnlthele. $6+$ Penussivania are.. East 8 ants Craz, writes:-I bought were the best seeds I ever bought aoy. where. COLORADO.

Mrs. Geo. E Smlth. Longmont, w rites -The Seeds I ordered of you last year. CONNECTICUT.

Mra E. P. Clark. 8tonlngton, writes :1 was very much pleased with your OELAWARE.

Mrs. Amanda 8ipple. Frederles. writes:-I had sour Seeds last yea
snd was much pleased with them. FLORIOA.

Emma A. Thomas, Micanopy, writes:Emma A. Thomas. Mricanopy. Writes:-
1 love to see a woman brave enough to atart io aoy husidess for herself. and
certainly wish you every success in certainly wish you e

GEORGIA.

E. B. Underwood. Cash P. O., writes:S liked the Flower Seeds bought of you
lagt spring very much. 1ОАн०.

Mru. A. Jase Williams, 1311 Jefferson eve., Bolse city. writes. - I raised some beautiful Dowers from the ILLINOIS

Mrs. Ellan stearne, 219 Beach St. ABrora. writes:-I received Seeds from you with them.

\section{INOIANA.}

Emme Vall, Benton P. O. writes:Yoar Seeds were of the best quality last jear and the cheapest 1 have ever you the very best of success.

INOIAN TERRITOAY.

Mrs. -The Seeds I had from you last year - were perfectly satisfactory. I wish you

whe B Bazen Weat Point, writes: $-I$ waot to tell you that the collection of Yhower Seeds we received from you last yoo yoccess in your businese.

KENTUCKY.

Mary C. Lovell, Paris, writes: $-I$ was rery much pleased with the flowera LOUISIANA.

Mrs. E. P. Oatis, cor Robert and Dry. - des Sis. New Orleans, writes-I had some Seeds from you last year that
pleased me rery much. I odmire your Dere

MAINE.

Mrs. C. A. Campbell, Gouldeboro. writes : - I was very much pleased with.

\section{MARYLANO.}

miss A. Grunwell, Orbana, writes:The Seeds I received last spring were
very satisfactory. I wish you a suc rery satisfactor
cessful yea

\section{MASSACHUSETTS.}

Mrs. C. H. shepard, 12 Church St., Wakessid. writes:-I tried your Seede last seas
factory.

Michigan

Mrs. A. E. Elder. Mancelona, writes:I had some of your Seeds last year and MINNESOTA.

Mrs. A. A. Van Gorson, Mentor P. O. writes:-I had Seede from you last year
and know you are reliahle. Wishiog you abuodant success. .

MISSISSIPPI.

Bettie E. Harig. Bellefontalns, orites:
-1 was well pleased with the Flower Seeds ordered from you lo st year. I wish you great success.

MISSOURI.

Mrs. C. Andriano. 2506 Fred ave., Bi. Jossph. Writes: - I have beeo much from you last year, and can recom mead same to my friends.

MONTANA.

Kary Herhold. Shordan. writes: had good luck with oll the Seeds NEBRASKA.

Misa Bethine Hackey. Cedar Rapils. writes:-I was very much pleased with yon ouccess in your wodertaklog.
THE OTHER SIDE OF THE QUESTION.

Two Fac-simile Letters from dissatisfied customers, selected from less than a dozen received this season, to whom I returned the amount paid for Seeds.

$$
\text { Guby } 211896
$$$$
\text { Madam }
$$

Nleaced wits mas mat mestor ued as they did matgrov todo any good matimene than flue camenf on any it all gneve mase theace nefund the amount paid for them 12 cente

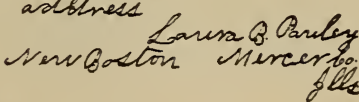

Hewen $t \&$ gin 15198

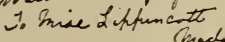

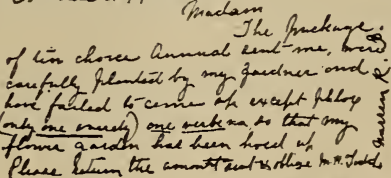

\section{DO NOT CLAIM}

That everyone can grow $\mathrm{my}$ seeds, but they will, and do grow, (with proper treatment and favorable circumstance-s) all reasonable persons expect and $I$ can better afford to have the good will of the unreasonable occasional failure, than to retain their money. My guarantee is good.

$$
\text { adtereses }
$$

\section{NEW HAMPSHIRE.}

Iir. G. B. Chese, Winchenter, writes. -The Seeds bonkht of you last yea: one Pansy hinssom that measured 2 ? admired. NEW JERSEY.

Mrr. BAMG $J$. ROB, Walpeck Centre. writes:-I had some of your Seeda las year, and they were jus
ing you grand success.

NEW YORK.

Gertrude El wood, starkolle, writes. -I was rery much pleased with your Seeds last year, and could hardly see how you coold send su
for such a small $p$ rice.

NORTH CAROLINA.

Mise Mitule Y. Ell1s, Ralelgh. writes - Flower seeds and it ave enection of

faction. NORTH DAKOTA.

Mrs. Isasc Marr. Crary P. O.. writes were good. OHIO.

Mrs. I. Bloeker. III N. Howard St. Akron, writes. - Had splendid success with Verbenas.

OKLAMOMA.

Mrs. B. C. Bess, sheridan, writes:Last year $\mathrm{I} \mathrm{sq} w$ your advertisement and sent for the collection offered, and Irith sa koow they are good. I wish you all the success possible.

\section{OREGON.}

Mrs. Mary Leslie, P1 sasant Bome. writes:-I cannot refrain from woudering at the cheapness of your Seeds. tty -for I vever sa their kind, and more especisuly the Aaters; they were perfect beauties. PENNSYLVANIA. Mrs. L. J. Whippo. New Castle, writest
What canuot a woman do? May yon AHODE ISLANO.

Mrs. Hulda B. Greene, Coventry Cen. ble reports of your Seeds from those ho have had them.

SOUTH CAMOLINA.

8. Ora Ford, Wallins P. O. Writes:-
$t$ an very much Deased with your

Eeeds. SOUTH OAKOTA.

Mre. L. B. Banteo, Forertbure. Writes: I bought Seeds of you lest spring thest

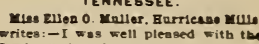
writes: - I was well pleased with the TExas.

Mrs. W. A. Brambagh. Tsrrell, writes A friend sent me your 12 cent collectlo: of your Seeds. Wishing you much suc. CeBs. VERMONT

Mrs. L. W. Eddy, Marshasid. WHtes:I send for more of your seeds. as those I VIRGINIA

Urs. A. M. Grag. North woot, writes:I bought Flower Seeds from you last year and was pleased with them. Wish. ing you wuch acces. WASMINGTON.

Mrs. Mary Lasuch, Eiberton, writes:Keceived some of your Flower Seeds isfactioo.

WEST VIRGINIA.

Lonle I. Gibson. Mi. Ids, writes:-I wa so well plessed with your 12 cent collecthoo last year. I will give you my order cess. WISCONSIN Mrs. Jave A Esllenbeck. Best. P. O. rites: - I was much pleased with your
Seeds last year. I wish you muct success.

E. B. ManitoBa.

E. H. O. O. Eay. Portage in Prairlo.

CELleot. CANADA

Miss Adslles Desilsts, Beche Coart. Pr. Qnebec, writes:- Your seede of
st year have given satiofactlon.

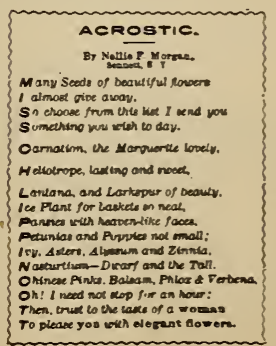




\section{MADAME CAROLINE TESTOUT ROSE.}

This popular new Rose has attracted more attention than any rose sent out since the American Beauty. It is a Hybrid Tea, with a decided though delicate tea fragrance. Flowers large, double, and globular. In color it is simply unequalled among PINK roses, being of a wonderfully CLEAR BRILLIANT PINK, of one solid tone witliout shading of any kind. It also has good points besides color; it is a remarkably free bloomer, strong in growth, fine foliage and large size. It needs no special treatment; and for a high-class Rose of easy culture, it is certainly unequalled. ONE STRONG HEALTHY PLANT FROII A 21/2-INCH POT, WELL ROOTED, FREE WITH EVERY ORDER FOR SEEDS IN PACKETS FROM THIS CATALOGUE AIMUNTING TO $\$ 1.00$.

\section{GRAND HYBRID TEA ROSE METEOR.}

The brightest colored and most brilliant Rose; recommended for bedding and general planting, as well as for growing in pots and conservatory. The color is RICH VELVETY CRIMSON, exceedingly bright and striking, and both buds and flowers are large and elegantly formed, fully double, and borne on nice long stems, which renders it especially attractive, as well as nice for cutting. It is a vigorous and healthy grower and a quick and constant bloomer, quite fragrant; a really excellent Rose in every way, and never fails to please. ONE STRONG HEALTHY PLANT FROM A $2 \frac{1}{2}$-INCH POT, WELL ROOTED, FREE WITH EVERY ORDER FOR SEEDS IN PACKETS FROM THIS CATALOGUE AMOUNTING TO 50 CENTS.

\section{On all orders for Seeds in packets to the amount of $\$ 1.30$, I send one of each variety.}

\section{ONIS ONLY TWO ROSES WILL BE SENT TO ANY ONE PERSON.}

\footnotetext{
CPE NII NTIC So many of my customers have requested me to supply them a good Rose, that C 10110101 I determined to select two of the best known varieties of late introduction, from my 1894 Catalogue. I DO NOT SELL PLANTS--but I love to surprise and astonish my friends with a BARGAIN OFFER each season, and at the same time accommodate those wishing a good, strong, healthy Rose plant, that will give satisfaction in every particular. I would also state, that I paid 25 cents each for all my stock plauts of "Madame Testout" to propagate from, and with good luck will have 10,000 plants of the two varieties to give arvay to my patrons in 1894. Send your order early, before the supply is exhausted.
} 
ALL SEED Sent postpaid and safe arrival guaranteed. I also warrant my seeds to grow, that is, with proper treatment and favorable circumstances, and will cheerfully refund the price paid, or refill the order to any customer who is not satisfied.

HOY TO REFIT MONEY Send by Post Office, or Express Money Order, Drafts or Registered Po 1 letters. When not convenient to send by any of these methods, send Postage Stamps, which $I$ receive the same as cash in any amounts.

GEF PRE To those who do not wish the Premium Roses, I allow 15 cents worth extra to be SEED selected, on all orders from this catalogue to the amount of 50 cents or upwards, but please Remember, this applies to Seeds in packets oniy, and cannot be allowed on an order for seed by the ounce, $1 / 4 \mathrm{l}$. and pound, collections, Lawn Grass seed, Plant Food or Implements.

FLORISTS Who purchase in Trade Packets and Bulk, will please send for free copy of my Wholesale Trade List. It will save you money.

0UISTI0NS Amateurs and others who wish fuller instructions on cultivation, or varieties best suited for ULS: UNS house or out-door culture, or any other information will be cheerfully answered at all times (even in the busy season), providing you enclose stamp for reply.

THE TESTIRONALS Throughout my catalogue are Bona Fide; and unsolicited, with name and

\section{Be sure and write your full address, and write it plainly.}

$$
\begin{aligned}
& \text { Alay the } 109 \text { : } \\
& \text { Saifield Soma }
\end{aligned}
$$

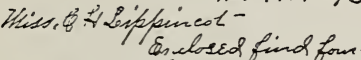

$$
\begin{aligned}
& \text { tim sent Est for which send one }
\end{aligned}
$$

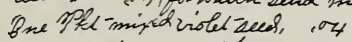

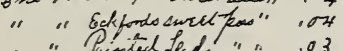

$$
\begin{aligned}
& \text { " "Phinied foadt" " } 203 \\
& \text { Horunt Dlesent fokenaylsiss, } \\
& \text { bernaden bherry Pht } 4 \text { ot } \\
& \text { Partictaca doble Heand } \\
& \text {-ce flant } \\
& \text { the brailing fuschar } \\
& \text { dablia donble } \\
& \begin{array}{l}
\text { Hers fharles E } \\
\text { Bor } 23 y
\end{array}
\end{aligned}
$$

business, a great many letters that are deficient in the address of the writer. (See Photo. fac-simile letters above). Some are unsigned, in some no post office is given;

and in others both name and post office are omitted. The best I can do with such a letter is to file it away and wait for a complaint from the sender, and often, the same mistake or omission is repeated in the letter of complaint. I have many letters of this description and would be glad to fill the orders if $I \mathrm{knew}$ the addresses of the senders.

\section{MISS C. H. LIPPINCOTT, 319 and 323 Sixth Street S.,} MINNEAPOLIS, MINN. 


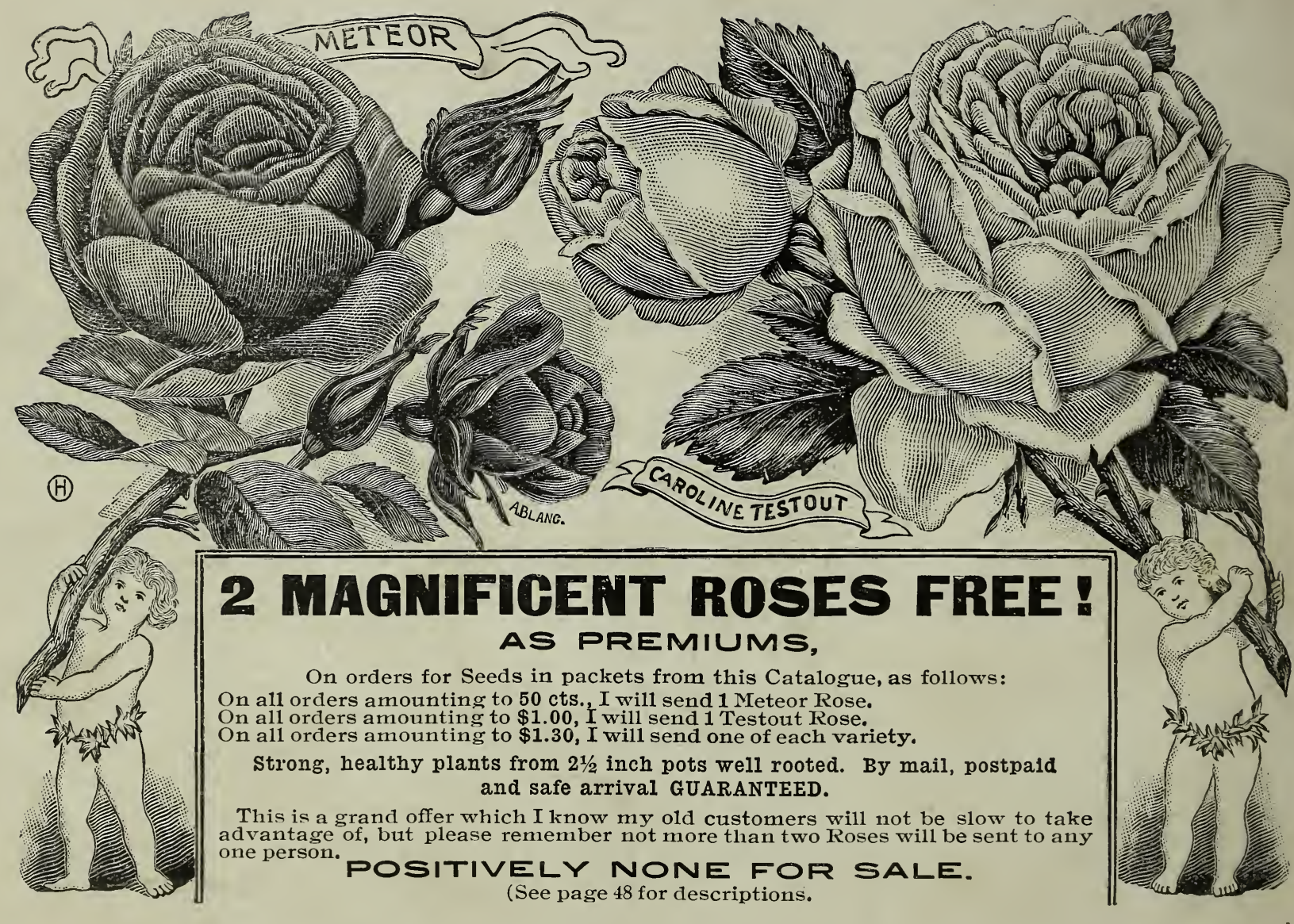

